\title{
MÉTODO DE COLORAÇÃO DO XILEMA, PELO FLUXO TRANSPIRATÓRIO, APLICADO NA DETERMINAÇÃO DE INFECÇÃO DO RAQUITISMO DA SOQUEIRA EM CANA-DE-AÇÚCAR
}

\author{
PAULO ROBERTO RIBEIRO CHAGAS \\ Engenheiro Agrônomo
}

Orientador: Prof. Dr. HASIME TOKESHI

Dissertação apresentada à Escola
Superior de Agricultura "Luiz de
Queiroz", da Universidade de São
Paulo, para obtenção do título de
Mestre em Agronomia, Área de
concentração: Fitopatologia.

PIRACICABA

Estado de São Paulo - Brasil

Abril - 1986 


$$
\begin{aligned}
& \text { Ao meu pai e meus sogros (in memorian) } \\
& \qquad \overline{\text { minha mãe }} \\
& \text { minha homenagem }
\end{aligned}
$$

A minha esposa Sōnia Regina Aos meus filhos Fabrício, Fabiano e Paula Regina 


\section{AGRADECIMENTOS}

A Esposa Sōnia Régina Venãncio Chagas, pela dedicação, incen tivo e sacrificio durante o desenvolvimento do presente trá balho.

Ao Professor Dr. Hasine Tokeshi, pela eficiente orientação, a poio, valiosas sugestôes e estímulo constante; a ele, espo sa e filhos, pela amizade.

Ao Programa Nacional de Melhoramento da Cana-de-Açūcar, IAA/ PLANALSUCAR, pela possibilidade do treinamento.

Ao Engo Agro James Pimentel Santos, Superintendente Geral do IAA/PLANALSUCAR, pelo incentivo e apoio; a ele esposa e fi lhos pela amizade e convivio.

Aos Supervisores de Melhoramento Centro-Sul, Dr. Sizuo Matsuoka e Engo Agro Antonio Lazarini Segalla, pelo apoio, suges tões e amizade.

A Coordenadoria Regional Leste, e em especial ao Eng? Agr? Carlos Alberto Barbosa Zacarias, pelo apoio, solidariedade e amizade.

A Seção de Melhoramento da Coordenadoria Regional Sul do IAA' PLANALSUCAR, pela excelente colaboração no fornecimento de material.

A Usina da Barra S/A, em especial ao Engo Agru Massahiro Nagumo, pela excelente colaboração no fornecimento de mudas, para o desenvolvimento do presente trabalho. 
A Estação Experimental de Piracicaba, pela excelente contribuição no desenvolvimento do presente trabalho, pelo forne. cimento de mudas.

A Ailton José, Vera Lūcia, clāudia Márcia, Maria da Gıōria, - Venício Arújo, Eunicie Maria pelo inesgotável apoio, carinho e amizade dispensados durante o curso.

Aos meus irmãos, cunhado, cunhadas pela amizade e consideraçăo.

Ao Engọ Agrọ Aldo Alves Peixoto, pelo incentivo, apoio e amizade.

Ao Engọ Agrọ Norberto Antonio Lavorenti, pelas sugestões e co laboraçōes nas anālises estatísticas.

Ao Sr. José do Nascimento Rodriques de Abreu e Sra. Guida Maria Correia Pinto de Abreu pelo apoio, amizade, considera ção e convĩvio.

Aos Colegas do curso e em especial aos Eng?s Agrọs Hermann Pa 1 o Hoffmann, Rēne de Assis Sordi e Wagner Bettiol, pelatro ca de idéias e excelente convĩvio mantido durante o curso.

Aos Professores do Departamento de Fitopatologia da ESALQ, pelos valiosos ensinamentos.

As Secretārias Maria do Carmo Maluli Delgado, Vera Lúcia de 0 I iveira e Aparecida de Fātima Gonçalves Ferraz de Campos, pe los valiosos trabalhos de datilografia durante o curso e tradução do resumo para o Ing̣ és.

A Bibliotecāria Maria Aparecida Remédio, peía colaboração da correção da 1 iteratura citada. 
iv.

Aos Funcionarios do Departamento de Fitopatologia da ESALQ, pe la colaboraçäo nos trabalhos de campo e laboratório.

Aos Motoristas da superintendência Geral do IAA/PLANALSUCAR, João, Messias e Alício, pelo apoio, consideração e amizade dispensado durante o curso.

Ao Desenhista Hëlio 0liveira Junior, pela colaboração nos denhos apresentados. 


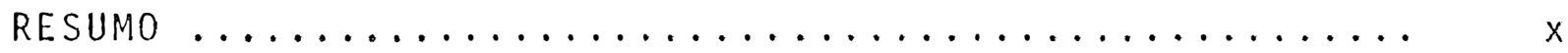

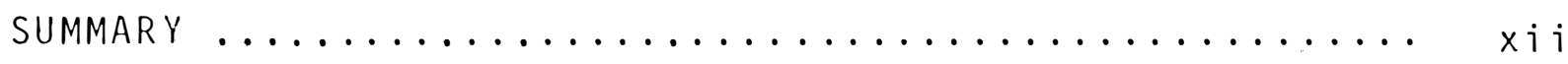

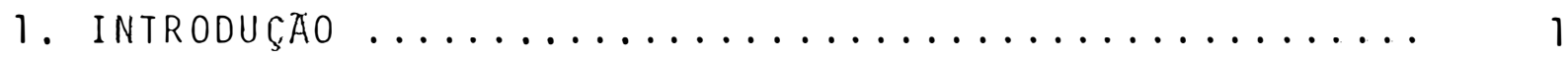

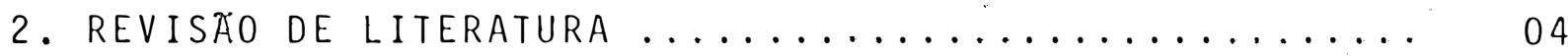

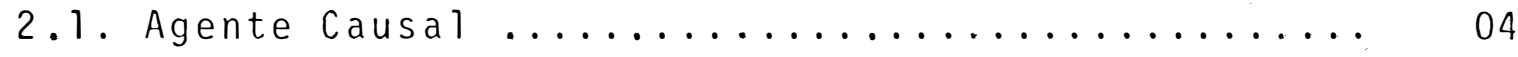

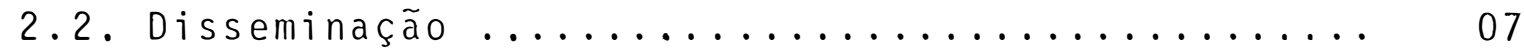

2.3. Diagnose da Doença ...................... 09

2.3.1. Fatores que Interferem na Expressão dos

Sintomas ......................... 09

2.3.2. Reprodução de Sintomas na Diagnose da Doença .......................... 11

2.3.3. Diagnose atravēs de Testes Químicos e Bi. 1ögicos ........................ 12

2,3.4. Testes Serológicos na Diagnose da Doença. 13

2.3.5. Diagnose através da Microscopia......... 14

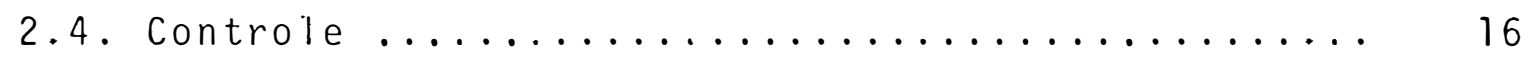

2.4.1. Plantio de Material Sadio ............ 18

a) Tratamento térmico com água quente ... 19

b) Tratamento à vapor ....................... 22

c) Tratamento com ar quente ........... 23

2.5. Movimento de Agua na Planta e Função da Anatomia Vascular na Resistēncia ao RS ............... 24

2.6. Medidas da Intensidade de Doença pela Observação Visual ........................... 27

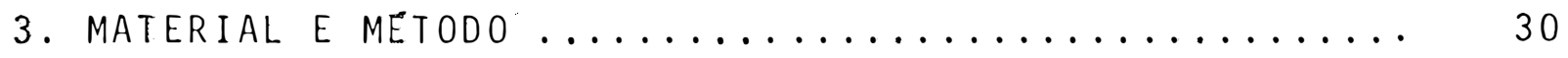

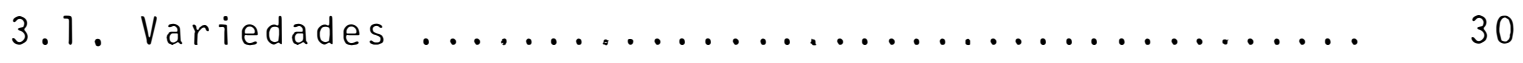

3.2. Obtenção do Inóculo e Inoculação ................ 31

3.3. Soluções Corante e Diluições ................. 31

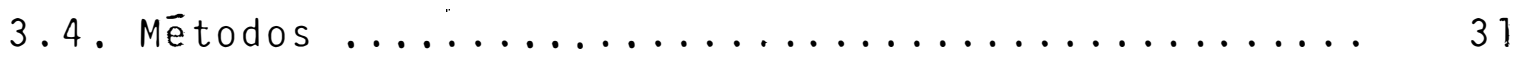


3.4.1. Método de Vazão de Kgua em Colmos de Cana-de-Açūcar ....................... 31

3.4.2. Método de Vazão de Solução Corante ..... 32 3.4.2.1. Padronização da Escala de Sintomas do RS, pela Coloração do Xi-

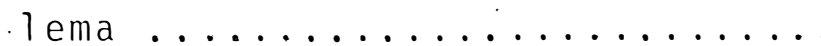

3.4.2.2. Tempo Mĩnimo Necessārio na Coloração do Xilema, pelo Método de Vazão de Solução Corante .......

3.4.3. Método de Coloração do Xilema pelo Fluxo

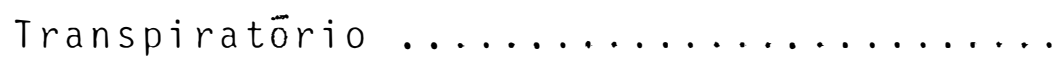

3.5. Fatores que Interferem no Método de Coloração do Xilema, pelo Fluxo Transpiratōrio ............ 34 3.5.1. Altura de Recorte do Colmo ........... 35

3.5.2. Hora de Corte da Muda .............. 35

3.5.3. Tempo de Cavitação ............... 35

3.5 .4 . Corantes ...................... 36

3.5.5: Tempo de Coloração do Xilema .......... 36

3.5.6. Interferēncia de Brocas (Diathaea spp).. 36

3.5.7. Umidade do Solo ................. 37

3.6. Avaliação da Eficiência dos Três Métodos na Determinação de Sanidade de Colmos Tratados Termicamente (TT) e inoculados com Caldo Bruto (RS).

3.6.1. Determinação da Vazão de Figua em Colmos

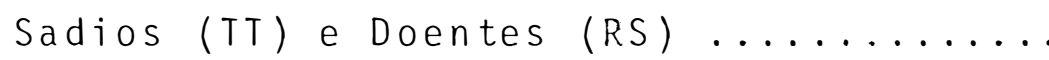

3.6.2. Determinação da Percentagem Média de Vasos Coloridos, pelo Método de Vazão de So

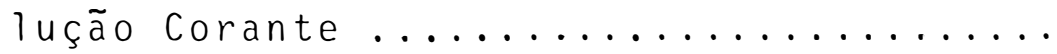

3.6.3. Determinação da Percentagem Média de Vasos,Coloridos, pelo Método de Coloração do Xilema pelo Fluxo Transpiratório ........ 
3.6.4. Comparação entre os Métodos: Vazão de Solução Corante e do Fluxo Transpiratōrio, na Determinaçäo de Sanidade de Colmos Sa-

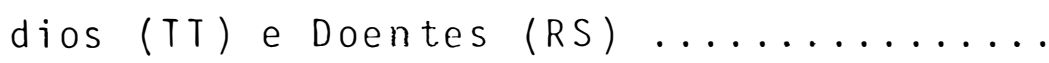

3.7. Aplicação do Método de Coloração do Xilema pelo Fluxo Transpiratório, no Controle de Qualidade de Viveiros e Canaviais Comerciais de Cana-de-Açü -

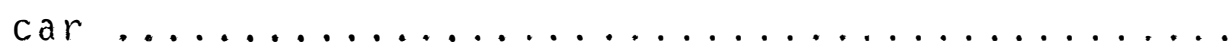

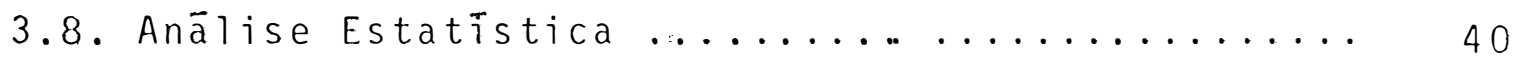

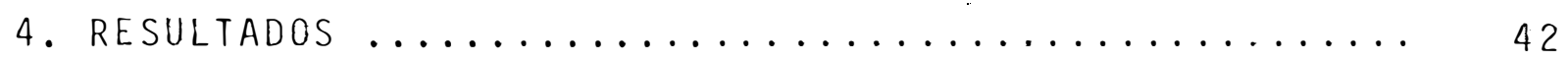

4.1. Padronização da Escala de Sintomas do RS, pela

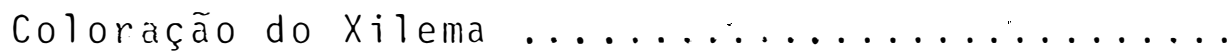

4.2. Tempo Mínimo Necessário na Coloração do Xilema pelo Método de Vazão de Solução Corante .........

4.3. Fatores que Interferem no Método de Coloração do Xilema pelo Fluxo Transpiratório ............ 45

4.3.1. Altura de Recorte do Colmo ............ 45

4.3.2. Hora de Corte da Muda .............. 47

4.3 .3 . Tempo de Cavitação ............... 50

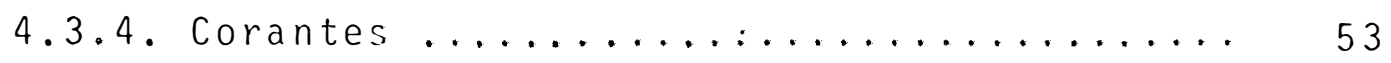

4.3.5. Tempo de Coloração do Xilema ........... 59

4.3.6. Ataque de Broca (Diatraea spp) ......... 62

4.4. Avaliação da Eficiēncia dos Trés Métodos na Determinação de Sanidade de Colmos Tratados Termi camente (TT) e Inoculados com Caldo Bruto (RS).

4.4.1. Determinação da Vazão de Āgua em Colmos Sa dios (TT) e Doentes. (RS) ............... 64

4.4.2. Determinação da Percentagem Média de Vasos Coloridos, pelo Método de Vazão de So

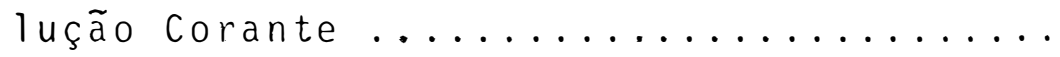

4.4.3. Determinação da Percentagem Média de Vasos Coloridos, pelo Método de Coloração do xilema pelo Fluxo Transpiratōrio ....... 
Pàg.

4.4.4. Comparação entre os Métodos: Vazão de Solução Corante e do Fluxo Transpiratóriona Determinaçäo de Sanidade de Colmos Sadios

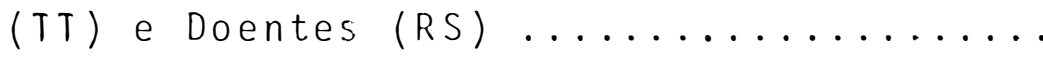

4.5. Aplicação do Método de Coloração do Xilema pelo Fluxo Transpiratório, no Controle de Qualidade de Viveiros e Canaviais Comerciais de Cana-de-A-

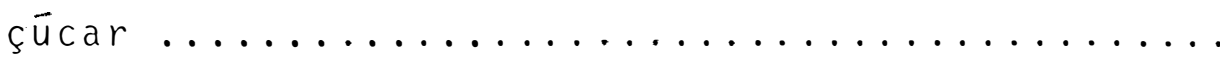

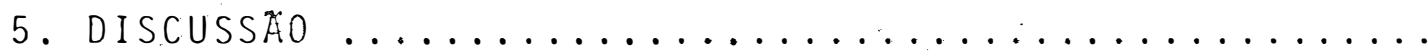

77

80

5.1. Padronização da Escala de Sintomas do RS, pela co

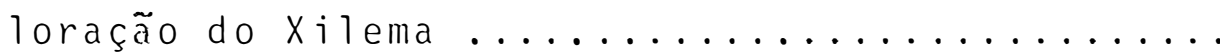

5.2. Tempo Mĩnimo Necessārio na Coloraçäo do Xilema, pelo Método de Vazão de Solução Corante ........

5.3. Fatores que Interferem no Método de Coloraçä́o do

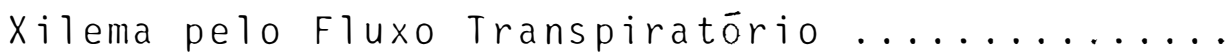

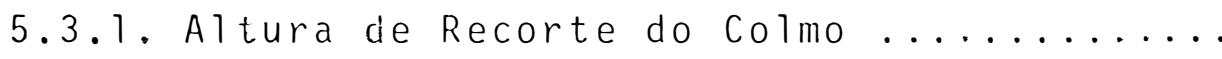

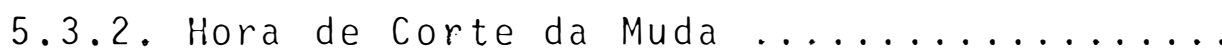

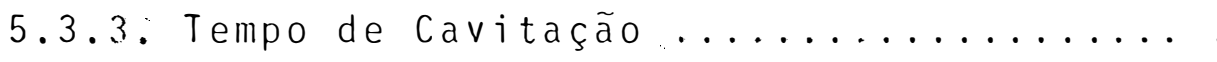

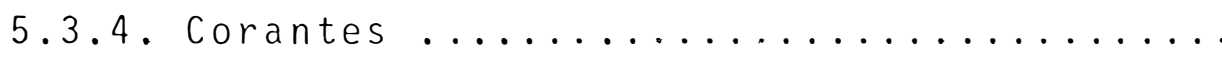

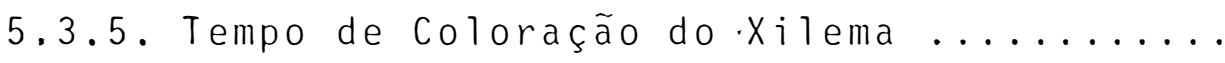

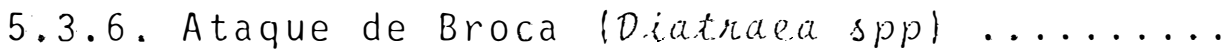

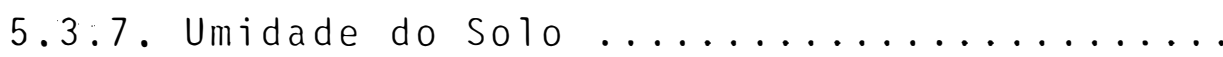

5.4. Avaliação da Eficiēncia dos Trēs Métodos, na Determinação de Sanidade de Colmos Tratados Termicamente (TT) E Inoculados com Caldo Bruto (RS).

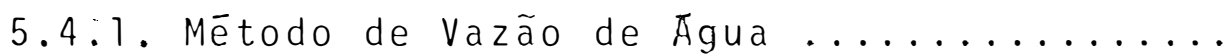
5.4.2. Método de Vazão de Solução Corante ...... 5.4.3. Método de Coloração do Xilema pelo Fluxo Transpiratório ................... 90

5.4.4. Comparação entre os Métodos: Vazão de So90 lução Corante e do Fluxo Transpiratöriora

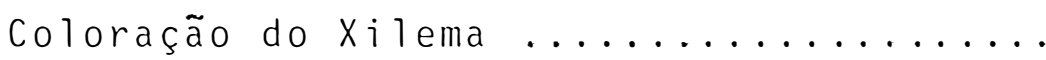


Pàg.

5.5. Aplicação do Método de Coloração do Xilema pelo Fluxo Transpiratório, no Controle de Qualidadede Viveiros e Canaviais Comerciais de Cana-de-Açú -

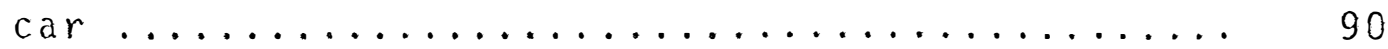

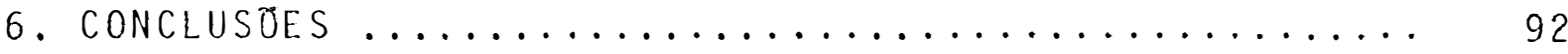

7. LITERATURA CITADA ....................... 94

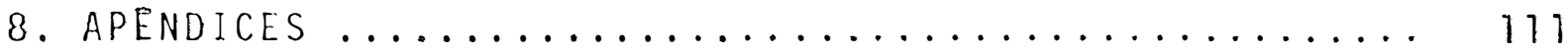


METODO DE COLORAÇAOO DO XILEMA, PELO FLUXO TRANSPIRATORIO, APLICADO NA DETERMINAÇAO DE INFECÇAO DO RAQUITISMO DA SOQUEIRA EM CANA-DE -AÇOCAR

\author{
Autor: PAULO ROBERTO RIBEIRO CHAGAS \\ Orientador: Prof. Dr. HASIME TOKESHI
}

\title{
RESUMO
}

o trabalho teve como objetivo desenvolver um mé todo simples de avaliação dos nîveis de contaminação do Raqui tismo da Soqueira em viveiros e canaviais comerciais. 0 método foi baseado na determinação da condutividade de água pelos vasos do xilema no colmo de cana-de-açūcar. A condutivida de foi medida pela sucção da solução corante através de meios naturais de tensão do fluxo transpiratório.

0 teste de coloração foi feito comparando colmos adultos obtidos a partir de viveiros aparentemente sadios (canas tratadas termicamente - 50,50 C/2 horas) e colmos obti dos de viveiros doentes (inoculados com caldo bruto - RS). Pa ra isto, a extremidade basal de colmos inteiros das variedades CB 41-76 e NA 56-79 foram mantidos em recipientes contendo diferentes soluçoes corantes, por 60 minutos. Feito isto, a percentagem de vasos coloridos no primeiro nó basal, foi de terminada através de uma escala de sintomas pré-estabelecida.

os resultados mostraram que a altura onde o col mo é novamente cortado, o tempo de cavitação, corantes, a hora do dia que é colhido o colmo ou usado o método, o ataque de broca (Diatraeae sppl e a umidade do solo no momento do corte do colmo, são alguns dos fatores que interferem na precisão da coloração do xilema pelo método do fluxo transpiratō rio.

o novo método foi comparado aos métodos de ava- 
liação de resistência ao raquitismo da soqueira pela vazão de água e vazão de solução corante, ambos usando a pressão de vá cuo. Os resultados mostraram que os trés métodos são equivalentes. Entretanto; o novo método mostrou ser mais preciso, mais eficiente, mais económico e mais prático do que os dois outros na determinação do indice de contaminação do raquitismo da soqueira em viveiros e canaviais comerciais. A simplici dade e ausencia de equipamentos complexos e sofisticados torna viävel seu uso por extensionistas ou mesmo por produtores para o controle de sanidade de viveiros e canaviais comerciais de cana-de-açūcar. 
.$x i j \ldots$

METHOD OF XYLEM COLORATION, BY THE AID OF THE TRANSPIRATORY

FLUX, APPLIED TO THE DETERMINATION OF

RATOON STUNTING DISEASE INFETION IN SUGARCANE

\author{
Author: PAULO ROBERTO RIBEIRO CHAGAS \\ orientador: Prof. Dr. HASIME TOKESHI
}

\title{
SUMMARY
}

The objective of this work was to develop a simple method for the evaluation of the level of contamination of commercial sugarcane nurseries by the ratoon stunting disease. The method was based on the determination of the water conductivity of the xylem vessels in the sugarcane stalks. Conductivity was measured by the sucking of a dyed solution by means of the natural transpiratory flux tension.

The dyeing test was made comparing adult stalks obtainded from apparently healty nursery (progeny of long hot water treated canes - 50,50 C/2 hours) wilth those obtained from diseased (inoculated) nursery. The basal portion of stalks of the varieties CB41-76 and NA56-79 was maintained for 60 minutes in containers with different dyeing solution. Later on, the per centage of dyed vessels in basal nodes was evaluated by the aid of a predetermined visual scale.

The results showed that the height where the stalk is cut, the cavitation period, dyes, the time of the day the stalk is collected or used to apply the method, the borer attack and the soil moisture just before the stalk is cut, are some of the factors that interfere in the precision of the xylem coloration by the aid of the transpiratory flux.

This new method was compared to the methods of $\underline{e}$ 
. xi i i.

valuation of ratoon stunting disease resistance by the water flow and the dyed solution flow, both using vacuum pressure.

The results showed that all the three methods are equivalent. Nevertheless, the new method showed to be more pre cise, more efficient, more economic and more practical than the two others in the determination of the ratoon stunting disease incidence in nurseries or cane field. The simplicity and the exemption of sophisticated and complex equipments make it viable to be used by the extensionists or even the own producers to control the sanity of the commercial sugarcane fields or nur. series. 
1. INTROUÇÃO

A importància social e económica da cultura canavieira no Brasil, cresceu com a crise energëtica mundial e a criação do Programa Nacional do Álcool (PROÁLCOOL). Para a produção no ano de $1983 / 34$ de 8,5 milhões de toneladas de açú car e 9,5 bilhões de litros de álcool, foi necessārio a ocupa ção-de 3,8 milhões de hectares de terra. A produção de 9,5 bi lhões de litros de älcool, correspondeu a uma oferta de gasolina da ordem de 50 milhöes de barris/ano, economizando para - Brasil em torno de 2 bilhões de dólares em divisas. o consu mo global de àlcool em 1984 foi da ordem de 8 bilhões de $1 j-$ tros, dos quais 6,6 bilhões foi de álcool anidro e hidratado utilizados como carburantes, possibilitando a fabricação de aproximadamente mil veículos movidos exclusivamente a älcool, a lém de toda a gasolina consumida no pais levar uma mistura de $20 \%$ de ālcool, gerando a criação de centenas de millhares de empregos indiretos. Ainda, na indūstria quĩmica foram consumi dos 600 mi ihões de litros e exportados em torno de 1 bilhão de litros, correspondendo a ingresso de divisas da ordem de 250 milhões de dólares (BERTELLI, 1985). No entanto, apesar de cifras tão elevadas, a comparar-se o potencial genético de produtividade da planta, com os recordes obtidos no Brasil e em outros países na produção de açucar, por ārea, estes são pelo menos trés vezes maiores que as 4,5 e 7,7 t/ha obtidas 
atualmente no Nordeste e em São Paulo, respectivamente (CRUZ et alii, 1985).

Entre os fatores respensáveis pela baixa produtividade agrícola e industrial da cana-de-açúcar, encontramse as doenças. Entre elas, o raquitismo da soqueira, por não apresentar sintomas específicos, é seguramente a que maiores prejuizos tem causado, pelo fato de estar presente em todos os canaviais, sem, no entanto, ser notada (HUGHES, 1958) e suas perdas oscilaram entre 10\% a 60\% (MATSUOKA, 1976 e TOKES HI, 1980). Deste modo, a disseminação do RS, que se dā através de mudas doentes e por instrumento de corte por ocasião de plantio e colheita (STEINDL e HUGHES, 1953; HUGHES e STEINDL, 1955; TODD, 1960; STEINDL, 1961; GALLI, et a $1 \mathrm{i}$;, 1968 e MATSUOKA, 1975) torna-se rāpida e eficiente, chegando o mate rial sadio após poucos cortes, a níveis altíssimos de contami nação (MATSUOKA, 1983, 1984).

Como no Brasil os métodos de melhoramento empre gados não dirigem suas seleçöes especificamente para a obtenção de variedades tolerantes ou resistentes ao RS, a ünica medida de controle da doença, recomendada é o tratamento das mudas em āgua quente a 50,50 c por 2 horas (TOKESHI, 1980; MATSUOKA, 1983 e MASUDA, 1984). Apesar dessa prática realmente proporcionar a obtenção de mudas de boa sanidade, sabe-se que a cura não é completa. (HUGHES e STEINDL, 1955 e STEINDL, 1961 ; HUGHES et alii, 1964; LOPES - ROSA e ADSUAR, 1970; MATSUOKA, 1982, 1983, 1984 e MASUDA, 1984). Näo foi desenvolvido, até o presente um meio seguro de baixo custo e de fäcil. execução para o controle de qualidade das mudas obtidas atravēs da termoterapia.

Utilizando o fluxo transpiratörio como bomba de sucção de solução corante coloriu-se os vasos do xilema para detectar falhas no tratamento térmico no controle do RS. 0 mé todo foi comparado com os mëtodos de vazão de àgua e vazão de soluçäo corante. Os resultados mostraram que o mëtodo de colo ração do xilema pelo fluxo transpiratōrio é mais simples, pre 
ciso, rāpido, econémico e prātico, na detecção de contaminação de viveiros e canaviais comerciais. Determinou-se tambēm alguns fatores que interferem na eficiēncia e eficācia do método. 
2. REVISÃO DE LITERATURA

\subsection{Agente Causal}

o Raquitismo da Soqueira foi considerado desde sua constatação na Austrália, nos anos de 1944-45, pela maio ria dos autores, como sendo doença causada por virus (STEINDL, 1950; HUGHES E STEINDL, 1955; SCHEXNAYDER, 1956, FORBES E LING, 1960, STEINDL, 1961; GILLASPIE et a 1ii, 1966; GILLASPIE, 1971; MATSUOKA, 1972) sem que o possivel virus envolvido tivesse si do isolado e caracterizado.

STEIB e TANTERA (1970) já suspeitavam da doença estar associada a um micoplasma, porém, esta suspeita foi alterada com a suposição de um complexo de dois patógenos, um virus e um micoplasma (KHURANA, 1972).

PLAVSIC - BANJAC E MARAMOROSCH (1972) revelaram a presença de corpos pleomórficos no xilema de canas maduras afetadas, semelhantes a uma pequena bactéria ou organismo do tipo micoplasma, hipótese esta, confirmada mais tarde (MARAMO ROSCH et alii, 1973; GILLASPIE et alii, 1973). Estes autores, a través de estudos em microscópio eletrónico encontraram evidências indicando estar a doença associada a uma bactéria do grupo corineforme ou organismo semelhante a ricketsia, no xilema de colmos infectados com RS, porém, não em colmos sadio de cana-de-açūcar. 
Segundo TEAKLE (1974), a pequena bactēria associada ao RS na Austrälia era possivelmente igual ao microor ganismo observado em colmos doentes de cana-de-açücar, em Por to Rico por PLAVSIC - BANJAC e MARAMOROSCH (1972), devido as semel hanças nas propriedades de sedimentação durante a centri fugação, dificuldade na passagem pelo filtro bacteriolögico e sensibilidade para bactericidas, mas não a enzimas de àcidos nucleicos, rejeitando assim, a hipōtese de estar envolvido um virus, um viröide ou micoplasma, como agente causal do RS.

Organismos seme Thantes a xanthomonas vasculorum, foram isoladas de feixes vasculares de colmos de cana-de-açúcar infectados pelo RS (LIU et alii, 197.4). Mais tarde, esta teoria foi confirmada por TOKESHI et alii. (1974), porém, com for tes evidências de que um dos agentes causal da doença fosse Xanthomonas albilineans.

WEAVER et ali (1977) constataram que a bactéria é do tipo Gram positivo e, de acordo com KAO e DAMANN (1973) formam microcolónias filamentosas no xilema, as quais, se frag mentam facilmente nas exiraçöes a väcuo dando origem aos talos bacterianos:

Segundo CHEN et alii (1975) em vasos do xirema do capim elefante, em Taiwan, foi encontrada uma bactéria semelhante a bactēria do RS. Sendo esta bactēria tambēm isolada em cultura pura sobre o mesmo meio complexo usado para cultivar a bactéria do RS (DAVIS et alii, 1980; LIAO e CHEN, 1981). SuDo (1980) estudando cana-dé-açūcar com sinto mas característicos do RS, constatou a presença das bactérias Erwinia herbicola e Pseudomonas rubiisubalbicans, evidenciando a possibilidade do RS ser causado por um complexo de bacté rias.

NAYIAGER et alii (1980) estudando quatro diferentes bactérias isoladas de colmos de cana-de-açūcar infecta das com RS, em meio de Whites' modificado, verificaram que atravēs de microscópio eletrōnico e de contraste de fase havia algumas similaridades morfológicas entre estas bactérias 
e aquela associada ao RS. Porém, inoculando as quatro separadamente em cana-de-açūcar, uma delas produziu sintomas característicos na região nodal do colmo. Esta bactéria em meio de cultura apresentou todas as caracteristicas morfológicas, como organismo geralmente delgado, formando hastes pleomōrficas, produzindo septos e messossamas, como descrita por BAILEY (1976); DAMANN e DERRICK (1976); GILLASPIE e BLIZZARD (1976); CHEN et alii (1975) e RICAU et alii (1976).

DAVIS et alii. (1930) concluiram que a bactēria associada ao RS é o agente causal da doença, estabelecendo a identidade morfológica e serolōgica da bactéria associada ao RS e a bactéria cultivada em meio de culturá. Afirmações con firmadas por GILLASPIE et alij (1981) que após sucessivos iso lamentos da bactéria a partir de canas doentes. com RS, encon traram as seguintes características: cēlulas em forma de bastonetes retos ou 1 igeiramente curvos, medindo 0,25 a $0,35 \times 1,0$ a 4,0 nm; parecem se multiplicar por divisão das septos e pre sença de messossamas, colocando-as como membro do grupo das bactērias coriniformes fitopatogênicas, isto é: aeróbicas, imō veis, gram-positiva, não formam esporos, catalase positiva e oxidase negativa.

Todos os strains da bactéria agente causal do raquitismo do grama seda e da cana-de-açūcar, apresentam caracteristicas similares. Porém, straim da bactéria de canade-açucar difere do straim da bactéria do grama seda em que o straim do grama seda cresce rāpido em meio de cultura e produz um pigmento não difuso amarelo. As duas bactérias relatadas foram determinadas serologicamente, pelos testes de imuno fluórescência e dupla difusão. No teste de dupla difusão em ge 1 , o straim do grama seda contém um determinado antīgeno adicional que não estā presente no straim da cana-de-açūcar (DE VIS et alii, 1980; LIAO e CHEN, 1981; DAVIS et alii, 1983).

DAVIS et alii (1983) demonstraram experimenta? mente que a bactéria isolada do grama seda, mostrou ser patogênica, causando a doença denominada "Bermuda grass stunting." 
Porém, essa doença não ocorre na natureza. Neste mesmo trabaTho, observou que as bactērias causadoras do BS e do RS são patologicamente distintas, cada uma induzindo sintomas no seu hospedeiro natural, mas nunca no hospedeiro natural da outra bactéria. Entretanto, ambas as bactérias são capazes de se mu? tiplicarem nos vasos do xilema de ambos hospedeiros. No entan to, o agente causal do RS é experimentalmente transmissível para värias espécies de gramíneas, permanecendo em muitas par tes sem sintomas (STEINDL, 1961 e TOKESHI, 1980). Porém, não é conhecido o grupo de hospedeiros do straim do grama seda.

DAVIS et alii (1984) baseados nos estudos reali zados em strains da bactéria de vārias regiões do mundo, inclusive do Brasil, que causam o RS, em strains causadores do BS e em dados passados, propuseram a criação de um novo genéro, clavibacter, que acomodasse as bactērias corineforme fito patogénicas contendo o ācido 2,4 - diaminobutírico na camada pepitidoglycans da parede celular, incluindo as bactérias do BS e do RS. Sendo proposto pelos autores, o reconheciment das bactérias do BS e do RS como: Clavibacter xyli subsp. xyli sp. nov., subsp. nov., o tipo do straim da espécie e subespécie no qual está. o straim da cana-de-açūcar e clavibacter xyli subsp. cynodontis subsp. nov., o tipo de straim da subespécie na qual está o straim do grama seda.

Pela revisão da literatura verifica-se que a hi pótese de que o agente causal do RS seria uma bactéria corine forme foi confirmada e o seu cultivo em meio artificial não deixa mais dūvidas sobre a șua taxonomia e perfeita identifi c a ção.

\subsection{Disseminação}

O raquitismo da soqueira, por ser uma doença que não causa sintoma externo característico, é facilmente disseminado por tulete, a partir de colmos afetados e por instru mento de corte, por ocasião da colheita, plantio e tratos cul 
turais, de um lote para outro ou mesmo dentro do próprio lote (STEINDL e HUGHES, 1953; HUGHES e STEINDL, 1955; TODD, 1960; STEINDL, 1961; GALLI et a 1ii, 1968; MATSUOKA, 1975).

Segundo HUGHES e STEINDL (1955) a transmissão é bastante acentuada quando se faz o plantio mecánico. Porém, não existem dados experimentais publicados na disseminação do RS nos plantios manuais em que as canas são cortadas no interior do sulco.

FORBES et alii (1960) verificaram em trabalhos realizados na Louisiana, U.S.A., que cana-planta com 5,4\% de plantas infectadas (var. CP44-101), apös colheita mecânica se obteve $15,6 \%$ de plantas contaminadas na soca. E que mudas com $5,4 \%$ de infeç̧ão deram origem a canaviais com $21,2 \%$ de plantas doentes. Evidenciaram com isto, a importância deste tipo de disseminação nas sucessivas colheitas e multiplicações. Da dos estes, contestados mais tarde por MATSUOKA (1972), por se rem observações baseadas em sintomas internos na cana e partindo de material tratado termicamente. Afirmou este autor que a avaliação da percentagem de infecção pela diagnose direta na cana não é totalmente segura, pois foi constatado que em lotes obtidos de toletes tratados termicamente, a visualização de sintomas nas canas doentes restantes é muito difícíl. Deste modo, a percentagem inicial de infecção de $5,4 \%$, poderia ser maior e explicaria melhor as elevadas percentagens observadas posteriormente, devido a manifestação posterior de sintomas por plantas infectadas desde o início.

Experimentos de transmissã̃o do RS, envolvendo ve tores foram realizados, porém, não foram obtidos resultados conclusivos (MATSUOKA, 1975). No entanto, resultados preliminares de Charpentier e Schexnayder, citados por PEMBERTON e CHARPENTIER (1959), indicam o pulgão Rhopalosiphum maidis como possivel vetor. Porém, resultados conclusivos sobre a exis téncia de insetos vetores dessa doença não existem, devido a inexistência de sintomas externos bem definidos, dificultando em grande parte a realização destas pesquisas. 
Outros meios de disseminação são citados, porém sem provas concretas: ratos (WEHLBURG, 1956; ADSUAR, 1962); so 10 (ADSUAR e LOPEZ - ROSA, 1962); coelho (BOURNE, 1965); ratos; raposas e outros animais roedores (GALLI et alii, 1968). Segundo MATSUOKA (1975) a transmissão do raqui tismo da soqueira pelos instrumentos de corte se não for o único, é o meio mais eficiente de disseminação da moléstia.

Sendo o agente do RS uma bactéria sistémica não resta dūvida de que a transmissão mecánica e por mudas contaminadas são eficientes e por isso explicam a facilidade de dis persão do RS em todo o mundo.

\subsection{Diagnose da Doença}

2.3.1. Fatores que Interferem na Expressão dos Sintomas

Os sintomas externos mais constantes em plantas com RS são: crescimento irregular, plantas raquitticas, poucos perfilhos, baixa brotação de soqueira e colmos finos. Estes sintomas não são específicos da doença, sendo em consequéncia, de pouco valor na diagnose. (STEINDL, 1961; GILLASPIE et alii 1966 ; MATSUOKA, 1971 a).

Segundo HUGHES e STEINDL (1955), STEINDL (1961);

CARVALHO (1963) e GILLASPIE et alii (1966) sintomas internos em colmos maduros de cana-de-açücar como pontuações, vĩrgulas de cor rosados, amarelos ou avermelhados, aparecem nos feixes. vasculares da região nodal, também os nós imaturos situados logo" abaixo do meristema apical podem apresentar internamente uma coloração levemente rósea, logo após o corte. Porém, estes sintomas se confundem com o da escaldadura das folhas (T 0 KESHI et alii, 1974).

os sintomas de nós maduros são os mais preferidos, pois as descolorações em nós imaturos são considerados menos seguros, por serem menos constantes, nem sempre visiveis 
e, frequentemente, não ocorrem em colmos imaturos (HUGHES, $1956,1960)$.

Segundo HUGHES e STEINDL (1955) o sintoma do RS varia com a idade do colmo e condições climāticas. RICAUD (1974) confirma que a lém desses fatores, as caracteristicas varietais e o estado fisiológico da planta, também pode interferir na expressão dos sintomas. THOMPSON (1960) observou que os sin tomas do RS foram claramente visiveis, sob condições de estufa, quando não se forneceu āgua às plantas inoculadas com RS. Sendo estas observações confirmadas mais tarde por STEINDL (1961) e ROSSLER (1974), submetendo variedades de cana aos efeitos do RS à diferentes niveis de irrigação.

HUGHES e STEINDL (1955) citaram que descoloração de feixes vasculares não é uma reação específica do RS, podendo ocorrer em vārias doenças, como: Fusariose, Podridão Ver melha, Gomose, Escaldadura das Folhas e Estrias Clorōticas, sendo a descoloração vascular, normalmente, mais constantes nos nōs mais maduros da base do colmo estas observações foram confirmadas por TOKESHI et a 7 i (1974).

MATSUOKA (1971, 1972 a) reveliu que nos ensaios conduzidos com duas cultivares de capim elefante (Pennisetum purpureum schum) e um hỉbrido de capim elefante em condições favorāveis à maturação precoce, aumentaram a intensidade e a expressão de sintomas de descoloração vascular devido a infec ção do RS em capim elefante.

Segundo IRVINE (1975) a expressão sintomatológi ca em plantas novas infectadas por RS, foi acentuada após a aplicação de fertilizantes nitrogenados e mantidas à sombra e que essa expressão de sintomas típicos do RS, pode indicar con centração do agente da doença.

A revisão da literatura mostra que atravēs da sintomatologia do RS, não é possível avaliar o grau de sanidade das diferentes variedades de cana-de-açūcar. 
2.3.2. Reprodução de Sintomas ria Diagnose da Doença

Devido a não apresentação de sintomas externo típico para a diagnose do RS, vários trabalhos tem sido relatados procurando solucionar o problema. Os primeiros trabalhos com esta finalidade foram baseados nos sintomas de descolora ção vascular, relatados como características da doença (STEINUL, 1950) e confirmado por HUGHES e STEINDL (1955, 1956); ADSUAR e LOPEZ-ROSA (1962).

Diante dessa dificuldade, alguns autores procuraram desenvolver técnicas que permitissem um diagnóstico seguro da doença, pela utilização de plantas indicadoras: HUGHES e STEINDL (1956) testaram Nicotiana glutinosa, tomate e beringela; STEIB e FORBES (1957) mi lho e sorgo halepense; MATSUOKA (1972) Pennisetum purpureum Echinochloa colonum e Panicum maximum, en tre outras; STEINDL e TEAKLE (1974) "bana grass", hibrico de Pennisetun purpureum e $P$. americanum. Em testes de patogenicidade, TOKESHI et alij (1974) utilizaram capim elefante, milho doce e algumas variedades de cana-de-açūcar.

Sintomas do RS em hỉbridos de sorgo x capim su dão são bastante acurados e säo caracterizados pe 10 murchamen to e morte da planta (BENDA, 1971). Já BECHET (1976) sugeriu uma série de variedades de cana-de-açúcar e um clone de "bana grass" como indicadores, para rápidas diagnoses.

Segundo VALARINI (1978) apesar de todos esses esforços, na procura de uma planta que permitisse uma sintoma tologia caracteristica para diagnose segura da doença, a propria cana-de-açúcar ainda é a melhor planta indicadora, embo ra não apresente sintomas específicos.

SUDO (1980) menciona em seu trabalho que o teste com o capim elefante é inespecifico para a bactéria do RS, reagindo positivamente para diversas bactérias, fungos e leveduras.

Sequndo TOKESHI (1980) é possível infectar arti ficialmente em torno de 14 espécies de gramineas. Porém, todos esses testes biológicos são falhos por não serem especí- 
ficos para a bactéria do RS.

BETTI et alii. (1980) confirmam que testes com capimelefante, mesmo apresentando riscas de coloração vermelho alaranjada na região vascular dos nós basais, não é específico para o agente ou agentes causais do RS.

\subsubsection{Diagnose através de Testes Quĩmicos e Biológi- $\cos$}

ANTOINE (1957) procurou utilizar a técnica colo rimétrica, através do uso de 2, 3,5 - cloreto trifenil tetra zólico, que em contacto com tecido vivo produz um pigmento ver melho insolúvel, sendo esta alteração mais lenta em tecido sa dio do que em tecidos de cana doente. FARRAR (1957), observou que, quando seções longitudinais, retirados da periferia de nós maduros da parte basal de colmos da cana-de-açúcar, eram tratados com peróxido de hidrogénio a $3 \%$ combinado com ácido cloridrico hidratado, manifestavam uma coloração vermelho azu lada no tecido parenquimatoso vizinho aos feixes vasculares, enquanto em tecidos de cana doente nada ocorria. Porém, HUGHES (1958) utilizou as técnicas descritas acima, chegando a conclusão que nenhum dos testes oferece resultados seguros.

FIFE e STOKES (1959) com métodos de cromatogra fia, mostraram que a concentração de aminoácidos foi maior em extratos de folhas de cana-de-açücar com RS, do que em extratos de folhas de plantas sadias. Porém, os autores sugerem a necessidade de novos estudos para avaliar a eficiência do método.

ROTH e WHITEHEAD (1965) trataram a parte perifé rica do colmo, com uma solução de nitrato de prata e amônia e uma solução a $20 \%$ de hidróxido de potássio. A reação consistia numa coloração amarela nos tecidos sadios enquanto nos lo cais onde os feixes fibrovasculares estavam infectados surgiam estrias avermelhadas de fundo amarelo. Porém, devido a 
resultados contraditórios, os autores alegaram a necessidade de maiores estudos.

Os dados disponiveis na literatura mostram que a diagnose por testes quĩmicos e biológicos não tem precisão suficiente para detectar estado sanitário de mudas com baixos nỉveis de infeç̧ão.

\subsubsection{Testes Serológicos na Diagnose da Doença}

GILLASPIE et alii (1966) realizaram trabalhos de purificação do vírus tido como provāvel agente causal do RS e tentaram desenvolver um antissoro para este virus, visando uma possível identificação no laboratōrio e no campo. Em tentati va de purificação, antissoro foi produzido por GILLASPIE (1971) para dissolver preparaçoes infectivas de plantas doentes e al ternativamente, fraçöes de gama-globulina do antissoro produzido de plantas sadias foram separadas e usadas para absorção dos preparados. No entanto, nenhum método obteve sucesso, pois reduziram a infectividade.

Segundo DAMANN et alii (1977) a associação da técnica de serologia e microscopia eletrónica (SSEM) consti tuiu-se num método efetivo em mostrar uma bactēria caracterís tica associada com o RS e concluiram que esta técnica podia ser usada para diagnosticar esta doença com sensibilidade ma or do que a técnica de microscopia eletrónica com imersão rápida.

HARRIS e GILLASPIE (1978) utilizaram a técnica de imunofluorescência com antissoro específico para a diagno se da bactéria corineforme na diagnose do RS. Sendo um teste mais sensivel que a microscopia de contraste de fase, alegaram que podia ser usado rotineiramente com amostras de caldo bruto, mesmo contendo baixas concentraçoes da bactéria.

GILLASPIE (1978a) produziu antissoro obtido da bactēria associada com RS em plantas doentes da cana-de-açū 
car e um hỉbrido de capim sudão (Sorghum vulgare sudanensis). Observou que o antissoro causando um agregado da bactéria remove a infectividade do caldo obtido de cana-de-açūcar ou híbri do do capim sudão infectado pela bactéria. Nenhuma reação serológica foi detectada entre a bactéria associada ao RS e Corynebacterium flaccunfaciens, C. michiganense ou C. fascians, pelos testes de microaglutinação. GILLASPIE (1978b) afirma ainda, que a lém das observações citadas anteriormente não houve evidências de reação entre a bactéria do RS e Mycobacterium paratububu losis, M. tubuculosis, Erwinia amylovora, Agrobacterim tumefasciens, Xan thomonas pruni, Streptomyces scabies e. S. sp., pelo teste de microa glutinação.

Baseados no teste ELISA (The Enzyme Linked Imunosorbent Assay), em que a intensidade do desenvolvimento da coloração é diretamente relacionada com o número de bactérias presentes na amostra, GILLASPIE e HARRIS (1973) sugeriram um mé todo de seleção para resistēncia ao RS em grande escala. 0 teste ELISA detectou em torno de $4 \times 10^{6}$ células por mililitro ou em torno de trés bactérias por campo de microscōpio de contraste de fase. Entretanto, GILLASPIE e HARRIS (1979), re lataram possíveis limitações do mētodo, como baixa sensibili dade, alta absorção de fundo e resultados inconsistentes.

\subsubsection{Diagnose através de Microscopia}

Através de exames em microscōpio eletrónico e eletromicrografia, vārios autores tem observado bactérias nos xilemas de canas infectadas com RS (PLAVSIC - BANJAC e MARAMO ROCH, 1972; MARAMOROCH et alii, 1973; TEAKLE et alii, 1973, CHEN et alii; 1975; WORLEY e GILLASPIE, 1975; KAMIUNTEN e WAKIMOTO, 1976).

De acordo com GILLASPIE et alii. (1973) e STEINDL (1976) o RS pode ser diagnosticado através do exame de exuda dos do xilema, empregando-se microscopia de contraste de fase 
ou campo escuro, sendo estes mētodos mais acessíveis, menos dispendiosos, fáceis e rápidos, do que microscopia eletrónica que, a lém de requerer equipamentos caros, também requer pessoal treinado (STEINDL, 1976). Além disso a tecnologia envolvida limita severamente o nümero de amostras a serem examinadas (GILLASPIE, 1973).

Segundo BAILEY (1976) exames de bactérias pela microscopia de contraste de fase, em infusão de tecido contaminado parece ser um meio ütil de diagnosticar o RS principal mente em variedades que não apresentam sintomas nodais conspi cuos e também para confirmar diagnose baseado em sintomas nodais.

Para GILLASPIE et alii (1976) o nümero de bactē rias existentes no caldo bruto de colmos suscetiveis inocula dos com RS era maior que o nümero de bàctérias existentes em caldo bruto de colmos sadios.

RICAUD et alii (1976) revelaram que o organismo associado ao RS é facilmente distinguido das outras bactérias contaminantes, com o emprego de microscopia de campo escuro, devido as suas formas caracteristicas e sua morfologia comumente filiforme.

0 RS pode ser diagnosticado pelo exame de exuda dos do xilema, pelo uso de microscopia de. contraste de fase através da presença de bactéria constantemente associada a do ença, observada em toda parte da planta. Entretanto, devido ao baixo nümero de bactérias observadas em tecidos da parte apical do colmo e em tecidos de colmos jovens, torna-se necessário o uso de seções de colmos maduros, para uma maior segurança na diagnose (BAILEY, 1977).

RICHARDSON (1978) descreveu um método de extra ção de seiva do xilema do colmo de cana-de-açücar, usando a pressão positiva, na qual um grande nūmero de bactérias são obtidas sema necessidade de centrifugação, fazendo os exames diretamente em microscópio de contraste de fase.

KAO e DAMANN (1980a) observaram a presença da 
bactēria associada a o RS, em vasos do xilema, através, de exa mes em microscópio eletrónico de varredura.

A revisão da literatura mostrou que a diagnose pela visualização da bactéria do RS requer microscopia ötica ou eletrónica. Os custos são elevados necessitando de pessoal especializado o que o torna inviāvel para a maioria dos par ses produtores de cana-de-açúcar. Constata-se, portanto, falta de um método de avaliação de sanidade de mudas mais efici ente e de baixo custo, adequado para países sub-desenvolvidos.

\subsection{Controle}

0 emprego de variedades resistentes, toleranies ou imunes é prática citada por muitos autores (HUGHES e STEINDL, 1953; STEINDL, 1961, 1974; STEIB e CHILTON, 1968; WISMER E URA TA, 1967 e WISMER, 1971). Porém, estas variedades não e ram ob tidas em programas dirigidos de melhoramento.

Posteriormente, STEINDL (1974) relatou que o con trole do RS com variedades tolerantes, poderia ser desenvolvi. do desde que se estivesse preparado para conviver com a doen ça e depender inteiramente desta variedade.

Segundo MATSUOKA (1975) é bem possivel que estu dando a ārvore genealógica da variedade H60-6909, seja encon trado o espécimem do qual foi herdado o caräcter de imunidade, sendo provavelmente de valor adicional para posteriores traba lhos de melhoramento visando o controle do RS.

TEAKLE et alii (1975) baseados nas informações de STEINDL (1961) e WISMER (1971) testaram a resistência de va riedades à passagem de água em seçõos de colmos e suspeitaram que a anatomia vascular possivelmente estaria envolvida na resistência a o RS. Diante dos resultados, levantaram a hipótese do movimento de água ser paralelo a resistência ao mo vimento da bactéria, podendo isto limitar a colonização na planta. Comprovando a hipótese, os autores observaram existir 
correlação entre a vazão de āgua em seç̧ão de colmos sadios e a resistēncia ao RS: variedades imunes apresentaram alta resistência ao movimento de àgua; variedades resistentes foram moderadamente resistentes a vazão de àgua; finalmente, varie dades susceptiveis apresentaram uma baixa resistência ao movi mento de àgua. Utilizando da mesma metodologia, estudaram a propriedade da tinta nanquim passar através das secções dos colmos, colorindo os vasos funcionais, tendo observado que va riedades imunes, com alta resistência a movimento de àgua, apresentavam poucos feixes vasculares escurecidos, em compara ção às variedades suscetîveis de alto fiuxo.

VALARINI (1978) modificando a metodologia de

TEAKLE et alii (1975) concluiu existir uma relação entre a di ferença da vazão de āgua em colmos de cana-de-açūcar sadios e doentes e o grau de suscetibilidade. Sugeriu com isto, a pos sibilidade de se avaliar a suscetibilidade de variedades ao RS, pela determinação da vazão de àgua. Segundo este autor, es ta técnica seria um método räpido, econōmico e eficiente na se leção de plantas resistentes ao RS. Esta sugestão,foi confirmada por DOUGLAS (1981) e CRUZ (1983).

Segundo VALARINI e TOKESHI (1930) os fatores pres são de vãcuo, posição do nó no colmo e perīodo de armazenamen to, interferem na avaliação da resistência a o RS, pelo método de vazão de àgua.

TEAKLE et alij (1978) observaram através de es tudos em microscópio que variedades resistentes com baixa ta $x a$ de fluxo de àgua, apresentavam maior nümero de ramificações nos vasos do metaxilema em comparação con nōs de varieda des suscetíveis. Segundo STEINDL (1961), substāncias como ti lose e gomas são comumente produzidas pela planta em reação ao agente do RS, cujo mecanismo de defesa são possíveis de ex plicar o bloqueio mais rápido dos pequenos poros das varieda des resistentes do que os grandes poros das variedades susce tiveis.

Um método de seleção de variedades tolerantes a.o 
RS através de microparcelas, comparando o peso de colmos tratados termicamente e inoculados (RS), foi sugerido por MATSUO KA (1980).

DOUGLAS (1981) concluiu que a anatomia vascular não é suficiente, por si sō, para explicar o grau de susceti bilidade entre as variedades e que a contagem de bactérias no xi lema de variedades suscetíveis e tolerantes, não é um bom critério de avaliação. Apontando como tolerantes as variedades CB45-3, CB47-355, CB49-62, C0775, H69-3775, H60-6909 e IAC52150 e suscetiveis ao RS, as variedades CB41-76, CB45-155, CB 53-98, IAC 50-134 e NA56-79. As reações dessas variedades foram confirmadas por CRUZ (1983).

Segundo CRuz (1933) o método de vazão de água

em colmos de cana-de-açūcar mostrou ser mais preciso que o mé todo de produção de colmos ( $\mathrm{kg} / \mathrm{parcela}$ ) em microparcelas, nas avaliações de niveis de resistência ao RS. Afirma ainda, que através da coloração do xillema é possível visualizar falhas do tratamento térmico no controle do RS.

os autores que procuraram avaliar o nivel de re sistência de variedades a o RS levam a um ponto comum, ou seja, que a anatomia e fisiologia vascular estão diretamente relacionada com o nivel de resistência ao RS. Medindo-se a eficiên cia do sistema vascular em transportar àgua em plantas sadias e doentes, tem-se um retrato do nível de resistência das plan tas a esta doença:.

\subsubsection{Plantio de Material Sadio}

0 plantio de material sadio e prevenção da disseminação do agente causal são as principais medidas de controle do raquitismo da soqueira (STEINDL e HUGHES, 1953).

Segundo HUGHES e STEINDL (1955), devido a ausên cia de sintomas externos de fácil identificação, a obtenção de material sadio pela prātica do "roguing" não é aplicável. 
Portanto, o material sadio deve ser obtido de outras maneiras. Diversos métodos têm sido testados e empregados no mundo todo. os principais métodos de tratamento de mudas são. a) àgua quen te a 500 C por 2 horas (HUGHES e STEINOL, 1955); b) vapor quen te a 530 C por 4 horas (STEIB et alii, 1956) e; c) ar quente a $530 \mathrm{C}$ por 8 horas (HUGHES e STEINDL, 1955 ).

a) Tratamento com ăgua quente (500 C/2 horas)

HUGHES e STEINDL (1955) foram os pioneiros nos estudos sobre o tratamento curativo de toletes ou colmos inteiros de cana-de-açūcar infectados com RS. Desde então, tal prática tem sido adotada mundialmente, sendo o tratamento de toletes de 3 a 5 gemas a forma mais frequente. No entanto, ca na inteira também podem ser tratadas, pois, o comprimento do colmo não tem influéncia no tratamento, sendo o diàmetro do colmo o fator de maior influência (ANTOLNE, 1957 e GALLI et alii, 1968).

Segundo HUGHES e STEINDL (1955) e SCHEXNAYDER (1956) o controle adequado da temperatura é importante pois o binōmio temperatura/tempo recomendado está no limite de to lerāncia das mudas de cana, acima do qual a germinação seráa excessivamente baixa ou até nula. Também está no limite mínimo exigido para a inativação do agente causal do RS (HUGHES e STEINDL, 1955; FARRAR, 1957; HUGHES, 1958).

Porém, STEINDL (1961) a o constatar escape de bactérias em mudas tratadas a 500 c por 2 horas, relatou a ne cessidade de se estender o tempo de tratamento para 3 horas. Entretanto, MATSUOKA (1983, 1984) comparando a produção entre progênies de canas tratadas por duas e três horas a $500 \mathrm{C}$, re a lmente não verificou diferenças de produção, embora, tenha havido aumento de produção de $22 \%$ em ambos os tratamentos em relação a cana doente, com média de trés cortes e de três variedades. Constatou, sim, maiores danos à germinação com o 
tratamento no tempo de três horas.

Procurando explicar tal fato, FARRAR (1957) ob servou que era possível curar canas com RS com tratamento a $490 \mathrm{C}$ por duas horas ou 589C por uma hora. No entanto, RICAUD (1968) citado por MATSUOKA (1975), determinou que para uma tem peratura de $500 \mathrm{C}$ atingir o centro de um tolete de trés gemas com 3,9 cm de diâmetro é necessārio um tempo de 28 minutos, e de 65 minutos em toletes de $4,5 \mathrm{~cm}$ de diàmetro. Portanto, nas condições usuais de toletes de 2,5 a $3,5 \mathrm{~cm}$ de diāmetro, 0 tratamento por 2 horas seria o suficiente para se ter a tempe ratura de 500 C no centro do tolete pelo minimo de uma hora re querida. TOKESHI (1980) concluiu que, o comprimento do tolete e diāmetro do colmo, nas condições usuais não interferem na eficiência do tratamento. Existe, portanto, um limite biológi co impossivel de ser suplantado fisicamente. Acima de 510 c ocorre a morte das gemas da cana e, no limite de tolerāncia, a cura não é total (MATSUOKA, 1983,. 1984).

MATSUOKA (1976) demonstrou o grande efeito bené fico que se obtēm quando se realiza o tratamento térmico em canas naturalmente infectadas. Trabalhando com toletes de 4 a 5 gemas, em tanque convencional de 10.000 litros de água, observou que o aumento médio de produção em cana-planta e cana-soca, numa variedade suscetível, a CB49-260, foi de $25 \mathrm{t} / \mathrm{ha}$. MATSUOKA e AGUILLERA (1901) observaram em experimento com cinco variedades, em média de planta e soca, que - raquitismo da soqueira causou perdas de mais de $20 \%$.

CHU et alii (1959); STEINDL (1961); MATSUOKA (1930); TOKESHI (1980) recomendam que, para se ter em anos su cessivos mudas com sanidade cada vez maior, é necessārio que a técnica de formação de viveiros de cana tratada termicamen te $(50,5$ oc $/ 2$ horas) seja um processo continuo. observações validadas por MATSUOKA $(1983,1984)$ quando encontrou após cin co multiplicações de material oriundo de tratamento térmico, níveis danosos de infecção com RS.

No Brasil o material sadio é obtido através de 
tratamento térmico em água aquecida a $50,58 \mathrm{C}$ por 2 horas. Es tas condiçoes são criticas para o sucesso do tratamento, uma vez que temperaturas mais baixas ou menos tempo de exposição não inativam a bactéria e temperaturas mais altas e maior tem po de exposição provocam alta taxa de mortalidade das gemas (TOKESHI, 1980; MATSUOKA, 1983; MASUDA, 1934).

Segundo MATSUOKA $(1933,1934)$ para a formação de viveiros de mudas de cana-de-açūcar é necessārio o tratamento em água aquecida a 50,50C por 2 horas. Apesar dessa prática realmente proporcionar mudas de boa sanidade, a cura não é com pleta e que o retorno da doença a níveis danoso poderia estar ocorrendo em tempo relativamente curto. Portanto, o exato conhecimento desse fato torna-se necessário para um correto programa de obtenção de mudas sadias. Concluindo ainda em seu trabalho que: 1) o tratamento térmico em cana doente propicio na recuperação altamente significativa da capacidade produtiva das variedades de cana-de-açūcar; 2) não há compensação no prolongamento do tratamento têrmico de duas para três horas; 3) a cura pelo tratamento em àgua aquecida não é total e abso luta, mesmo tratando mini-toletes; 4) reinfecção que ocorre a partir das plantas com infecça residual, é tal que, após 5 multiplicações, o material já se apresenta com nível de infec ção comparāvel a um material não tratado.

DAMANN e BENDA (1983) trabalhando em casa de ve getação, observaram que a germinação foi melhor quando mudas de cana-de-açúcar era tratada termicamente para controlar o RS, do que não tratada. Concluiram que o tratamento térmico' comercial decrescé a incidência do RS, porém não elimina completamente.

Segundo CRUz (1983) a travēs da coloração do sị tema vascular de mudas curadas pela termoterapia foi possivel detectar em cana planta a ocorréncia de plantas contaminadas apesar da ausencia total de outros sintomas externos e inter nos.

Segundo MASUDA (1984) canaviais formados com mu 
das não tratadas podem apresentar prejuízos da ordem de 20 a $30 \%$, sem que o produtor perceba. A taxa de mortalidade de gemas varia de variedade para variedade, podendo ser de $40 \%$ no caso da NA56-79 ou chegar a $80 \%$ ou mais como CB-47-355. Mencio na também, que a idade da muda influi bastante na taxa de mor talidade das gemas. Mudas a ós 12 meses são as ideais para 0 tratamento. Mudas mais novas apresentam alta taxa de mortali dade devido ao calor, enquanto que as mudas mais velhas, embo ra resistam mais a calor, fisiologicamente são menos aptas a germinar.

Segundo MATSUOKA (1984) tratando termicamente ca na inteira das variedades CB41-76; CB49-260 e IAC 52-326, obteve ganhos médios de 13,24 e $27 \%$ em cana-planta, cana-soca e ressoca, respectivamente. Portanto, relata MATSUOKA (1983), que o tratamento térmico independentemente de ser toletes ou canas inteiras propicia mudas com elevada capacidade produti va, embora se saiba que a cura nunca é total, qualquer que se ja o tamanho do tolete.

HEAGLER e CHAPMAN (1984) estudando o retorno eco nōmico com o investimento do tratamento térmico $(50,50 \mathrm{c} / 2$ ho ras) no controle do RS da cana-de-açúcar na Louisiana, encon traram através da análise estatística uma resposta altamente significativa na produção, associada com o tratamento térmico no controle do RS. Numa análise económica indicou que o trata mento térmico foi um bom investimento, comótimos e constantes retornos em dólares, aproximadamente, um. retorno de 11,5 dólares por dólar investido.

b) Tratamento com vapor quente (5300/4 horas)

SRIVASRAVA et alii (1977) desenvolveram a unida de de tratamento a vapor, e observaram que não houve efeito negativo à germinação, quando mudas foram tratadas a 530 c por 4 horas. Resultados similares foram encontrados por STEIB e 
CIFUENTES (1976) tratando mudas em um tempo mäximo de 3 a 5 horas.

SHUKLA et a?ii (1979); ONGAMA (1978) e DHILLON

et alii (1983) relataram que o tratamento a vapor a $540 \mathrm{C}$ por 4 horas foi eficiente no controle do RS, proporcionando aumen to de germinação e por conseguinte, uma maior produtividade em relação a cana-de-açūcar não tratada.

SAXEN et alii (1981) revelaram que o agente do RS reduz o processo de crescimento metabólico normal das raí zes de cana infectada. Porém o tratamento a vapor quente (530 C/ 4 horas) de colmos infectados com RS teve um efeito benéfico sobre o completo desenvolvimento radicular, quando comparado com plantas doentes. Este efeito foi maior com a aplicação de enxofre após a eliminação do agente causal do RS pelo tratamento térmico.

c) Tratamento com ar quente (5800/3 horas)

HUGHES e STEINDL (1955) estudando o controle do RS na variedade Q28, em forno fechado, com ar na temperatura de 530 C e 540 C por 3 horas, ou a 500 C por 24 horas, verifica ram que a variedade ficava livre da doença. Observaram ainda, que a germinação era bastante satisfatōria, mesmo sendo utili zados toletes imaturos. Resultados semelhantes foram relatados por STEIB e CHILTON (1956) e STEIB et alii (1956) quando usaram cana jovem (imatura) em um tratamento com ar quente a 580 C por 8 horas sendo a germinação muito pouco afetada.

Pelos dados da literatura não hã dūvida de que até o momento a termoterapia de mudas é o único processo comer cial de cura de material infectado e que esta cura é incomple ta. A infecção residual nas mudas curadas é difícil de ser de tectada devido a inexistência de metodologia simples, eficien te, eficaz e aplicável em larga escala. 
2.5. Movimento de Agua na Planta em Função da Anatomia Va cular, na Resistēncia do RS

0 movimento de àgua nas plantas é um processo complexo, que leva a seiva bruta das raízes até as folhas, sen do chamado fluxo transpiratório (SUTCLIFFE, 1980). 0 movimen to ocorre em resposta ao gradiente de potencial de água entre as superfícies transpirantes e a solução do solo, causado prin cipalmente pela transpiração, sendo aumentada pela pressão ra dicular resultante do acúmulo de solutos no xilema das raízes (VAADIA et alii, 1961; SUTCLIFFE, 1980).

LOUSTALOT (1945) demonstrou que folhas de pecan desempenharam respiração e fotossintese subnormal, quando a umidade do solo estava entre muito baixo ou muito alto. Mostrou também, um relacionamento entre o grau de declíneo de fo tossintese e a severidade dos estresse de umidades. Além dis so, constatou um retardamento no restabelecimento que diferiu entre a taxa de fotossintese de manhã e à tarde.

LUDWING (1952); WAGONER E DIMOND (1954); DIMOND (1955) citaram que a diferença na taxa de vazão entre plantas de tomate sadias e infectadas por Fusarium não tem sido expli cada pela quantidade de micélio, mas sim pela presença nos va sos de substāncias transparentes semelhantes a goma. SAALTINE e DIMOND (1964) usando solução corante nos experimentos demons traram que a redução na vazão de água estava correlacionada com o nümero de vasos em que o transporte é bloqueado.

SCHEFFER e WALKER (1953) avaliaram o bloqueio dos vasos em seç̧ões de caules e tomate sadios e atacados por Fusarium, pelo movimento de um corante, em condições que favo reciam a transpiração. Os a utores observaram que muitos dos va sos ficavam descoloridos e que os peciolos de folhas murchas permaneciam livres do corante: Quando as folhas estavam murchas apenas de um lado, só o lado tūrgido ficava colorido. Con cluiram com isto que o sintoma de murcha era devido à não con dução de aḡua. 
HUGHES e STEINDL (1955) observaram que, em comparação com plantas sadias, o RS causa sérios déficit de água durante as horas mais quentes do dia, em solos com baixa umidade. STEINDL (1961) fazendo exames histológicos em secções de feixes vasculares descoloridos de cana-de-açūcar afetadas' pelo RS, observou que muitos dos vasos estavam obstruídos com substāncias gomosas.

ASHTON (1956) estudou o efeito da alternāncia do nĩvel de água no solo na fotossîntese da cana-de-açūcar. Os resultados mostraram que o indice fotossintético declinou com o declínio da umidade do solo, do ponto máximo da capacidade de campo do solo para o ponto de murchamento permanente. Entretanto, a taxa de declínio não foi uniforme e o nível original de fotossintese foi conservado, até que a falta de água no solo se aproximou do ponto de murchamento.

THOMPSON (1968) observou que o RS, quando com binado com fatores adversos, como seca prolongada, produz efe $\underline{i}$ to desastrosos sobre a cana-de-açūcar. Porém, esses efeitos são frequentemente mascarados, quando as condições de cresci mento são boas, com irrigação a dequada. Essas observações fo ram confirmadas mais tarde por ROSSLER (1974) ao descrever os efeitos do RS no rendimento da cana-de-açūcar submetida a três regimes diferentes de irrigação.

VALARINI (1978) observou notōrias diferenças de vazão de água em seçcões de colmos sadios e inoculados com caldo bruto (RS), , em duas variedades altamente suscetíveis, e que essa obstrução à passagem de ägua nos vasos condutores foi devida a alterações nos feixes vasculares, da região nodal do colmo, pela presença física do patógeno ou reação da planta através da emissão de tiloses ou liberação de substâncias go mosas.

VALARINI (1978) e DOUGLAS (1981) observaram que a vazão aumentou apōs ter chovido, independentemente do trata mento e da época de determinação da vazão. A tensão provocada pela falta prolongada de àgua no solo e na planta, causava fe 
chamento dos estōmatos, não ocorrendo a fotossíntese e, em con sequência, diminuia o fluxo de água na planta. A respiração tambēm seria diminuida devido a deficiēncia de oxigēnio (SUT CLIFFE, 1980).

TEAKLE et alii (1975) comentaram a possibilidade de a anatomia vascular estar envolvida na resistência ao RS, baseados na hipótese de que a resistēncia ao movimento de água seria paralela a resistencia ao movimento do agente do raquitismo. Concluiram que a anatomia vascular, possivelmente na forma de um pequeno numero de vasos continuos, que pas sam através dos nós, possa ser um fator de resistência, imuni dade e tolerância de clones ao RS.

VALARINI (1978) determinou que, com exceção do diāmetro do colmo, os fatores armazenamento, pressão de vācuo, sentido do colmo, localização do nō no colmo, idade do colmo, distribuição da doença dentro da touceira, colmos injuriados por brocas (Diatraea sppl e outras doenças vasculares interfe rem na avaliação da vazão do colmo. Nas variedades tolerantes a queda de vazão de água entre colmos sadios e inoculados foi pequena em relação às variedades suscetíveis. A variedace NA5679, que não apresenta sintomas internos apreciáveis, mostrouse bastante suscetível ao RS, por esse método, levando o autor a concluir que existe correlação entre a diferença de va zão de água em colmos sadios e doentes de cana-de-açúcar e o grau de suscetibilidade ao RS; a vazão de água em colmos é di retamente proporcional ao número de vasos funcionais e, por esse método, é possível avaliar o grau de suscetibilidade das variedades.

KAO e DAMANN (1980) revelaram que a velocidade de transpiração de brotos cortados de cana, são significativa mente inferiores nas canas com RS e a pressão nas raízes da cana doente é tambēm significativamente menor que nas canas sadias. Por conseguinte, a enfermidade afeta a habilidade da planta para absorver e transpirar água.

os resultados dos autores citados na revisão mos 
tram que o movimento de āgua na planta é alterado em plantas com doenças vasculares e que a medida da vazão de àgua ou nū meros de vasos funcionais permite avaliar melhor os efeitos do RS na intensidade de doença.

2.6. Medidas da Intensidade da Doença pela observação Vi sua 1

O primeiro e mais notāvel exemplo histórico de um diagrama de escala para medir intensidade de doença de plan tas, foi o de Nathan Cobb publicado em 1892, denominado esca la de Cobb, para ferrugem de folhas de trigo. Ele apresentou' folhas de trigo infectadas, mostrando diagramaticamente cinco graus de variação de ferrugem, com 1, 5, 10, 20 e 50 por cento, respectivamente, de ārea ocupada pela pústula (CHESTER, 1959; LARGE, 1966; HORSFALL e COWLING, 1978).

LARGE (1966) ci.ta que Melchers e Parker

(1922) publicaram uma modificação da escala de Cobb a qual tem sido usada desde 1917 nos Estados Unidos para estimativa de ferru gem em caule de trigo. Escalas representando $5,10,25,40,65$ e 100 por cento de ferrugem no caule, foram então preparadas simplesmente copiando a escala de Cobb para ferrugem de folha, com a adição ou emissão de pequenas pústulas. As duas escalas foram reproduzidas e discutidas por Peterson et alii. (1948), que desde então mostraram vārias séries de escalas apresentan do $1,5,10,20,30,40,50,60,70,80,90$ e 100 por cento cobertas com pústulas de ferrugem de vārios tamanhos.

MCKNNEY (1923) demonstrou ser possivel estimar as doenças quantitativamente, pelo aspecto visual. Para isso, "seedlings" de trigo infectados por podridão de raízes, foram separadas em cinco classes de acordo com o grau de infecção, e a cada "seed?ing" foi dado um indice numérico. As classes foram descritas como: $0,00=$ sem doença; $0,75=$ muito leve; $1,00=1$ eve; $2,00=$ moderada e, $3,00=$ infecção abundante, sen 
do então conhecido como "īndice de McKNileY", também chamada "Classificação numérica".

Algumas outras escalas de interesse ou de valor histōrico como exemplo, foram as de Theon e Stout (1930) para sarna de maçã e de Veestrup et alii (1945) para requeima de fo Iha de milho, ambas reproduzidas por Chester (1950) e croseall et alii (1952) para sarna de frutos e folhas de maçã; Large e Honey (1955) para sarna comum da batata; Clarke e Corke (1956) para infecção e defoliação da groselha preta, pela mancha das folhas, citados por LARGE (1966).

Segundo LARGE (1966) a variação entre 1 e 100 por cento ilustrados nas escalas de doença, deveria não ser muito ampla, devendo ser claramente distinguível pelo olho hu mano. Cita ainda, que Hosfall (1945) havia demonstrado que ela não era adequada, fazendo duas importantes considerações em seu sistema de classificação: a) que de acordo com a regra de Weber-Fechver, a variação visual progride em passos logarítmi cos e, b) que a classe de variação é muito ampla. Concordando com HORSFALL e BARRATT (1945) que perceberam que a acuidade do olho humano realmente ver tecido doente abaixo de $50 \%$ e te cido sadio acima de $50 \%$. Sendo, $50 \%$ o ponto médio da escala que deverá ser ilustrado. Deste modo, as classes de variação são: 0-3; 3-6; 6-12;12-25;25-50; 50-75; 75-87; 87-94:e 97-100\%. Assim sendo, a escala considera os tecidos doentes na unidade logaritmica abaixo de 50\%, e tecidos sadios, na mesma unidade, acima de 50\% (CHESTER, 1959; LARGE, 1966; HORSFALL e COWLING, 1978 ).

CHESTER (1959) comenta que um bom meio para medir doença de planta, onde plantas ou örgãos diferem no grau de ataque, é registrar o nūmero de plantas ou órgãos em cada classe de percentagem de doenças como: $0-10 \%$; $10.1-20 \% ; 20.1-$ $30 \%$; $30.1-40 \% ; 40.1-50 \%$; $50.1-60 \% ; 60.1-70 \% ; 70.1-80 \% ; 80.1-90 \%$ e $90.1-100 \%$ e reduz estas classes para uma simples expressão numērica de intensidade de doença, como: $1.0 ; 2.0 ; 3.0 ; 4.0$; $5.0 ; 6.0 ; 7.0 ; 8.0 ; 9.0$ e 10.0 , respectivamente. 
Ainda, segundo CHESTER (1959) a escala descriti va pode ser ütil se as classes são realísticas, bem distintas, usāveis na prātica, comparāveis com outros operadores, em um ou mais locais ou estações.

Marh et alii. (1937), citado por HORSFALL e COWLING (1978) usaram classes de requeima e defoliação de batata, como segue: 0 = sem requeima; 2 = lesões escaças; 4 = 1esões de re queima frequentes; 8 = lesões de requeimas abundantes, algumas defoliações e, $10=$ defoliação completa.

observa-se pelos dados da literatura que a ava liação do nỉvel de doença empregando escalas padrões é prātị ca comum para muitas doenças. A falta de uma escala.padrão pá ra avaliar o nivel de obstrução vascular causado pelo RS foi uma das dificuldades superada pela presente pesquisa. 


\section{MATERIAL E METODO}

\subsection{Variedades}

Na padronização de sintomas do RS, na determina ção de fatores que interferem na coloração do xilema pelo mé todo do fluxo transpiratório e na comparação dentro de cada método, foram utilizados colmos das variedades CB41-76 e NA5679 originados de viveiros tratados termicamente (TT) à 50,50 C por 2 horas e de viveiros inoculados com caldo bruto de col mos doentes (RS), sendo o experimento instalado em área do De partamento de Fitopatologia da Escola Superior de Agricultura Luiz de Queiróz - SP.

Para o teste de aplicação do método de coloração do xilema pelo fluxo transpiratörio, no controle de quali dade de viveiros e canaviais comerciais de cana-de-açúcar usou-se canas das variedades IAC51-205 e da NA56-79, retiradas de viveiros tratados termicamente, pertencentes à Estação Experimental de Piracicaba, em Piracicaba, SP; Estação Central do IAA/PLANALSUCAR em Araras, SP e Usina da Barra S/A., Barra Bonita, SP. 


\subsection{Obtenção do Inóculo e Inoculação}

0 inōculo utilizado foi obtido a partir de caldo bruto das variedades CB41-76 e CB49-260, inoculados com RS e acrescido de àgua na proporção $2: 1$, respectivamente. 0 méto do de inoculação foi o de imersão dos minitoletes na suspeñsão de inóculos por 15 minutos.

\subsection{Soluções Corantes e Diluições}

Diferentes soluções corantes foram testadas no desenvolvimento do presente trabalho: Safranina 0 e Anilina Vermelho 145 na concentração 2,5\% em etanol 95\%; Vermelho Bor deaux-S $(C-2)$ e tinta nanquim na concentração $2,5 \%$ em ägua destilada; Corante Azul HEINE e Tingecor Vermelho 9 na concen tração 2,5\% em àgua aquecida (TUITE, 1969). Todas elas foram diluî́das na proporção 1:10, em àgua destilada.

\subsection{Métodos}

Na realização do trabalho foram utilizados três métodos: 1) Vazão de āgua (VALARINI, 1978); 2) Vazão de solução corante (VALARINI, 1978 e CRUZ, 1983) e, 3) Coloração do xilema de colmos de cana-de-açúcar pelo fluxo transpiratório.

3.4.1. Método de Vazão de Āgua em Colmos de Cana-deAçūcár

A metodologia empregada foi a descrita por TEAKLE et alii (1975), modificado por VALARINI (1973). O aparelho de nominado fluxōmetro, utilizado para medir a vazão de āgua atra vés do colmo de cana-de-açūcar, foi o mesmo usado por VALARINI 
(1978), VALARIN I e TOKESHI (1920), DOUGLAS (1931) e CRUZ (1983). A vazão de água foi avaliada em seç̧ões de colmos tratados termicamente (TT) e inoculados com caldo bruto (RS) medindo $8 \mathrm{~cm}$ de comprimento, compreendendo o 49 ou 50 nó basal, sob uma pressão de vācuo constante de $30 \mathrm{~mm}$ de $\mathrm{Hg}$ por 15 minutos.

A extremidade superior da seçãa do colmo foi inserida em uma luva de borracha e encaixada no frasco de văcuo através de um funil metálico. A outra extremidade foi adap tada em uma outra luva de borracha que permanecia constante mente cheia de água destilada, ficando assim a seçãa do colmo invertido em relação ao colmo na planta, permitindo a pas sagem de àgua no mesmo sentido da seiva bruta.

\subsubsection{Método de Vazão de Solução Corante}

A metodologia empregada neste caso foi a mesma do ítem 3.4.1., apenas substituindo a água destilada por solu ção aquosa de Safranina 0, citada no it tem 3.3 .

3.4.2.1. Padronizaçăo da Escala de Sintomas do RS, pela Coloração do Xilema

Após a coloração do xilema as seç̧ões de colmos foram cortadas transversalmente no anel de cera, próximo a re gião do nó, para observação visual da variação de disfunção dos vasos, representados pelos espaços não coloridos do nó, sendo então, desenhados em plásticos transparente. A essas va riações foram atribuídas notas em uma escala de sintomas variando de 1 a 6 conforme indice de Micknney, MICKNNEY (1923), onde 1 e 6 equivalem a $16,33 \%$ e $100 \%$ de vasos coloridos, res pectivamente. Elaborada a escala de sintomas esta foi fotogra fada, usando-se uma câmara fotográfica NIKKON AS, com lente 
Micro-NIKKON 33 min $7: 35$, com filme diapositivo Fuji chrome 100 ASA e Fujicolor. 100 ASA.

A determinação do indice de contaminação (IC) do RS é dado pelas fórmulas:

Percentagens de vasos coloridos $(V C)=\frac{\sum \text { das notas } \times 100}{\text { no de colmos testados } \times 6} \%$ e, $I C=100-V C \%$

Para o corte das secções do colmo foi usado o instrumento denominado "guilhotina", que consiste de um facão fixado a duas láminas de ferro galvanizado (Apēndice 1), sendo que, na região pontilhada, uma lâmina será dobrada para a es querda e a outra dobrada para a direita e estas presas a um suporte de madeira de $35 \times 200 \times 800 \mathrm{~mm}$ de espessura, largura e comprimento, respectivamente, conforme Apēndice 2.

Para facilitar os 10.000 desenhos de nós colori dos, o plástico transparente foi bobinado em canudos de $50 \mathrm{~mm}$ de diâmetro por $650 \mathrm{~mm}$ de comprimento, denominados "papiros". Estes "papiros" foram encaixados nas extremidades de um quadro de madeira, em forma de retāngulo, com $500 \times 400 \mathrm{~mm}$ de com primento e largura, respectivamente, ficando desse modo, 0 plástico completamente esticado, conforme Apēndice 3.

3.4.2.2. Tempo Mínimo Necessārio para Coloração do Xilema, pelo Método de Vazão de So lução Corante

Após a padronização dos sintomas do RS, no tempo de 15 minutos à pressão de vácuo constante de $30 \mathrm{~mm}$ de $\mathrm{Hg}$, parcelou-se o tempo em intervalos de 2, 4, 6 e 8 minutos, afim de se determinar o temp̣o minimo na coloração do xilema sem que esta diminuição no tempo de coloração interferisse na eficiēn cia do método. 
Para cada tempo de coloração foram utilizados 2 seç̧ões de colmos de $8 \mathrm{~cm}$ de comprimento, compreendendo um ūnico nó e partes de internōdios adjacentes da variedade NA5679, tanto tratadas termicamente (TT) como inoculadas com cal do bruto (RS), distribuídas ao acaso para os oito bicos do flu xômetro. Cada tratamento foi repetido dez vezes, em um delineamento estatistico fatorial e, os resultados foram submeti dos à análise de variância e teste de Tukey, para comparação' de médias, conforme esquema estatístico representado no Quadro 1 .

3.4.3. Método de Colora ção do Xilema pelo Fluxo Trans piratório

Neste método, a solução corante foi succionada pelo fluxo transpiratório natural do colmo, substituindo a bom ba à vácuo. Para isto, colmos inteiros de viveiros formados com cana tratadas termicamente (TT) e colmos de viveiros inoculados com caldo bruto (RS), após novamente cortados no internódio entre os nós 3 e 4 foram introduzidos imediatamente em recipi entes (baldes plásticos, capacidade 10 litros), contendo 1,5 litros da solução corante, permanecendo em imersão por 60 mi nutos, sendo amparados por um suporte de madeira com $1200 \times$ $400 \times 400 \mathrm{~mm}$ de altura, comprimento e largura, respectivamen te, conforme Apêndice 4.

Após os 60 minutos, os colmos foram retirados da solução corante, cortados transversalmente no anel de cera, prōximo à região do primeiro nó basal colorido e classificados de acordo com a escala de sintomas, descrita em 3.4.2.1.

3.5. Fatores que Interferem no Método de Coloração do Xile ma pelo Fluxo Transpiratório

A metodologia descrita no item 3.4.3., foi a mes 
ma empregada na determinação dos fatores a seguir: 'altura de recorte do colmo, hora de corte da muda, tempo de cavitação, corantes, tempo de coloração, interferéncia de broças e umida de do solo.

Os resultados obtidos foram avaliados através da escala de sintomas descrita no item 3.4.2.1. para cada fator estudado. Os resultados foram submetidos à anālise de variāncia e teste de Tukey para comparação de médias, nos delineamentos estatisticos fatorial e inteiramente casualizado, conforme Quadros 1 e 2 , respectivamente. As notas foram transfor madas em percentagens de vasos coloridos e representadas gra ficamente, na forma de Figuras.

\subsubsection{Altura de Recorte do Colmo}

Antes dos colmos serem merguihados no corante, foram novamente cortados para eliminar a cavitação dos vasos. Este corte foi determinado na variedade CB41-76, em dez repetições de colmos cortados no internōdio 1 e 2 e dez repetições cortados no internódio 3 e 4 . Para cada tratamento, cada re petição foi composta de um colmo TT e um colmo RS.

\subsubsection{Hora de Corte da Muda}

Dez repetições da variedade CB41-76 sendo cada repetição composta de um colmo TT e um colmo RS, cortados às $8: 00 ; 11: 00 ; 13: 30$ e $15: 30$ horas foram utilizadas na determi nação da interferéncia da hora de corte da muda, na coloração do xilema.

\subsubsection{Tempo de Cavitação}

E o tempo gasto desde o recorte do colmo até a 
imersão na solução corante proporcionando a formação de espaço no xilema pela quebra da coluna de água. Para a avaliação do tempo de cavitação, nove colmos TT da variedade NA56-79, cor respondendo a nove repetições, foram analisadas nos tempos de $0-5,30,60,90$ e 120 segundos. Do mesmo modo, dez colmos TT e RS da variedade CB41-76, correspondendo a dez repetições foram analisados nos tempos de $0-5,30$ e 60 segundos.

\subsubsection{Corantes}

A eficiência dos corantes descritos no item 3.3 foi avaliada na determinação da percentagem mêdia de vasos co loridos em colmos de cana-de-açūcar. Para cada corante, foram analisados quinze colmos TT da variedade NA56-79, correspondendo a quinze repetições. Igualmente, na variedade CB4l-76 foram analisadas dez repetições, sendo cada repetição compos ta de um colmo TT e um colmo RS.

\subsubsection{Tempo de Coloração do Xilema}

E o tempo necessário para que o fluxo da corren te transpiratória no colmo succione a solução corante. Para isto, sete repetições da variedade CB41-76, sendo cada repeti ção composta de um colmo TT e um colmo RS, foram analisados nos tempos de $15,30,45$ e 60 minutos. Da mesma maneira, na variedade NA56-79 foram analisados nos mesmos tratamentos, no ve colmos TT, onde cada colmo correspondeu a uma repetição.

\subsubsection{Interferência de Brocas (Diatraea spp)}

Para a avaliação da interferença da broca loia traea sppl na coloração do xilema, pelo fluxo transpiratō 
rio, colmos da variedade NA56-79 tratadas termicamente (TT), pertencentes a viveiro primário com alta infestação de brocas, foram analisados conforme as amostras a seguir:

- Amostra 1: 66 colmos, sendo 32 apresentando perfurações da broca e 34 sem brocas.

- Amostra 2: 64 colmos, sendo 26 apresentando perfurações da broca e 38 sem brocas.

- Amostra 3: 20 touceiras indexadas, sendo analisado de cada touceira um colmo com e um sem perfurações de bro cas.

Os resultados obtidos em cada amostra foram sub metidos à análise de variāncia para comparação de médias em um delineamento estatístico inteiramente casualizado.

3.5.7. Umidade do Solo

$\mathrm{Na}$ determinação da influência da umidade so so10 na coloração do xilema, lançou-se mão das observações realizadas por ocasião da coleta dos resultados nos métodos de vazão de água, vazão de solução corante e de coloração do xilema pelo fluxo transpiratório, aplicados para se determi nar o estado de sanidade de colmo TT e RS e no controle de qua lidade de viveiros de cana-de-açúcar. Relacionaram-se os resultados obtidos em cada método com a quantidade de chuva em mm ocorrida no período das avaliações, (Apêndices 5 a 12).

3.6. Avaliação da Eficiência dos Três Métodos na Determina ção de Sanidade de Colmos Tratados Termicamente (TT) e Inoculados com Caldo Bruto (RS).

Para os métodos de vazão de ãgua, vazão de solu 
ção corante e de coloração do xilema pelo fluxo transpiratório foram empregadas as metodologias descritas nos itens 3.4.1., 3.4.2. e 3.4.3., respectivamente.

Para que houvesse uniformidade do material uti lizado nas avaliações, touceiras sadias (TT) e touceiras do entes (RS) foram divididas no mesmo número de colmos, para ca da mëtodo.

Os resultados obtidos em cada método foram sub metidos à anālise de variāncia, para comparação de médias no delineamento estatistico inteiramente casualizado, conforme Quadro 2.

3.6.1. Determinação da Vazão de Agua em Colmos Sadios (TT) e Doentes (RS)

As determinações foram feitas medindo-se o volu me da solução corante em ml durante 15 minutos, em vinte repe tições na variedade CB41-76 e vinte repetições na variedade NA56-79. Cada repeti.ção foi composta de quatro secções de col mos TT e quatro secções de colmos RS, distribuídos ao acaso nos oito bicos do fluxómetro.

3.6.2. Determinação da Porcentagem Média de Vasos Coloridos pelo Método de Vazão de Solução Coran te.

A percentagem média de vasos coloridos foi determinada aproveitando-se do material utilizado no item 3.6.1. Após a determinação da vazão da solução corante, as secções de colmos foram cortados transversalmente próximo a região do nó e avaliados através da escala de sintomas descrita no item 3.4.2.1. Foram avaliadas vinte repetições para cada variedade. 
3.6.3. Determinação da Percentagem Média de Vasos Co loridos, pelo Método de Coloração do Xilema pé 10 Fluxo Transpiratório.

Foram aṇalisadas vinte repetições na variedade CB41-76 e vinte repetições na variedade NA56-79. Cada repeti ção foi composta de quatro colmos inteiros TT e quatro colmos inteiros RS. Após o tempo de coloração de 60 minutos, os col mos foram cortados transversalmente no primeiro nó basal e avaliados atravēs da escala de sintomas descritano item 3.4.2.1.

3.6.4. Comparação entre os Métodos: Vazão de Solução Corante e de Coloração do Xilema pelo Fluxo Transpiratōrio, na Determinação de Sanidade e Colmos TT e RS.

Na comparação dos métodos citados, aproveitou-se dos resultados obtidos nos itens 3.6 .2 . e 3.6.3., respectiva mente.

3.7. Aplicação do Método de Coloração do Xilema pelo Fluxo Transpiratório, no Controle de Qualidade do Viveiros e Canaviais Comerciais de Cana-de-Açúcar.

Para aplicação deste método foram realizadas cin co amostragens, as quais, são descritas a seguir:

- Amostragem 1: 79 colmos da variedade IAC52-150 de viveiro se cundārio, com 13 meses de idade.

- Amostragem 2: 80 colmos da variedade NA56-79 de viveiro se cundário, com 13 meses de idade.

- Amostragem 3: 128 colmos da variedade NA56-79 de viveiropri märio, com 11 meses de idade, solo seco. 
- Amostragem 4: 66 colmos da variedade NA56-79 de viveiro prí mārio, com 11 meses de idade, solo úmido.

- Amostragem 5: 225 colmos da variedade NA56-79, campo comer cial de 20 corte, com 13 meses de idade.

\subsection{Anālise Estatística}

No quadro 1 e 2 encontram-se os esquemas da anā lise de variancia adotados para os ensaios com esquema fator al e inteiramente casualizado, respectivamente.

Quadro 1. Esquema da anālise de variância adotado para os en saios com esquema fatorial.

\begin{tabular}{lr}
\hline Causa de Variação & G.L. \\
\hline Primeiro fator (A) & $a-1$ \\
Segundo fator (B) & $b-1$ \\
Interação A $\mathrm{B}$ & $(a-1) \quad(b-1)$ \\
Resíduo & ab $(r-1)$ \\
\hline Total & abr - 1 \\
\hline
\end{tabular}

onde:

$a=$ nümero de niveis do primeiro fator,

$b=$ número de níveis do segundo fator;

$r=$ nūmero de repetições.

Para os casos em que o teste foi significativo, e tendo-se mais de dois tratamentos, a comparação entre as mé dias dos tratamentos foram feitas pelo teste de Tukey, ao nI vel de $5 \%$ de probabilidade. 


Quadro 2. Esquema da anālise de variāncia adotado para
sajos realizados no delineamento inteiramente
$\begin{aligned} & \text { lizado. } \\
& \text { Causa da Variação }\end{aligned}$
\begin{tabular}{ll} 
Tratamentos & G.L \\
Residuo & $t-1$ \\
\hline Total & $p-t$ \\
\hline
\end{tabular}

onde:

$t=$ nümero de tratamentos

$p=$ número total de parcelas existentes 
4. RESULTADOS

Os dados apresentados na forma de Tabelas sãodes tinadas a anāise de variāncia e teste de Tukey, para comparação de médias. Com exceção do método de vazão de āqua, apresen tado em volume ( $\mathrm{ml}$ ), os demais, foram obtidos através da esca1 a de sintomas (notas), descrita em 3.4.2.1. Para o fator altu ra de recorte do colmo a avaliação foi feita no $2 \subseteq$ e 40 nó e nos demais testes, sómente, no 40 nō, correspondendo ao primei ro nó basal colorido, para cada teste estudado. Estas notas transformadas em percentagem de vasos coloridos, são apresenta dos graficamente na forma de Figuras.

4.7. Padronização da Escala de Sintomas do RS pela Coloração do Xilema

Na Figura 1 são exemplificadas as variações das disfunções dos vasos do xilema, no nó de colmos de cana-de-açū car, representados pelas regiões escurecidas, as quais, foram classificadas de acordo com a escala de sintomas descrita em 3.4 .2 .1 . 


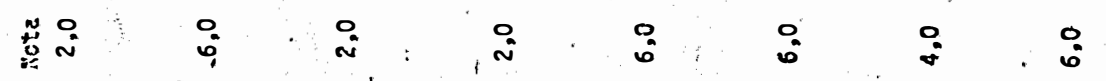

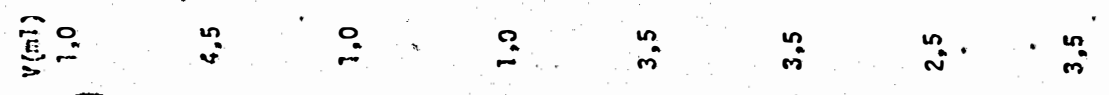

$\rightarrow$

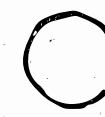

(6)
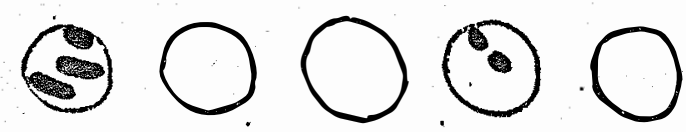

(

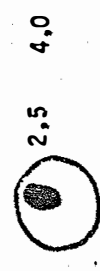

i.

is

$\stackrel{\circ}{\circ}$

o̊.

$\overbrace{0}^{i}$
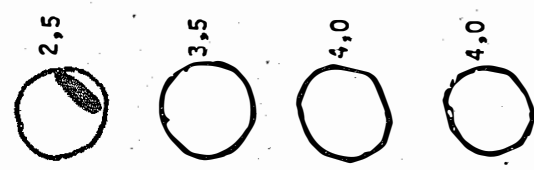

$\stackrel{0}{\circ} \stackrel{0}{\circ}$

요

o.

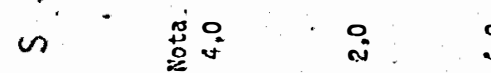

w

(1)

i.

ن

:

$\circ$

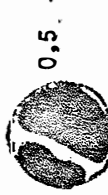

$\overbrace{}^{n}$

i

(2)

10

i

$\circ$

is

$0 \quad \frac{E}{5}$

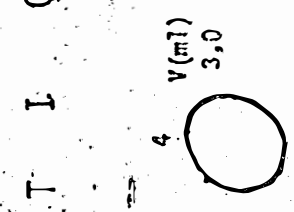

ni ni na

C

(i) j

$\stackrel{\circ}{\circ}$

n.

$\square^{i}$

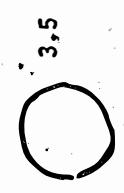

$\square^{\infty}$

$\overbrace{}^{n}$

$\square^{\infty}$

:

o.

is

宦品

(2)

$\stackrel{0}{i}$

$\stackrel{\circ}{\circ}$

\& $\quad$ in

$\stackrel{0}{i}$

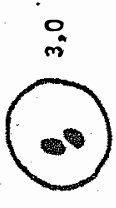

$\stackrel{n}{+}$

$\overbrace{0}^{\circ}$

is

in

i

:

in

i

$\alpha$

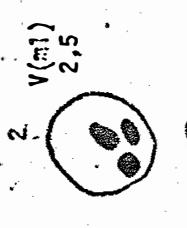

(1)
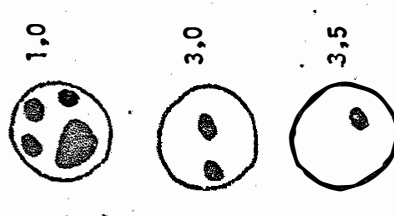

in

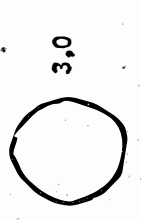

$\stackrel{0}{0}$

웅
n
in
0
$>$

음

a

兽

ơ

i

0 要

थี

$\operatorname{lin}_{0} \stackrel{x}{2}$

i⿱ 2

웅 $\frac{0}{0}$

$\begin{array}{ll}0 & 0 \\ \text { c } & 0\end{array}$

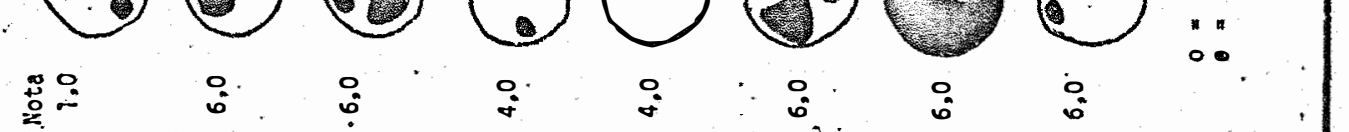

(20)
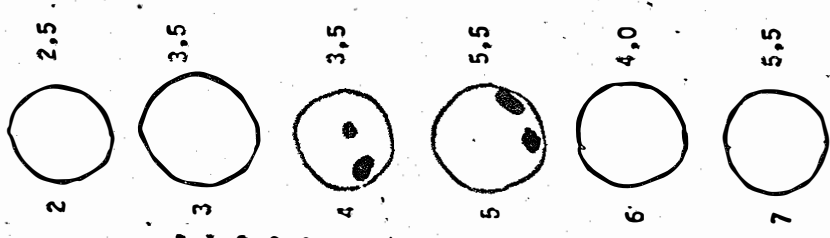

$\overbrace{\infty}^{\substack{n \\+}}$

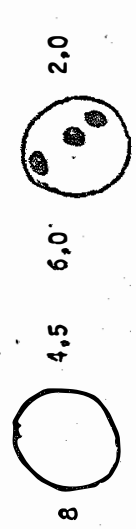

.

B.ICOS DP FLUXONETRO

. 
A Figura 2 apresenta os padrões gráficos do indi de de contaminação do RS (disfunção dos vasos do xilema), eleborados de acordo com os resultados da Figura 1.

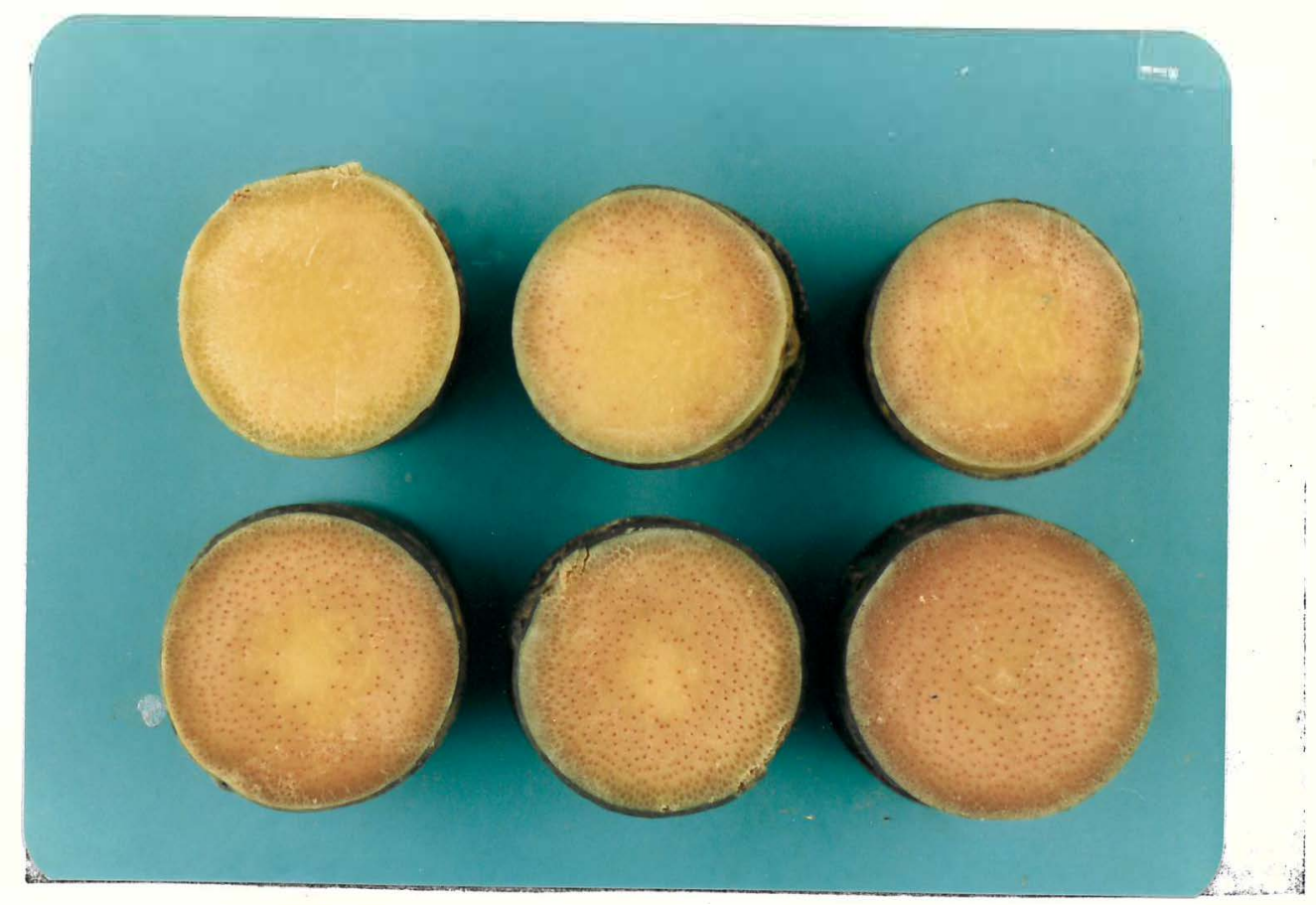

Superior: esquerda para a direita nota 1,2 e 3. Inferior: esquerda para a direita nota 4,5 e 6.

Figura 2. Escala padrão de sintomas do RS, onde a nota 1 equivale a $16,33 \%$ e 6 equivale a $100 \%$ de vasos coloridos.

4.2. Tempo Minimo Necessärio na Coloração do Xilema, delo Mé todo de Vazão de Solução Corante.

A Tabela 1 , apresenta as notas médias e respecti vas percentagens de vasos coloridos, na região do nó de colmos TT e RS.

A anālise de variāncia não acusou diferenças sig nificativas, ao nīvel de $5 \%$ de probabilidade, pelo teste F, na ra tempos de coloração. Porēm, acusou diferenças significativas, 
ao nivel de $1 \%$ de probabilidade pelo teste $F$, para sanidade.

Tabela 1. Notas médias e percentagens de vasos coloridos na va riedade NA56-79 tratada termicamente (TT) e inoculada com caldo bruto (RS); julho/84.

\begin{tabular}{cccccc}
\multirow{2}{*}{$\begin{array}{c}\text { Tempos de colo } \\
\text { ração (minutos) }\end{array}$} & \multicolumn{2}{c}{ Notas Médias em 10 Repetições } \\
\cline { 2 - 3 } \cline { 5 - 6 } & Notas & Coloridos $(\%)$ & Notas & Coloridos (\%) \\
\hline 2 & $4,70 \mathrm{a}$ & 78,33 & & Rasos \\
\hline 4 & $4,70 \mathrm{a}$ & 78,33 & & $2,70 \mathrm{~b}$ & 36,67 \\
6 & $5,20 \mathrm{a}$ & 86,67 & & $2,90 \mathrm{~b}$ & 45,00 \\
8 & $5,10 \mathrm{a}$ & 85,00 & & $2,50 \mathrm{~b}$ & 48,33 \\
& & &
\end{tabular}
C.V. $=32,27 \%$
d.m.s. $(5 \%)=0,54$

Médias com letras iguais não diferem estatisticamente entre si.

4.3. Fatores que interferem no Método de Coioração do Xilema pelo fluxo Transpirátório.

4.3.1. Altura de recorte do colmo.

As notas médias transformadas em percentagem de vasos coloridos, são apresentados na Figura 3 .

A Tabela 2 , resgistra as notas médias e respecti vas percentagens de vasos coloridos no 20 e 40 nó, de colmos TT e RS.

A anālise de variāncia apresentou diferenças sig nificativas, ao nível de $1 \%$ de probabilidade, pelo teste $F$, pa ra altura de recorte do colmo e sanidade. Porém, não apresentou diferença significativa, ao nível de $5 \%$ de probabilidade, para a interação desses fatores. 


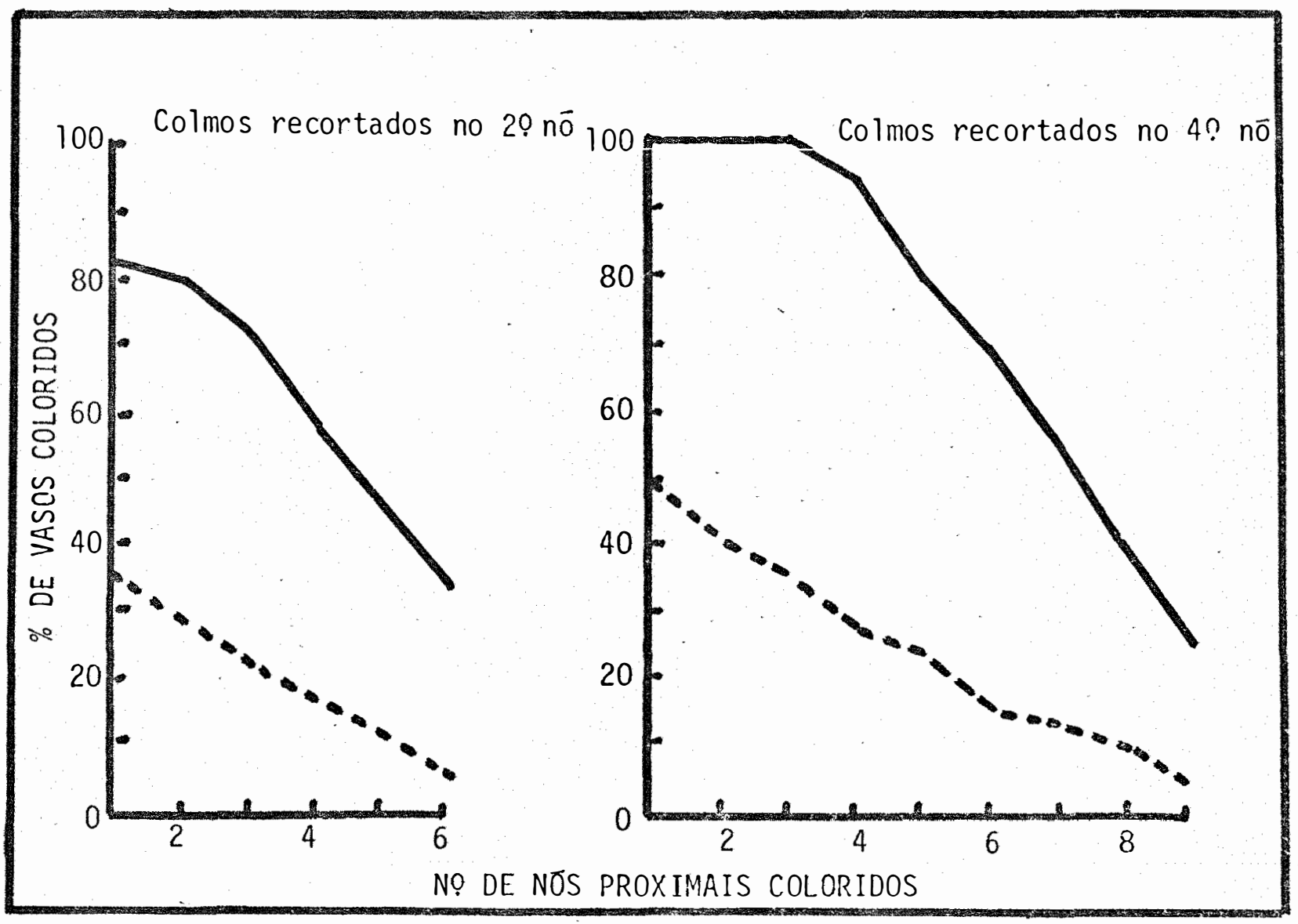

Figura 3. Efeito da altura de recorte para eliminação da cavi tação, dos vasos, variedade CB41-76, média de 10 repetições de colmos Tratados Termicamente (TT, e inoculados com caldo bruto (RS, .....). 
Tabela 2. Notas médias e percentagens de vasos coloridos na va riedade CB41-76 tratada termicamente (TT) e inoculada com caldo bruto (RS); setembro/84.

\begin{tabular}{|c|c|c|c|c|}
\hline \multirow{4}{*}{$\begin{array}{l}\text { Altura de recorte } \\
\qquad(\text { nó) }\end{array}$} & \multicolumn{4}{|c|}{$\begin{array}{l}\text { Valores mēdios em } 10 \text { repetições obtidos } \\
\text { no } 19 \text { : nö basal colorido }\end{array}$} \\
\hline & \multicolumn{2}{|c|}{ TT } & \multicolumn{2}{|c|}{ RS } \\
\hline & & Vasos & & Vasos \\
\hline & Notas & $\begin{array}{c}\text { Coloridos } \\
(\%)\end{array}$ & Notas & $\begin{array}{c}\text { Coloridos } \\
(\%)\end{array}$ \\
\hline 20 & A4, 90a & 81,67 & $A 2,10 b$ & 35,00 \\
\hline 40 & $\mathrm{~B} 6,00_{\mathrm{a}}$ & 100,00 & B 3,00b & 50,00 \\
\hline
\end{tabular}

Médias com letras iguais não diferem estatisticamente entre si.

4.3.2. Hora de Corte da Muda.

A Figura 4, apresenta as notas médias transforma das em percentagens de vasos coloridos, referente as mudas cortadas às $8: 00 ; 11: 00 ; 13: 30$ e 15:30 horas.

As notas médias e percentagens de vasos coloridos, de colmos TT e colmos RS, encontram-se na Tabela 3.

A anālise de variância acusou diferenças sig̣nifi cativas, ao nivel de $1 \%$ de probabilidade, pelo teste $F$, para hora de corte da muda e sanidade. No entanto, não houve diferença significativa ao nivel de $5 \%$ de probabilidade, para a in teração desses fatores. 


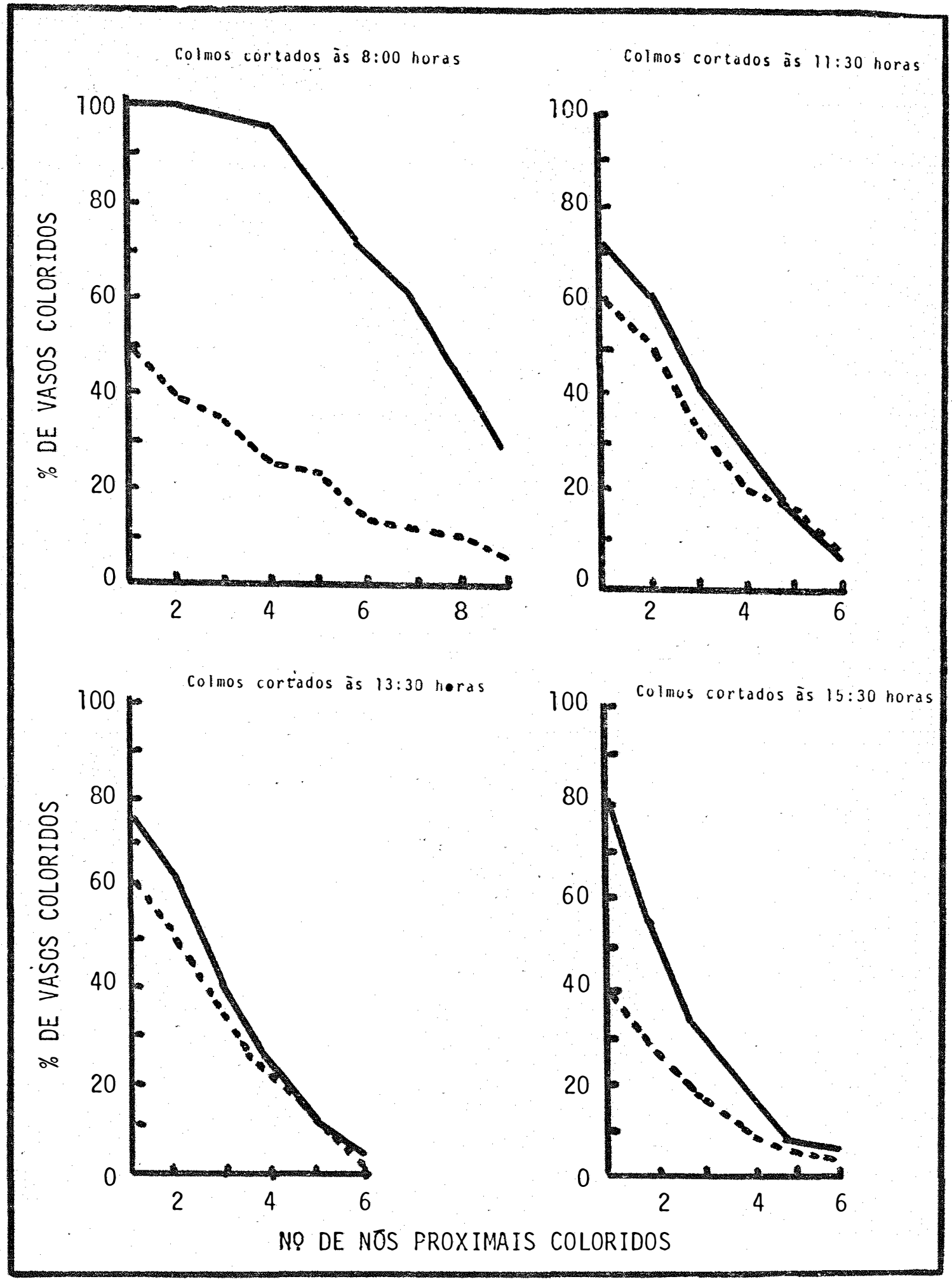

Figura 4. Efeito da hora de corte para eliminação da cavitação dos va sos, variedades CB41-76, 10 repetições de colmos Tratados Termicamente ( $T T$, ) e inoculados com caldo bruto (RS, -...-). 
Tabela 3. Notas médias e percentagens de vasos coloridos na va riedade CB41-76 tratada termicamente (TT) e inoculada com caldo bruto (RS); setembro/84.

\begin{tabular}{|c|c|c|c|c|}
\hline \multirow{4}{*}{$\begin{array}{l}\text { Hora de Corte } \\
\text { das Mudas }\end{array}$} & \multicolumn{4}{|c|}{$\begin{array}{l}\text { Valores médios de } 10 \text { repetições obtidos } \\
10 \text { nö basal coloridos }\end{array}$} \\
\hline & \multicolumn{2}{|c|}{$\mathrm{TT}$} & \multicolumn{2}{|c|}{ RS } \\
\hline & & Vasos & & Vasos \\
\hline & Nota & $\begin{array}{c}\text { Coloridos } \\
(\%)\end{array}$ & Nota & $\begin{array}{l}\text { Coloridos } \\
(\%) \\
\end{array}$ \\
\hline $8: 00$ & $A 6,00 a$ & 100,00 & $A B 3,00 B$ & 50,00 \\
\hline $11: 00$ & $B 4,30 a$ & 71,67 & B3, $60 \mathrm{~b}$ & 60,00 \\
\hline $13: 30$ & $B 4,60 a$ & 76,67 & $B 3,70 b$ & 61,67 \\
\hline $15: 30$ & $B 4,50 a$ & 75,00 & $\mathrm{~A} 2,40 \mathrm{~b}$ & 40,00 \\
\hline
\end{tabular}

C.V. $=23,19 \% ;$ d.m.s. $(5 \%) A, B=0,77 ;$ d.m.s. $(5 \%) a, b=0,41$

Letras maiūsculas comparam duas médias de hora de corte dentro de cada sanidade, onde médias com letras iguais não diferem es tatisticamente entre si.

Letras minúsculas comparam duas médias de sanidade dentro de ca da hora de corte, onde médias com. letras iguais não diferem es tatisticamente entre si. 


\subsubsection{Tempo de Cavitação.}

Nas Figuras 5 e 6 , são apresentados os resultados médios transformados em percentagem de vasos coloridos nos tem pos de cavitação de $0-5,30,60,90$ e 120 e $0-5,30$ e 60 segun dos, respectivamente.

As Tabelas 4 e 5 , apresentam as notas médias e percentagens de vasos coloridos, em colmos das variedades NA5679 TT e CB41-76 TT e RS, respectivamente.

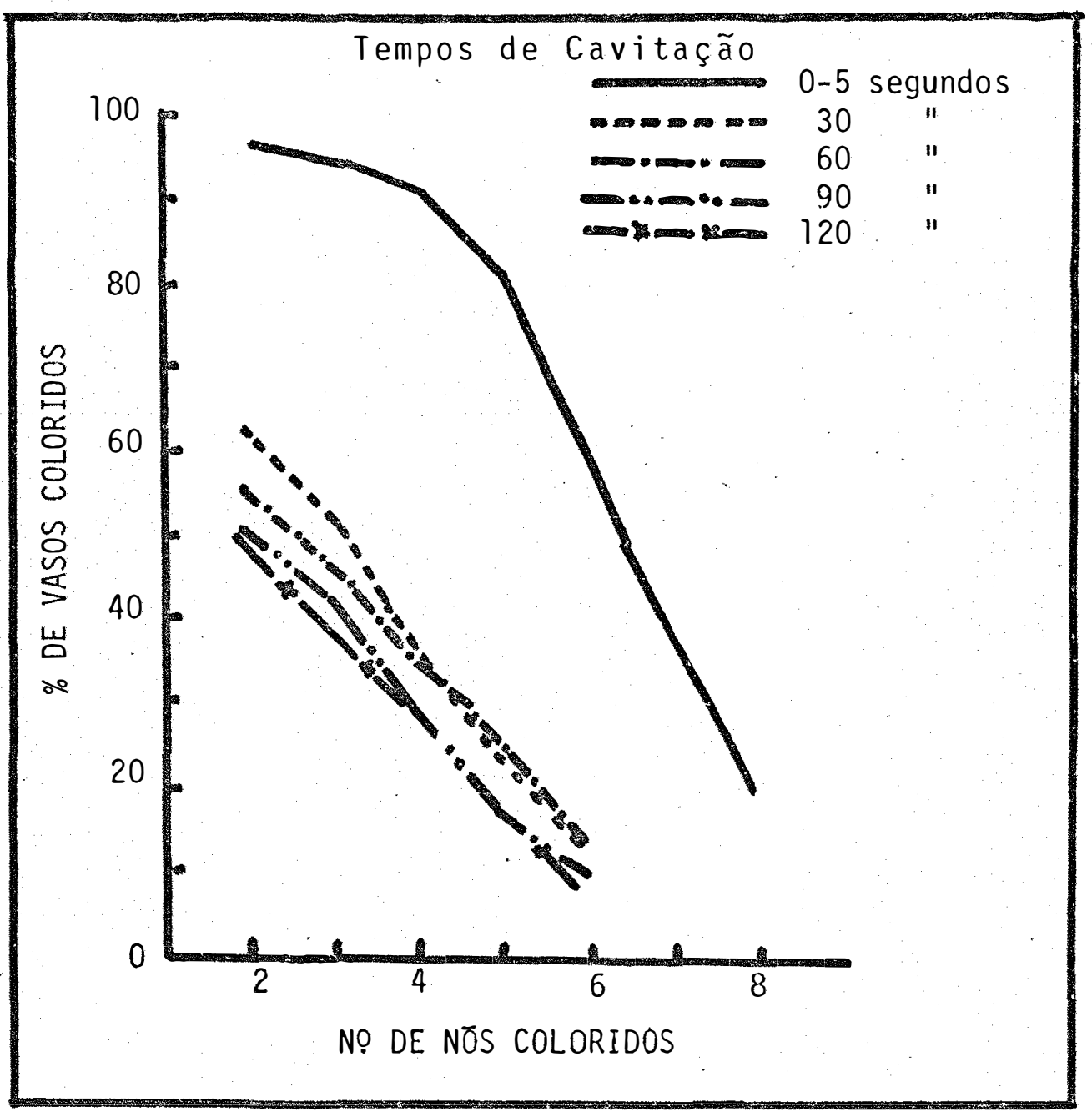

Figura 5. Percentagem média de vasos coloridos em colmos tra tados termicamente (TT) submetidos a tempos de cavitação, média de 9 repetições. 

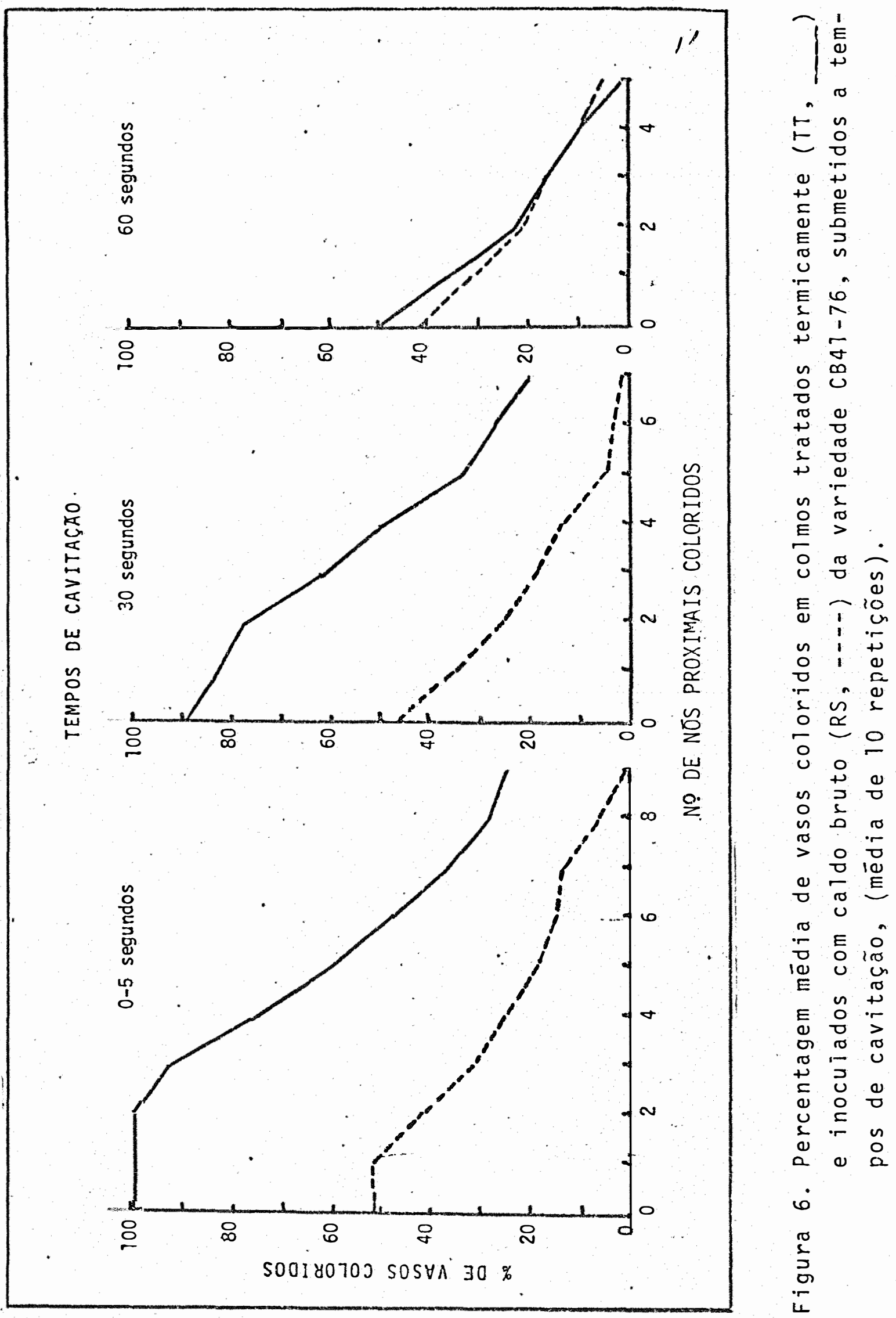
Para os valores da Tabela 4, a anālise de variān cia indicou $F$ significativo, ao nivel de $1 \%$ de probabilidade, para tempo de cavitação. A diferença mīnima significativa (d.m .s.) ao nível de $5 \%$ de probabilidade, foi de 0,47 .

Tabela 4. Notas médias e percentagens de vasos coloridos na va riedade NA56-79 tratada termicamente (TT); abril/84.

Tempo de Cavitação (segundos)
Valores mēdios em 9 repetições obtidos no 1 @ nō basal colorido Notas Vasos Coloridos $(\%)$ 96,67 61,83 58,50 50,33 49,17

C.V. $=9,31 \%$

d.m.s. $(5 \%)=0,47$

Médias com letras iguais não diferem estatisticamente entresi.

Para os resultados da Tabela 5 , a anālises de variância acusou diferenças significativas, ao nível de $1 \%$ de pro babilidade, pelo teste $F$, para tempos de cavitação, sanidade e interação entre eles. 
Tabela 5. Notas médias e percentagens de vasos coloridos na va riedade CB41-76 tratada termicamente (TT) e inoculada com caldo bruto (RS); setembro/84.

\begin{tabular}{|c|c|c|c|c|c|}
\hline \multirow{2}{*}{$\begin{array}{l}\text { Tempos de Cavita- } \\
\text { ção (Segundos) }\end{array}$} & \multicolumn{5}{|c|}{$\frac{\text { Notas médias em } 10 \text { repetições/tratamento }}{\text { TT }}$} \\
\hline & Nota & $\begin{array}{c}\text { Vasos } \\
\text { Coloridos } \\
(\%)\end{array}$ & & Nota & $\begin{array}{l}\text { Coloridos } \\
\text { (\%) }\end{array}$ \\
\hline $0-5$ & A 6,00 a & 100,00 & A & $3,10 b$ & 51,67 \\
\hline 30 & B 5,30 a & 88,33 & A & $2,80 \quad b$ & 46,67 \\
\hline 60 & C 3,00 a & 50,00 & A & $2,50 \mathrm{~b}$ & 41,67 \\
\hline
\end{tabular}

Letras maiūsculas comparam duas médias de tempo de cavitação dentro de cada sanidade, onde médias com letras iguais não diferem estatisticamente entre si.

Letras minúsculas comparam duas médias de sanidade dentro de ca da tempo de cavitação, onde médias com letras iquais não dife rem estatisticamente entre si.

\subsubsection{Corantes.}

As Figuras 7 e 8 , apresentam as notas média trans formadas em percentagens de vasos coloridos nas variedades NA56 -79 e CB41-76, respectivamente. As Figuras 9 e 10 mostram na va riedade NA56-79 TT, a frequência de notas, em percentagem, para colmos testados com as soluções corantes saframina 0 e Vermelho 145 , respectivamente.

As notas médias e percentagens de vasos coloridos nas variedades NA56-79 TT e CB41-76 TT e RS, São apresentadas nas Tabelas 6 e 7 , respectivamente.

Para os resultados da Tabela 6 , a anālise de variància acusou diferença significativa, ao nivel de $1 \%$ de pro- 
babilidade, pelo teste $F$, para corante. Os resultados da Tabe1 a 7 , não apresentaram diferenças significativas, ao nível de $5 \%$ de probabilidade, para corantes, porém, acusaram diferenças significativas, ao nivel de $1 \%$ de probabilidade, pelo teste $F$, para sanidade.

Tabela 6. Notas médias e percentagem de vasos coloridos na variedade NA56-79 tratada termicamente (TT), abril/1984.

\begin{tabular}{lcc}
\hline & Notas médias de 15 repetições/tratamento \\
Corantes & Nota & Vasos Coloridos \\
& & $(\%)$ \\
\hline Safranina 0 & 5,50 a & 91,67 \\
Vermelho C 2 & 5,20 a & 86,67 \\
Vermelho 145 & 4,40 b & 73,33 \\
\hline C.V. $=17,26 \%$ & d.m.s. $(5 \%)=0,77$ &
\end{tabular}

Tratamentos com letras iguais não diferem estatisticamente entre si.

Tabela 7. Notas médias e percentagens de vasos coloridos na va riedade CB41-76 tratada termicamente (TT) e inoculada com caldo bruto (RS); setembro/84.

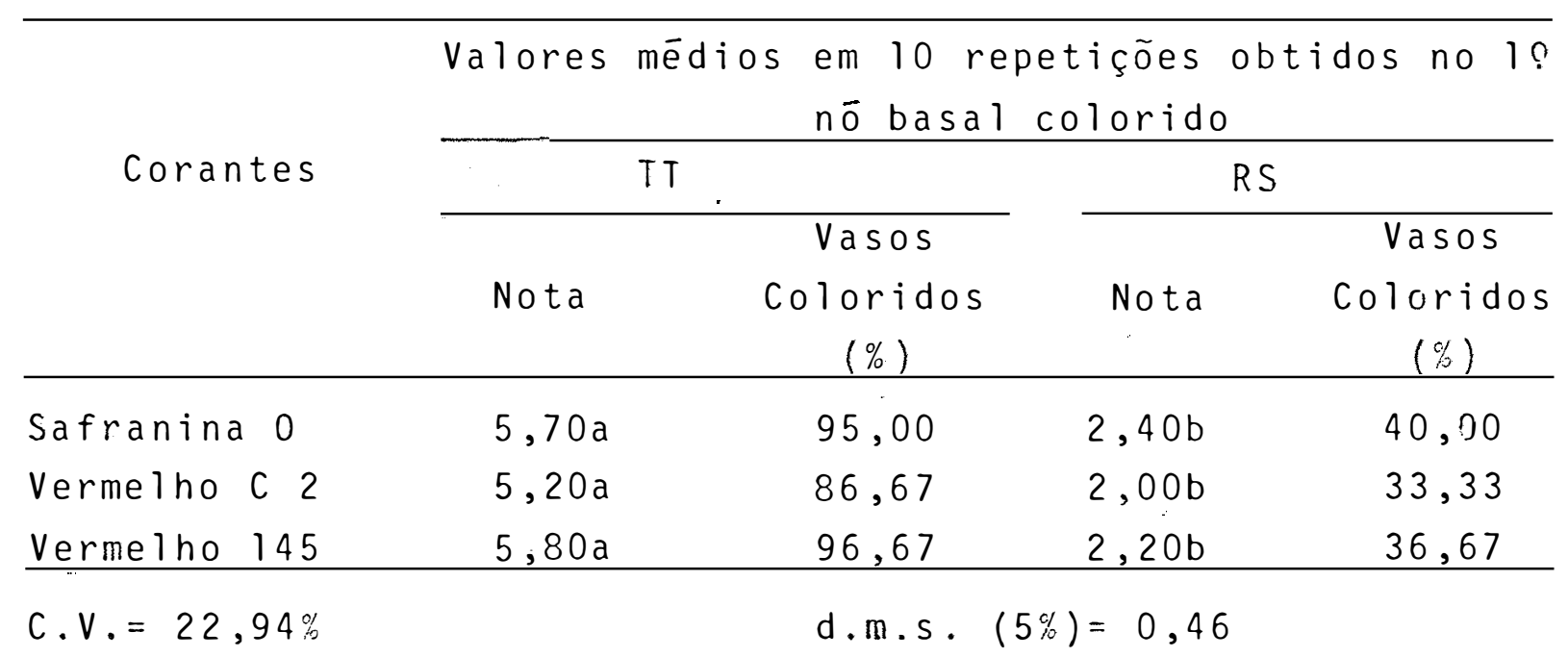

Médias com letras iguais não diferem estatisticamente entre si. 


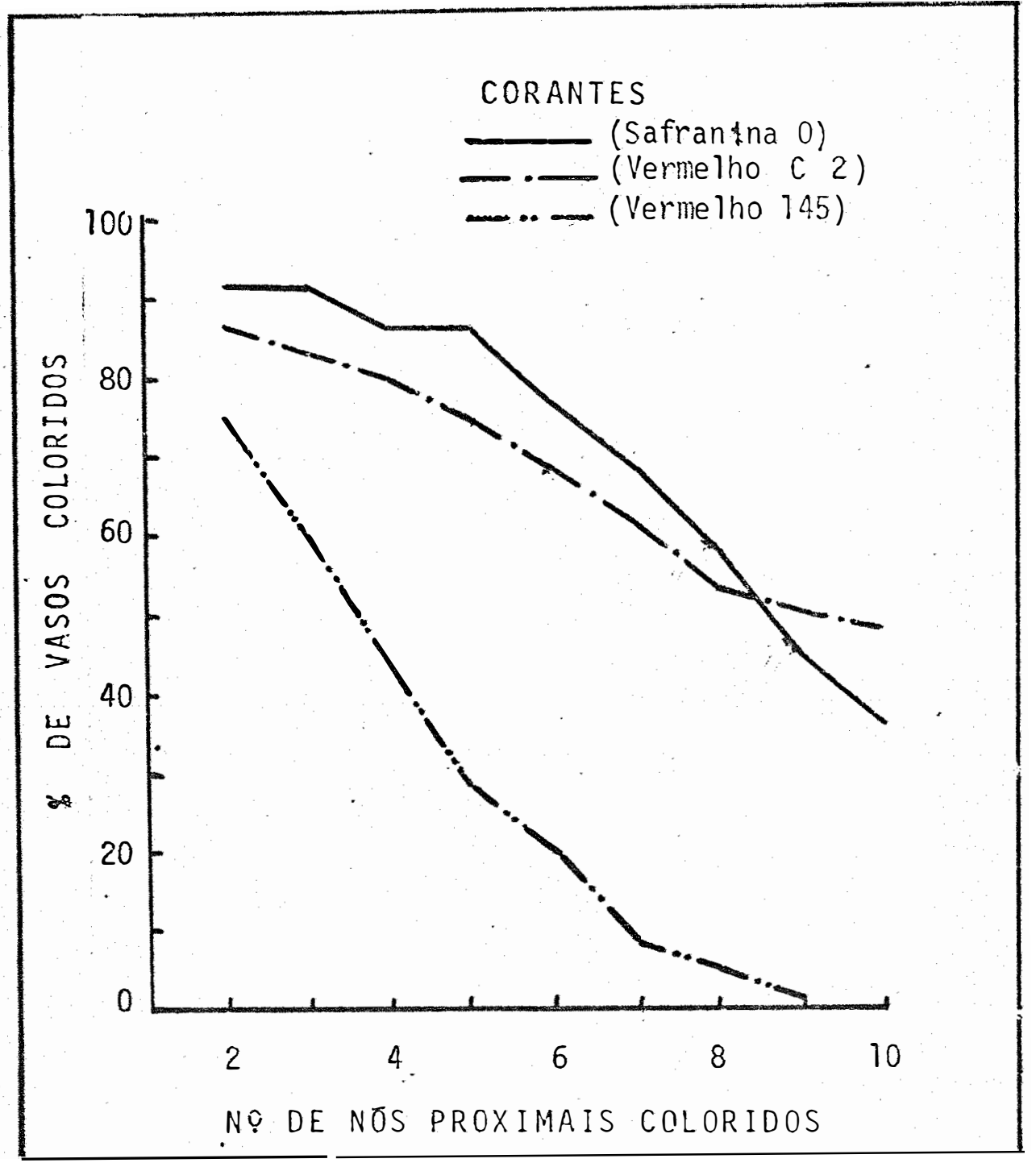

Figura 7. Eficiência de corantes avaliados pela \% de vasos coloridos na variedade NA56-79 tratada termica mente (TT) média de 15 repetições). 

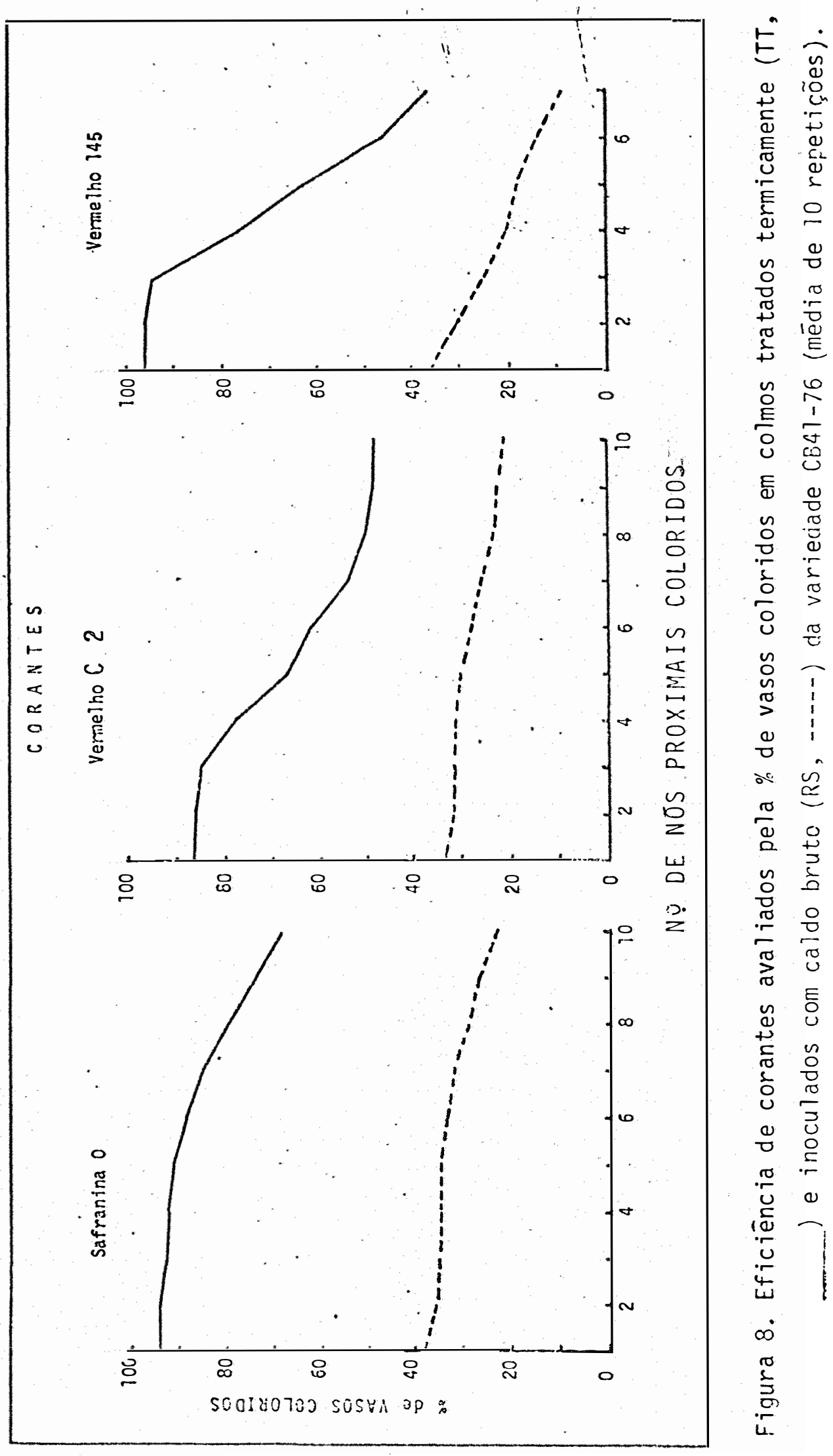


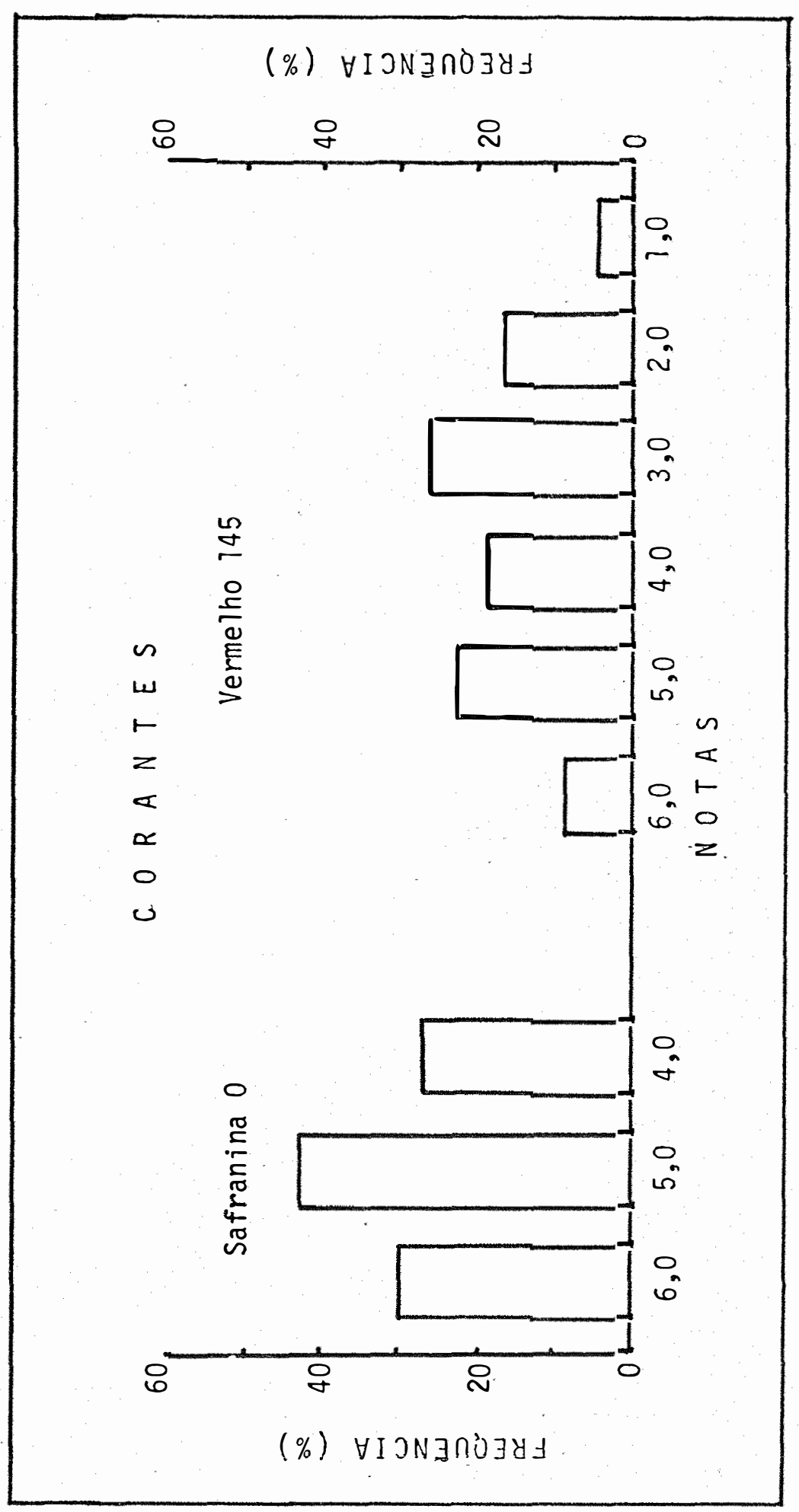

$\stackrel{\infty}{>}$

$\sigma$

들

a

+

들

0

రo

.

ᄃ

10

c

0

0

$\circ 5$

or

$\frac{0}{0} \stackrel{0}{0}$

2 $ᄃ$

$\sim$ ह

은

.

$\pi \frac{1}{\pi}$

$>+$

r

(1) ర

$+\infty$

1)

임

u o

(1) 1

- 6

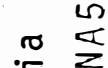

.r 2

당

100

$\because \frac{0}{4}$

ir $\frac{0}{4}$

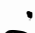

or

0
5
0

证 


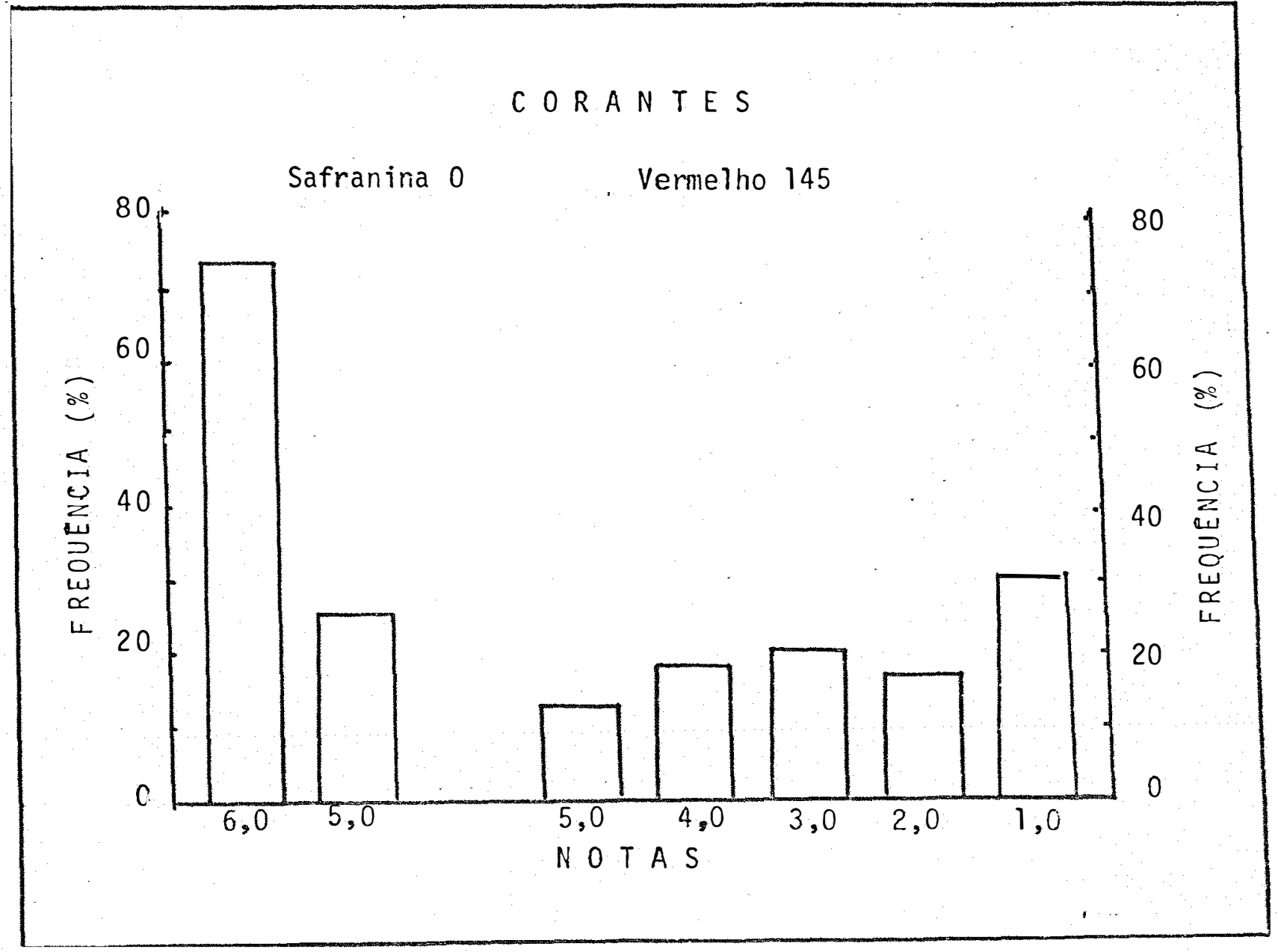

Figura 10. Eficiência de corantes avaliados pela \% de ocorréncia de notas na variedade NA56-79 tratada termi camente (TT). 


\subsubsection{Tempo de Coloração do Xilema.}

Na Figura 11 , são apresentados os resultados médios transformados em percentagens de vasos coloridos, nos tem pos de $15,30,45$ e 60 minutos.

As notas médias e respectivas percentagens de va sos coloridos nas variedades NA56-79 TT e CB41-76 TT e RS, encontram-se nas Tabelas 8 e 9 , respectivamente.

As anālises de variāncia acusaram diferenças sig nificativas, ao nível de $1 \%$ e $5 \%$ de probabilidade, pelo teste F, para tempo de coloração das Tabelas 8 e 9 , respectivamente. 


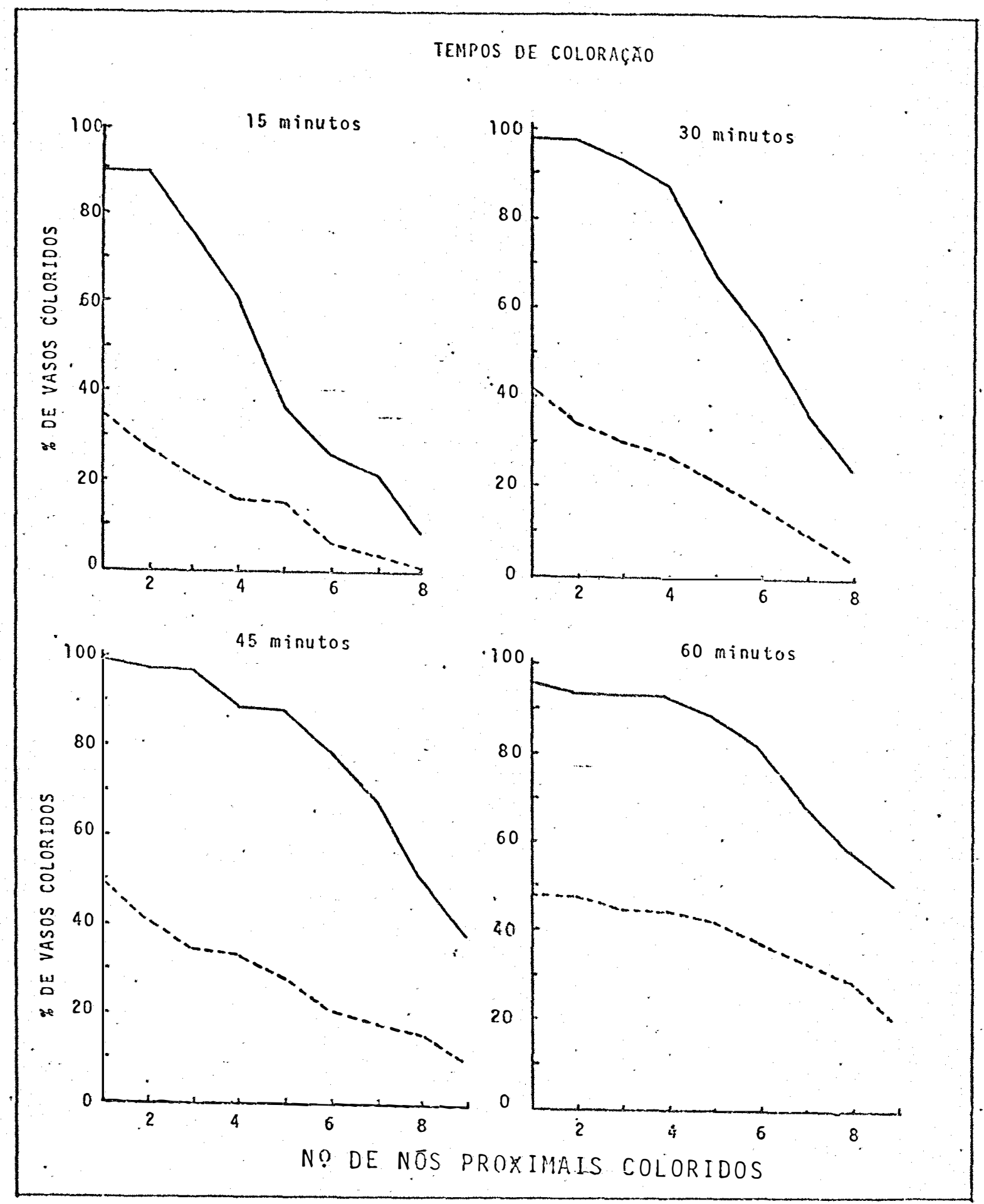

Figura 11. Percentagem média de vasos coloridos em colmos tratados termicamente ( $T T$, ) e inoculados com caldo bruto (RS, -...-) da variedade CB47-76 (média de 7 repetições). 
Tabela 8. Notas médias e percentagens de vasos coloridos na va riedade NA56-79, viveiro secundārio, solo seco, abril 184 .

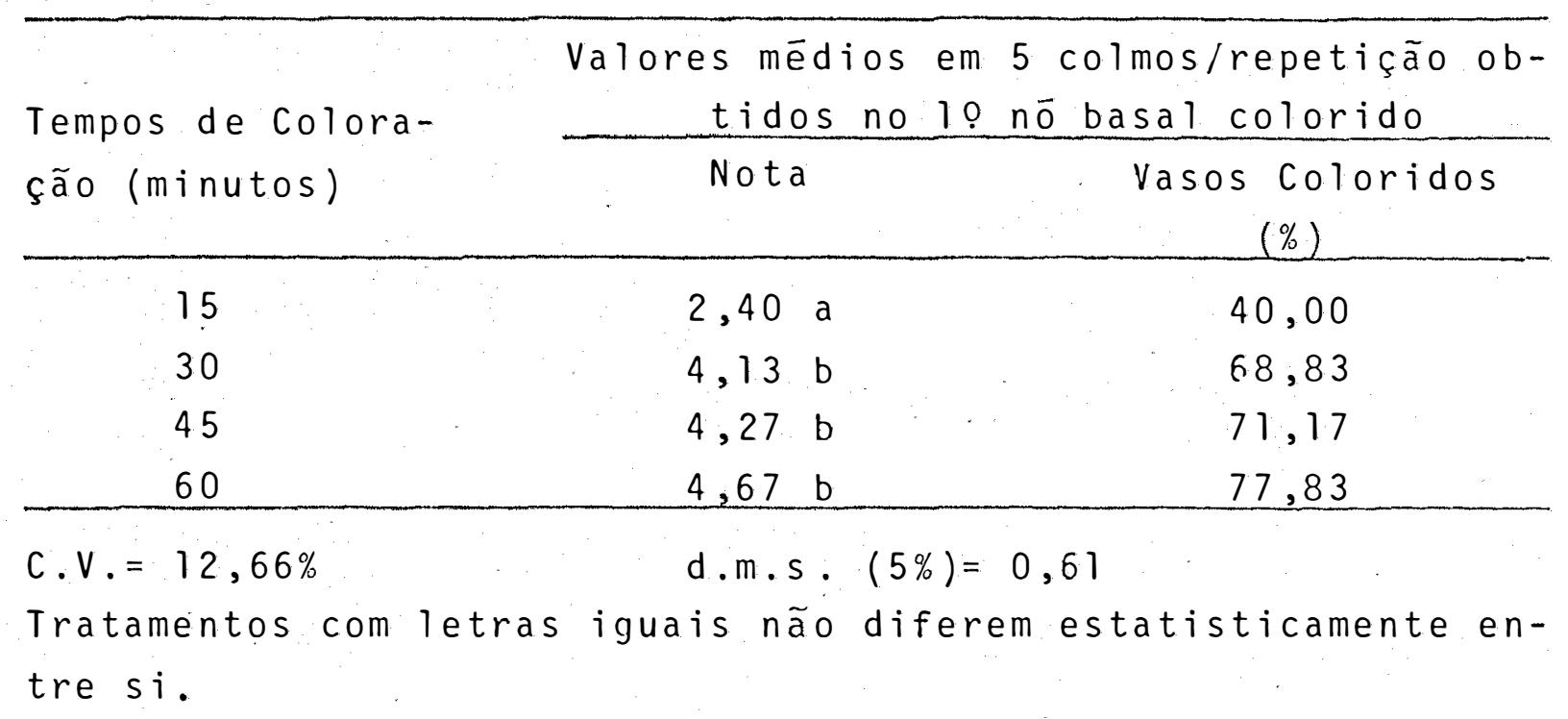

Tabela 9. Notas médias e percentagens de vasos coloridos na va riedade CB41-76 tratada termicamente (TT) e inoculada com caldo bruto (RS); setembro/84.

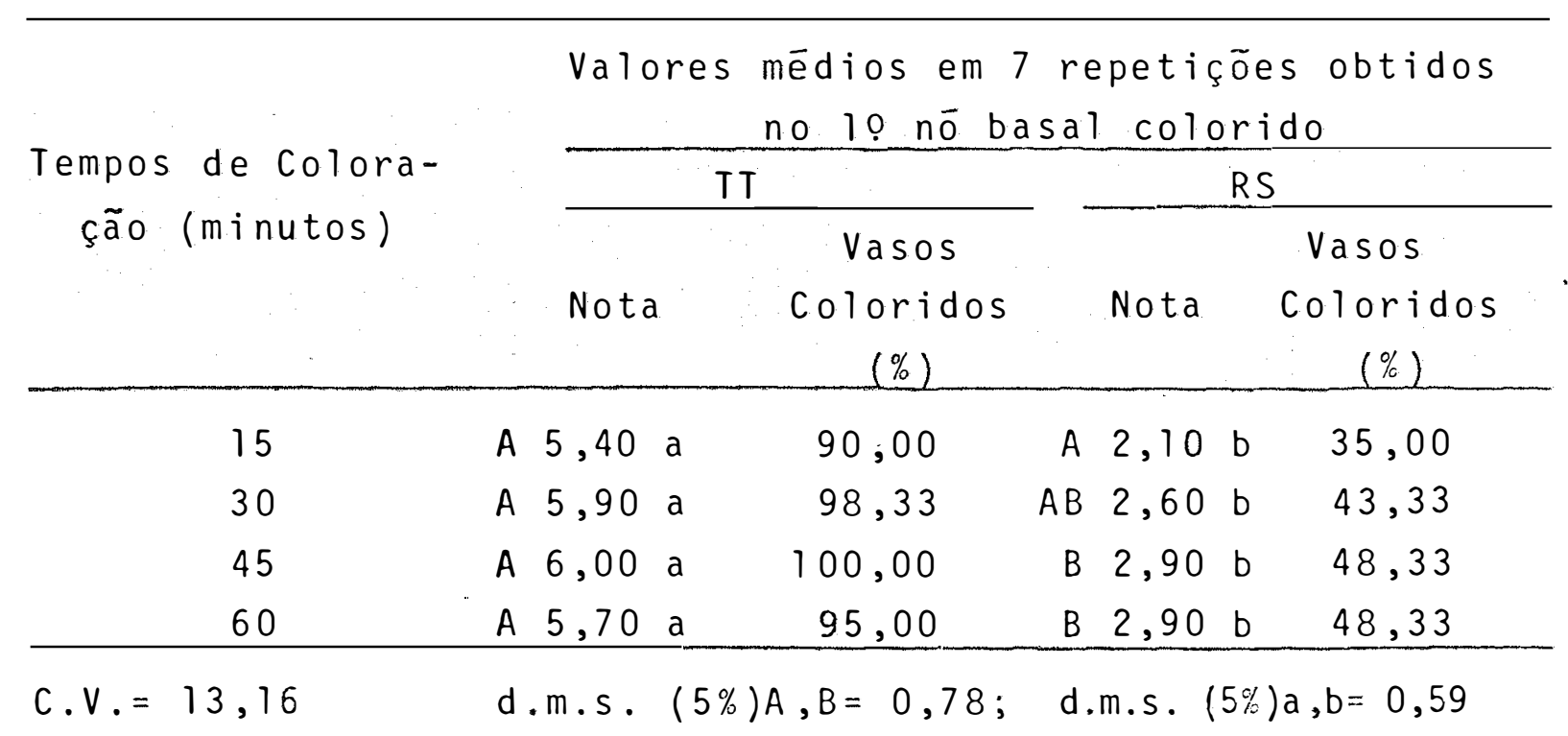


Letras maiūsculas comparam duas médias de tempo de coloração dentro de cada sanidade, onde médias com letras iguais não diferem estatisticamente entre si.

Letras minúsculas comparam duas médias de sanidade dentro de ca da tempo de coloração, onde médias com letras iguais não diferem estatisticamente entre si.

\subsubsection{Ataque de Broca (Diatraea spp).}

As notas médias transformadas em percentagens de vasos coloridos no quarto nó das amostras descritas em 3.5.7., são apresentados na Figura 12.

As notas médias e respectivas percentagens de va sos coloridos, das amostras descritas em 3.5.7., são apresenta dos na Tabela 10.

A anālise de variāncia acusou diferenças signifi cativas, pelo teste $F$, ao nivel de $1 \%$ de probabilidade, para os resultados da Tabela 10 . 


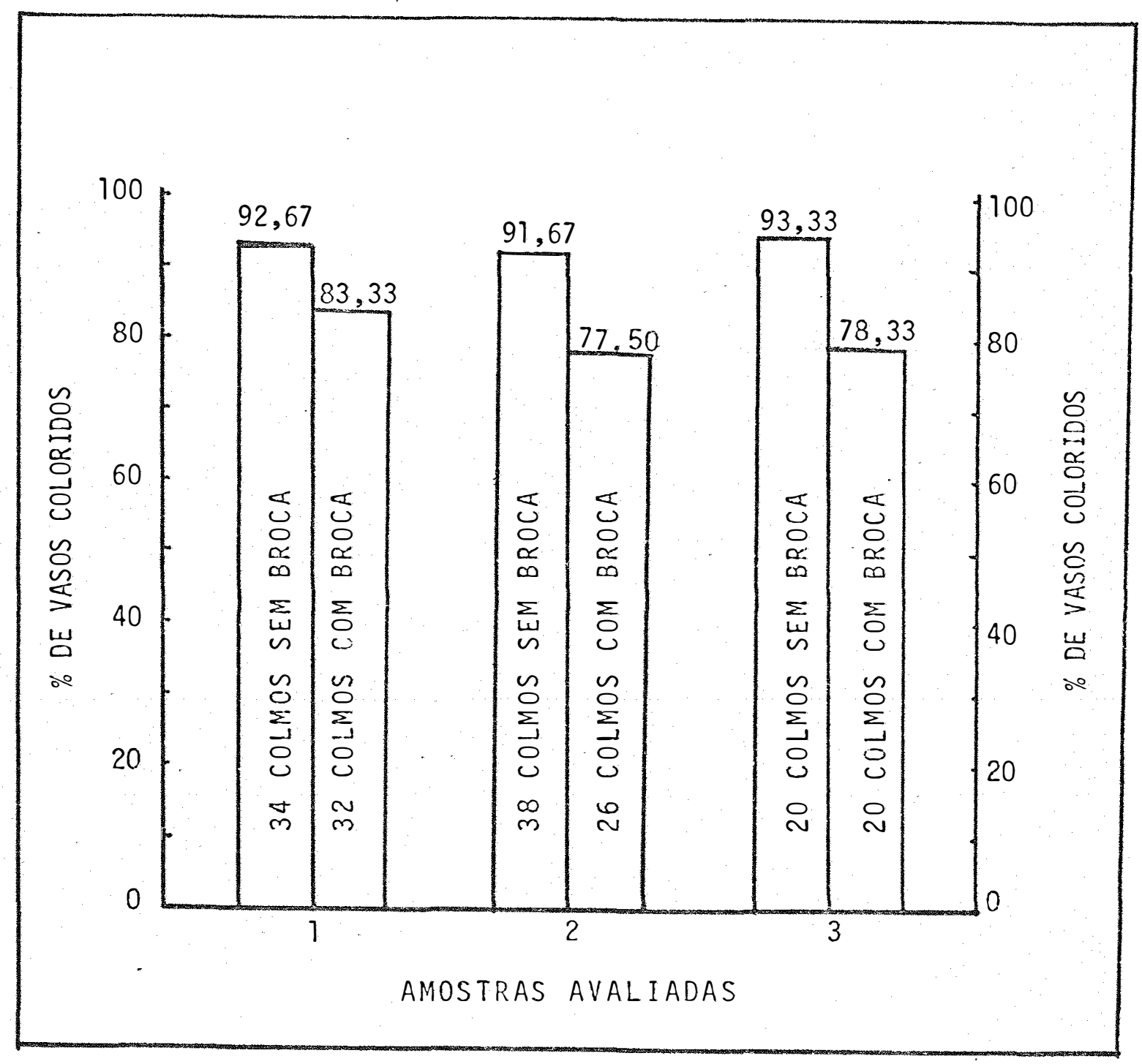

Figura 12. Inteferência da broca (Diatraea spp) na coloração do xilema avaliada pela percentagem de vasos coloridos na variedade NA56-79 tratada termicamente (TT). 
Tabela 10. Interferēncia da Broca (Diatraea spp) na Coloração do xilema, avaliada pela percentagem de vasos coloridos na variedade NA56-79 tratada temicamente (TT).

\begin{tabular}{|c|c|c|c|c|c|}
\hline Brocas & $\begin{array}{l}\text { Total de } \\
\text { Colmos }\end{array}$ & Nota & $\begin{array}{c}\text { Vasos } \\
\text { Coloridos (\%) }\end{array}$ & $\begin{array}{l}\text { C.V. } \\
(\%)\end{array}$ & $\begin{array}{r}\text { d.m.s. } \\
(5 \%)\end{array}$ \\
\hline \multicolumn{6}{|c|}{ AMOSTRA 1} \\
\hline SEM & 34 & $5,60 a$ & 93,33 & 14,18 & 0,37 \\
\hline COM & 32 & $4,70 \mathrm{~b}$ & 78,33 & & \\
\hline \multicolumn{6}{|c|}{ AMOSTRA 2} \\
\hline SEM & 38. & $5,50 a$ & 91,67 & 12,79 & 0,34 \\
\hline $\mathrm{COM}$ & 26 & $4,65 \mathrm{~b}$ & 77,50 & & \\
\hline \multicolumn{6}{|c|}{ AMOSTRA 3} \\
\hline SEM & 20 & $5,60 a$ & 93,33 & 14,37 & 0,48 \\
\hline COM & .20 & $4,65 b$ & 77,50 & & \\
\hline
\end{tabular}

Médias com letras iguais não diferem estatisticamente entresi.

4.4. Avaliação da Eficiēncia dos Três Métodos na Determinação de Sanidade de Colmos Tratados Termicamente (TT) e Inoculados com Caldo Bruto (RS).

4.4.1. Determinação da Vazão de Aqua em Colmos TT e RS.

As notas mëdias de vazão de āgua nas variedades CB41-76 e NA56-79, encontram-se nas Tabelas 11 e 12, respectiva mente.

Na Tabela 11 , a anālise de variāncia acusou diferenças significativas, ao nível de $1 \%$ de probabilidade, pelo teste $F$, para os resultados do experimento 1 e $5 \%$ de probabili dade, para os resultados do experimento 2. No entanto, para os experimentos 1 e 2 da Tabela 12 , o teste $F$ foi significativo, ao nivel de $1 \%$ de probabilidade. 


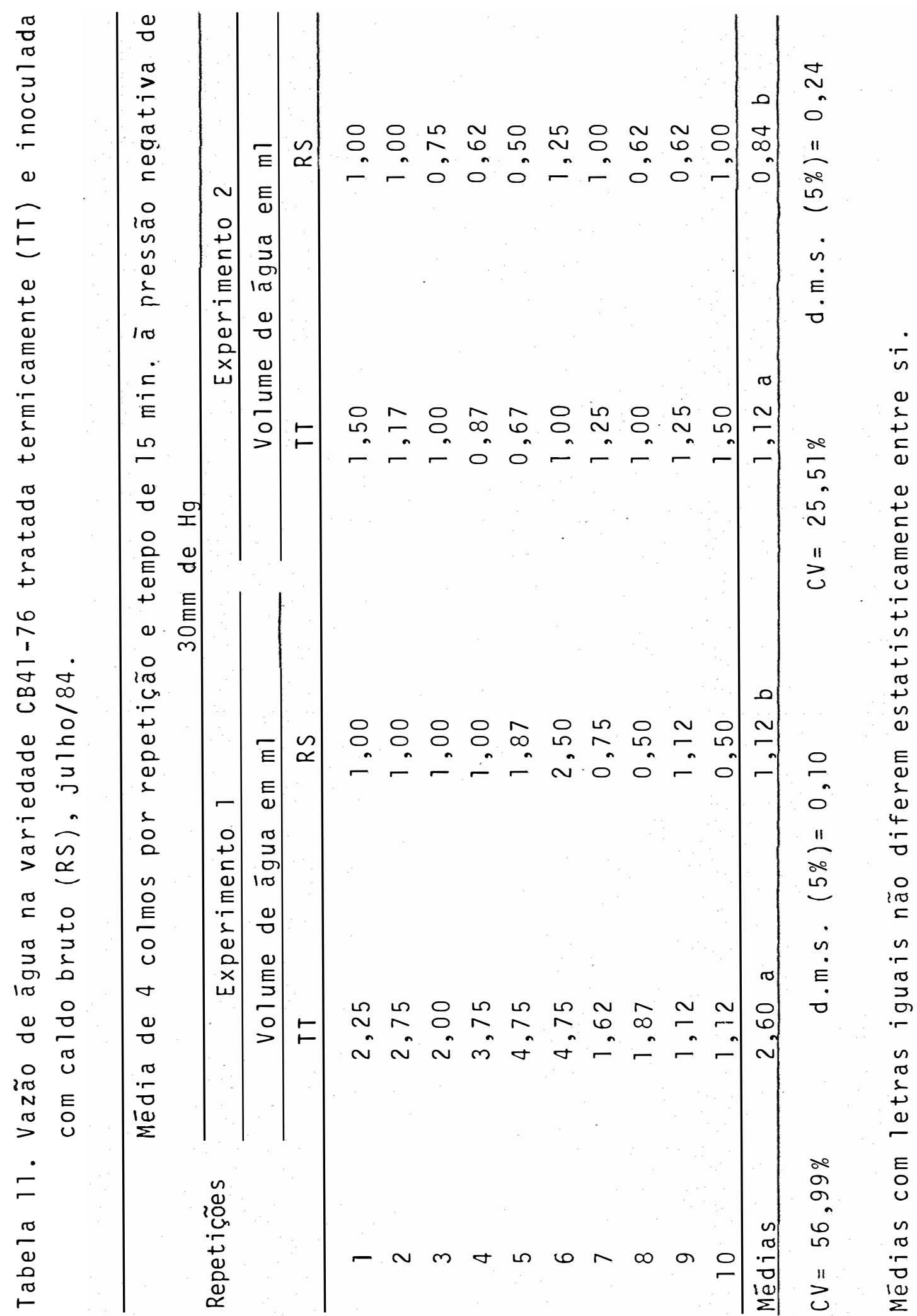




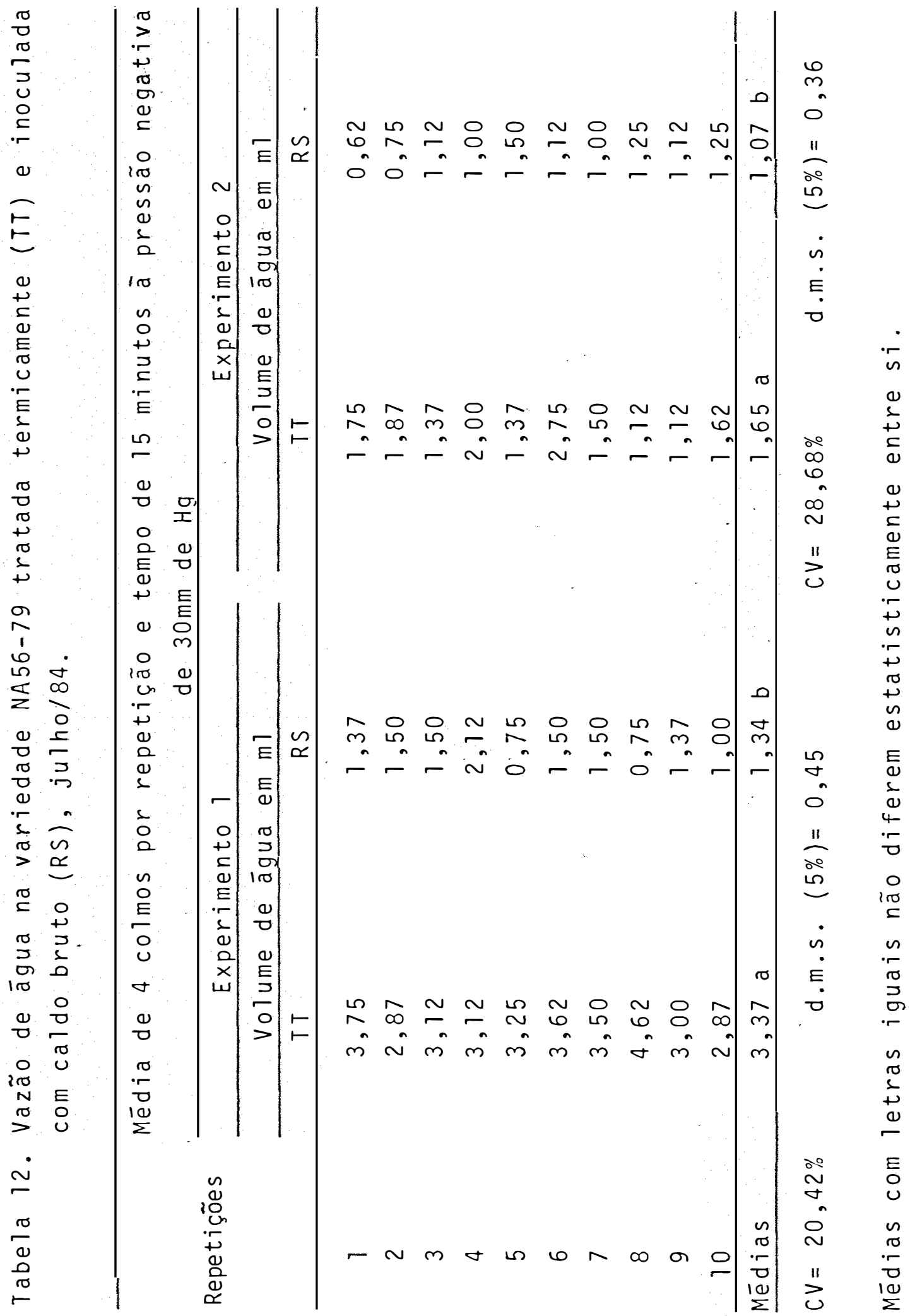


4.4.2. Determinação da Percentagem Média de Vasos Colo ridos pelo Método de Vazão de Soloção Corante.

As notas médias e respectivas percentagens de vasos coloridos nas variedades CB41-76 e NA56-79, são apresentados nas Tabelas 13 e 14 , respectivamente.

A anālise de variāncia acusou valores de F signi ficativos, ao nivel de $1 \%$ de probabilidade, para os resultados do experimento 2 e ao nivel de 5\% de probabilidade, para os re sultados do experimento 1 da Tabela 13. Porém, para os resulta dos dos experimentos 1 e 2 da Tabela 14, a anālise de variānci a mostrou $F$ significativo, ao nivel de $1 \%$ de probabilidade. 


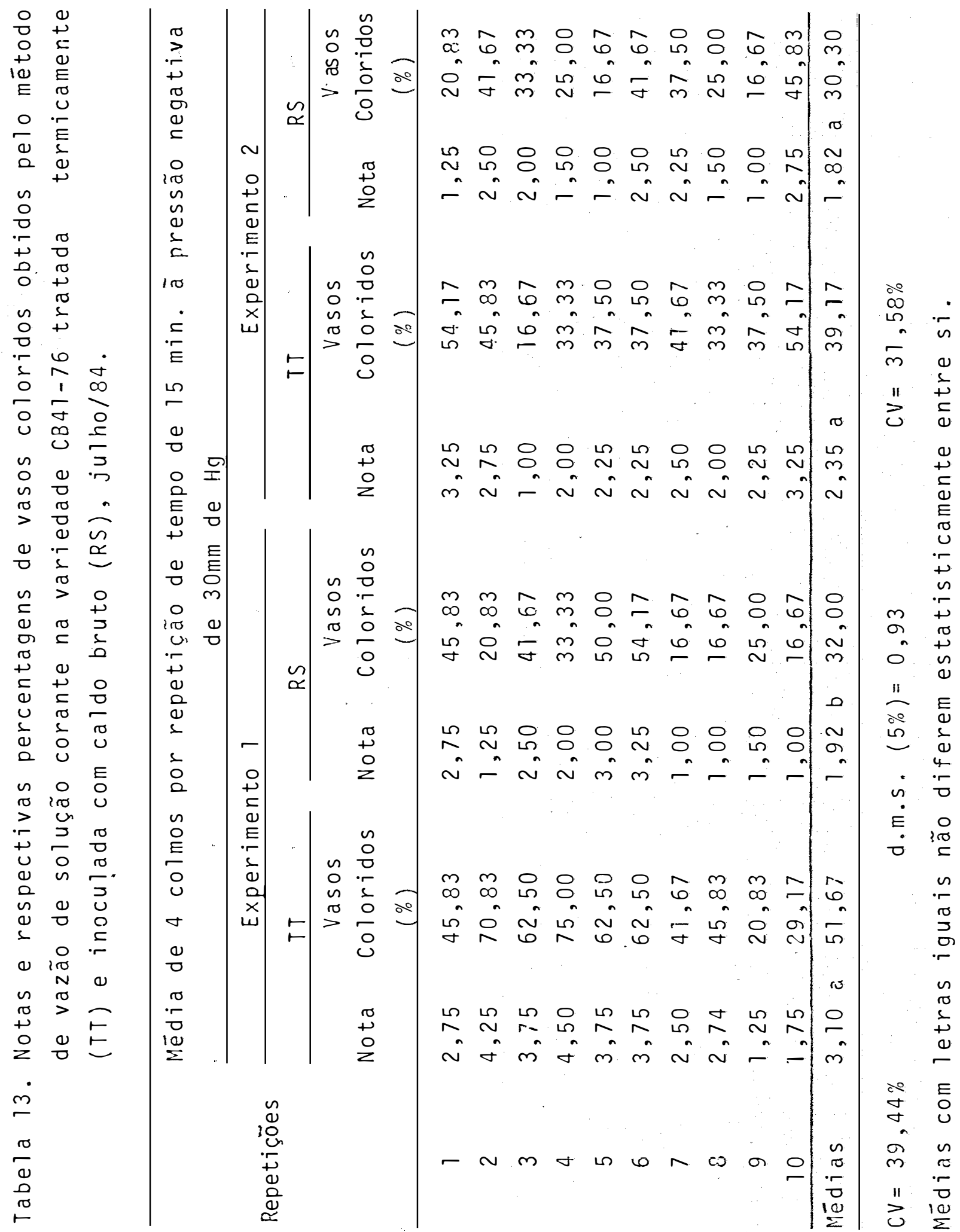




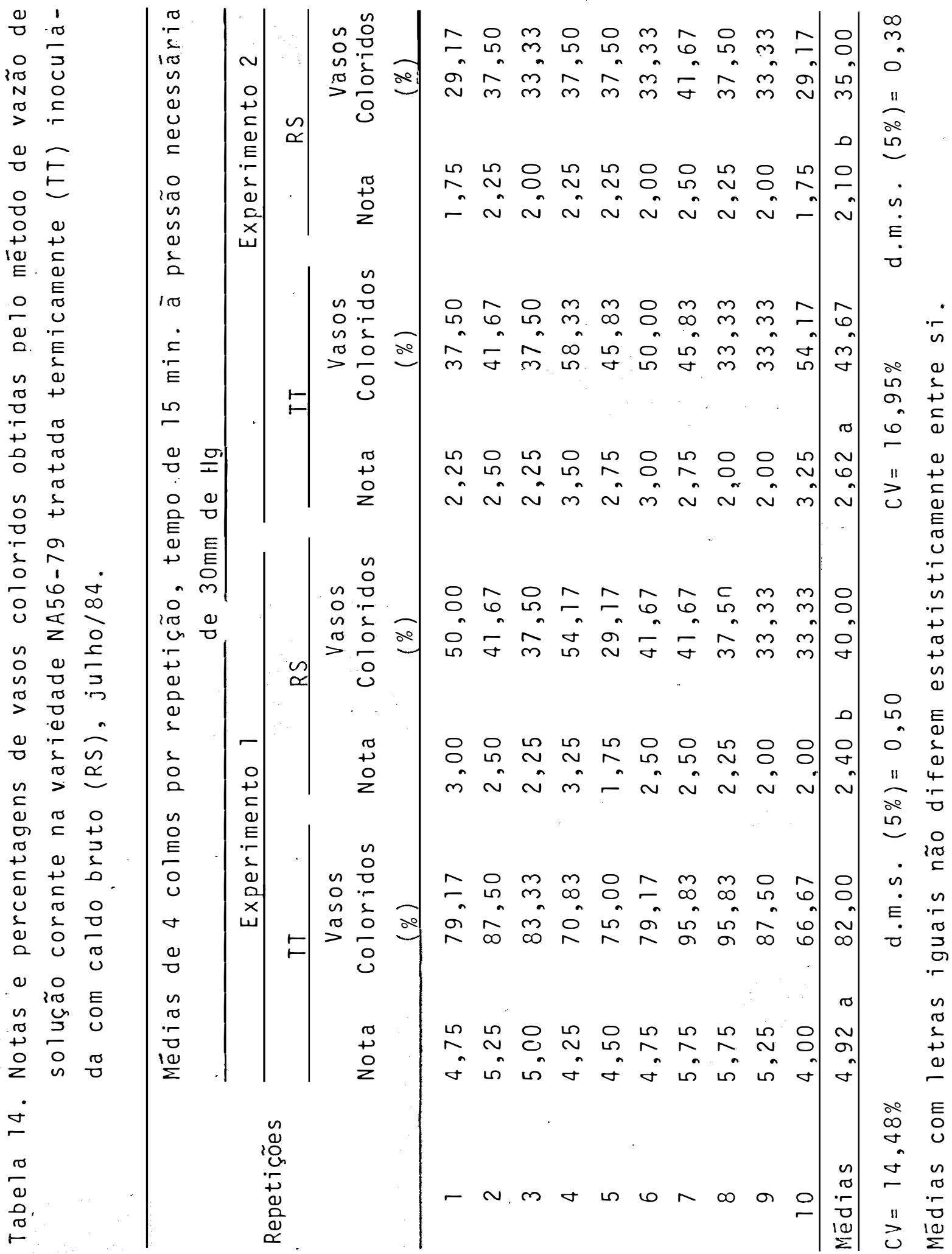


4.4.3. Determinação da Percentagem Média de Vasos Coloridos, pelo Método de Coloração do Xilema pelo Fluxo. Transpiratōrio.

As notas e respectivas percentagens de vasos coloridos nas variedades CB41-76 e NA56-79, são apresentados nas Tabelas 15 e 16 , respectivamente.

As anālises de variāncia acusaram diferenças sig nificativas ao nivel de $1 \%$ de probabilidade, pelo teste F, Dara os resultados encontrados nas Tabelas 15 e 16 .

4.4.4. Comparação entre os Métodos: de Vazão de Solução Corante e do Fluxo Transpiratório, na Determinação de Sanidade de Colmos Sadios (TT) e Doentes (RS).

As notas e respectivas percentagens de vasos coloridos nas variedades CB41-76 e NA56-79, para os dois métodos, encontram-se nas Tabelas 17 e 18,19 e 20 , respectivamente.

As anālises de variāncia acusaram diferenças de F significativas, para métodos, sanidade e interação entre eles, para os resultados das Tabelas 17,18 e 19.

Porém não acusaram diferenças significativas ao nível de $5 \%$ de probabilidade, para a interação entre método e sanidade nos resultados da Tabela 20. 


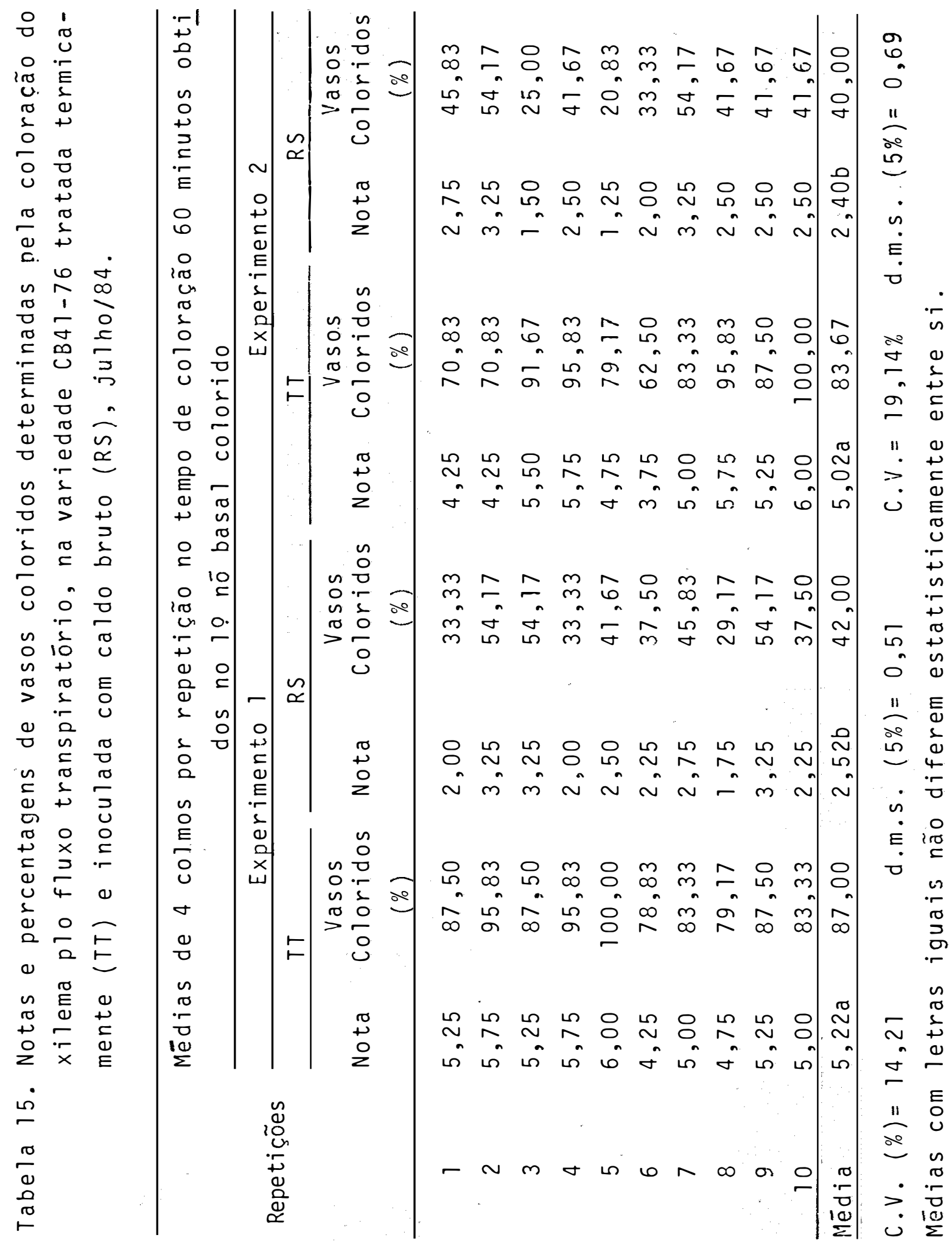




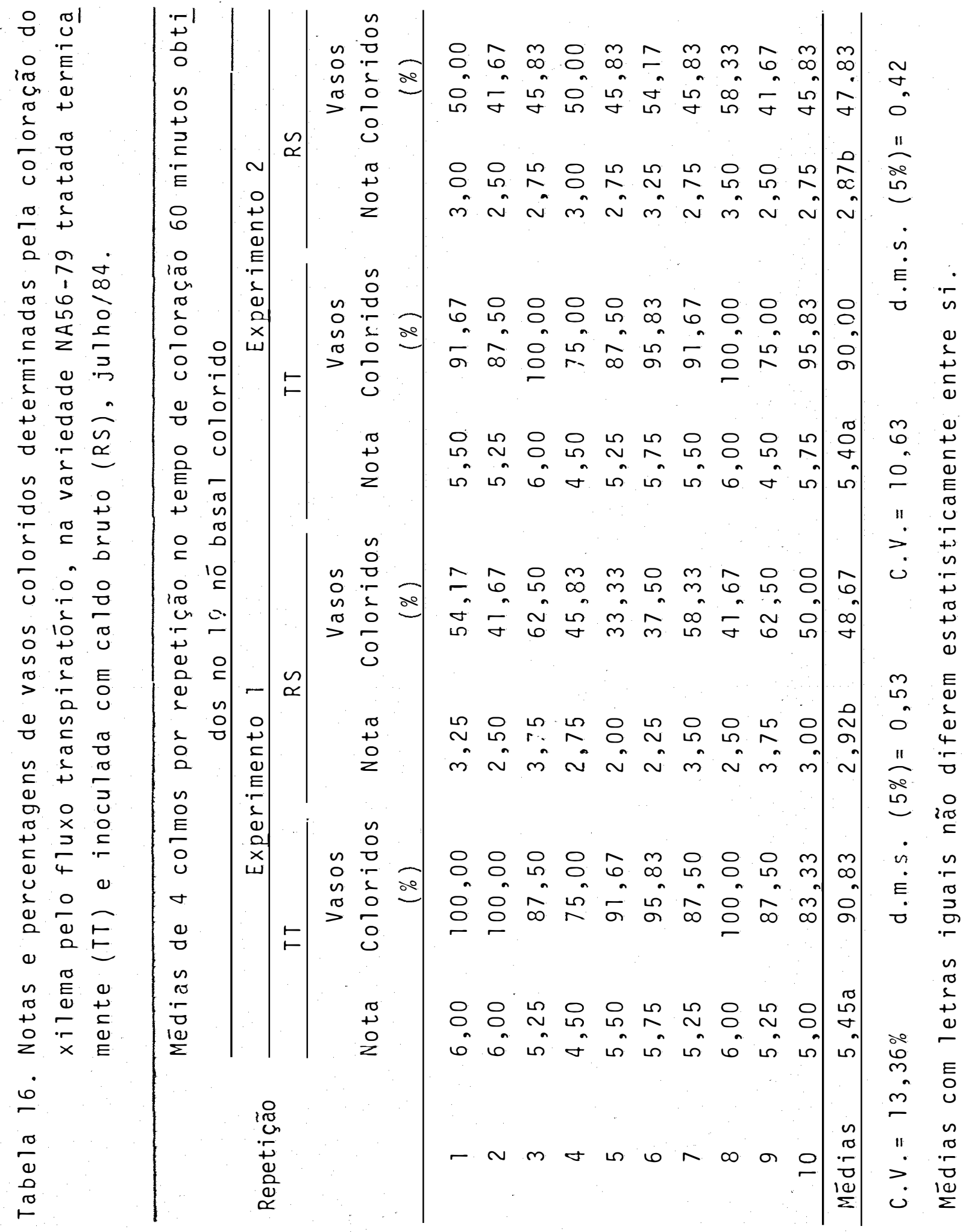




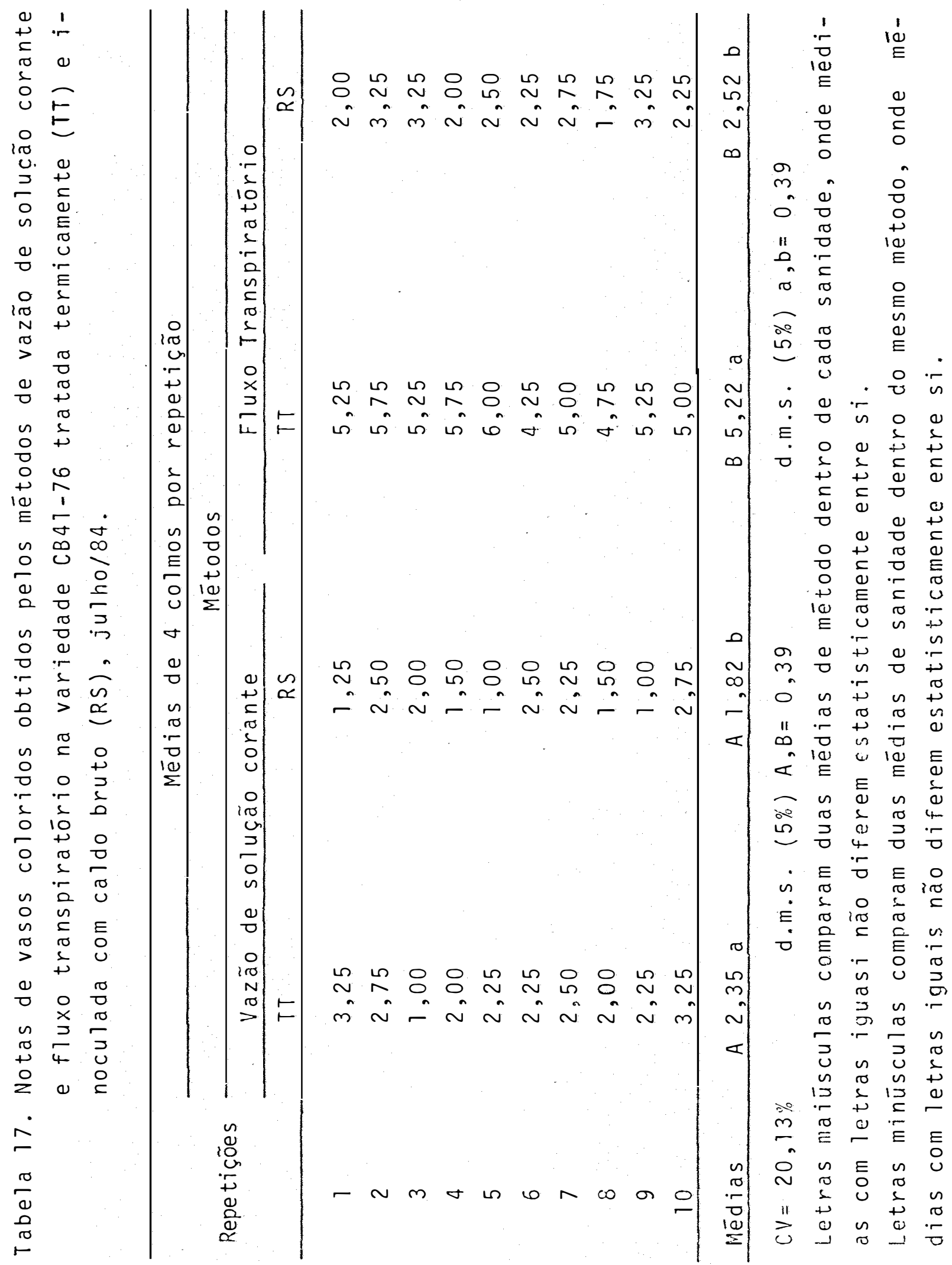




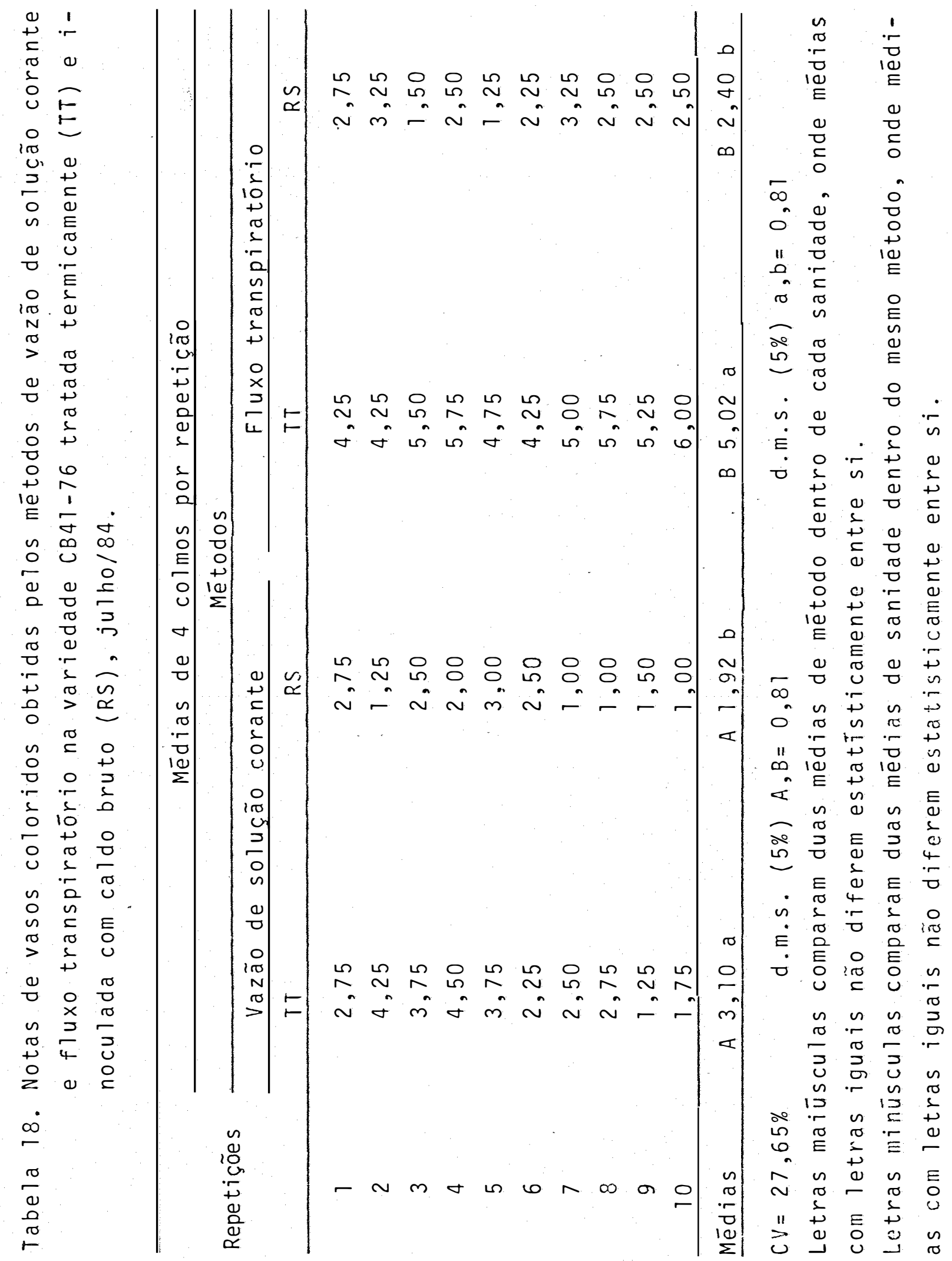




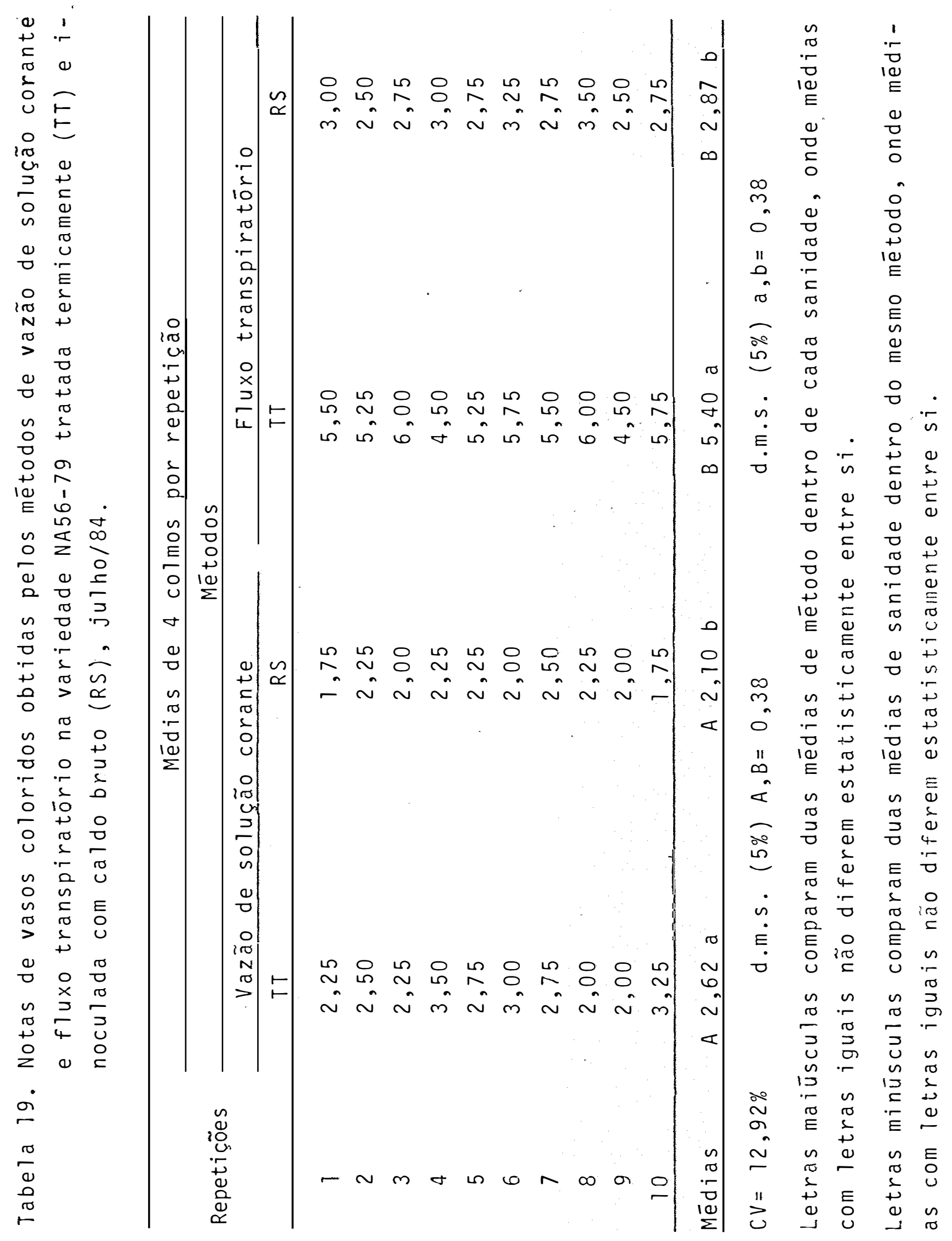




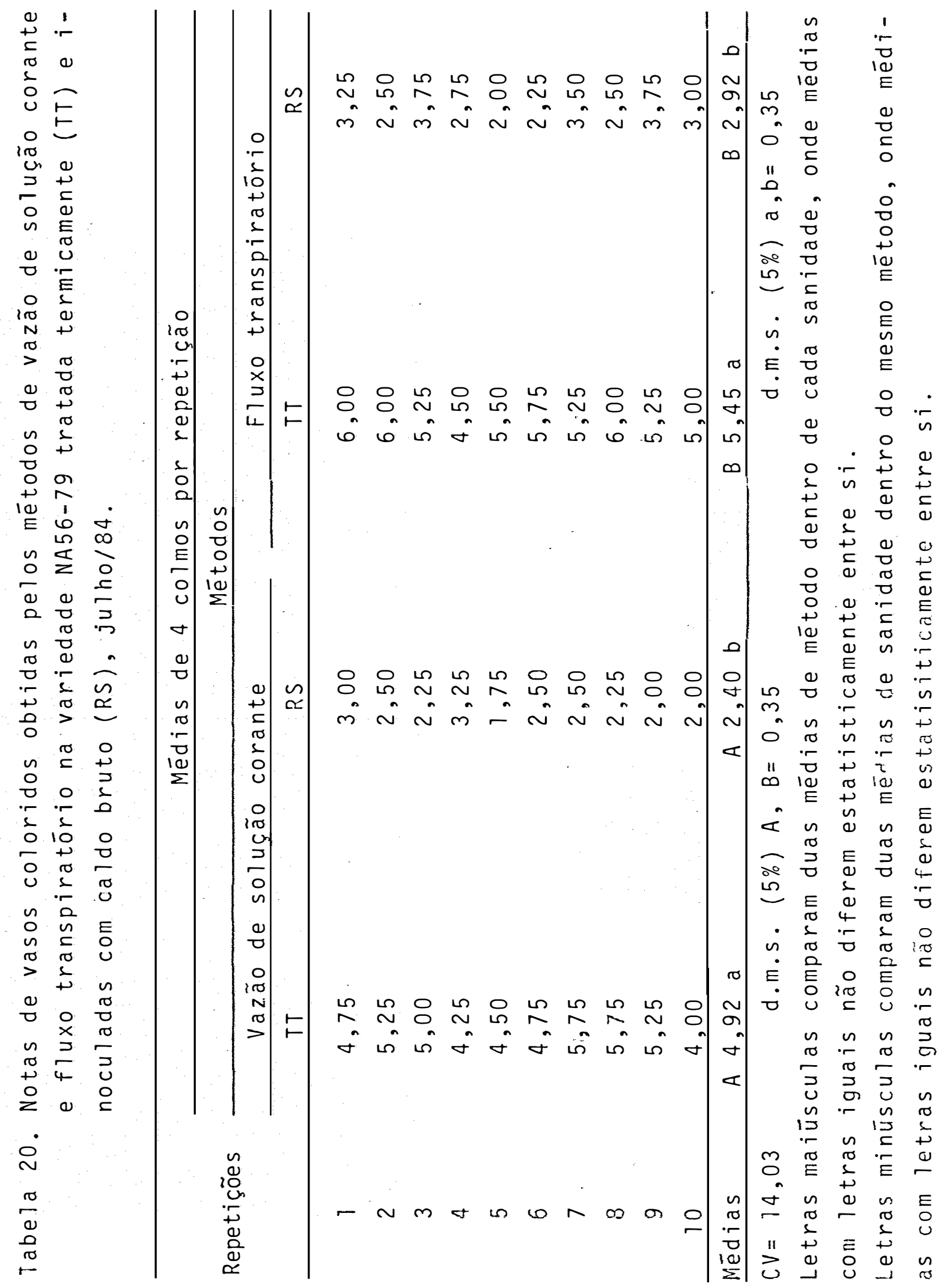


4.5. Aplicação do Mētodo de Coloração do Xilema pelo fluxo Transpiratório, no Controle de Qualidade de Viveiros e Canaviviais Comerciais de Cana-de-Açūcar.

Os resultados médios de contaminação do RS, refé rentes as amostragens no item 3.6., são apresentados nas Figuras 13,14 e 15 , respectivamente.

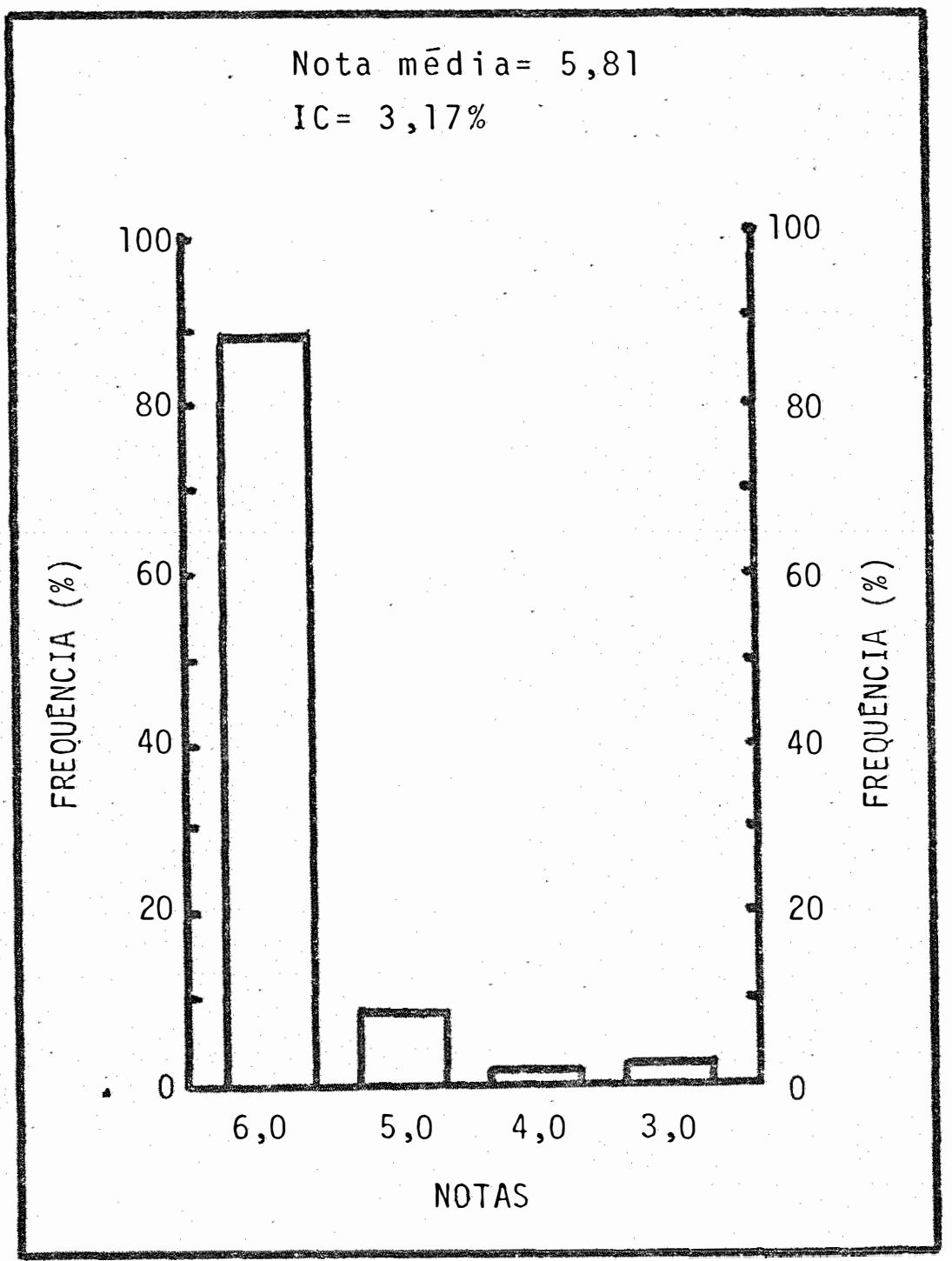

Figura 13. Indice de contaminação (IC) em viveiro secundārio de IAC52-150, 79 colmos tes tados, outubro/84. 


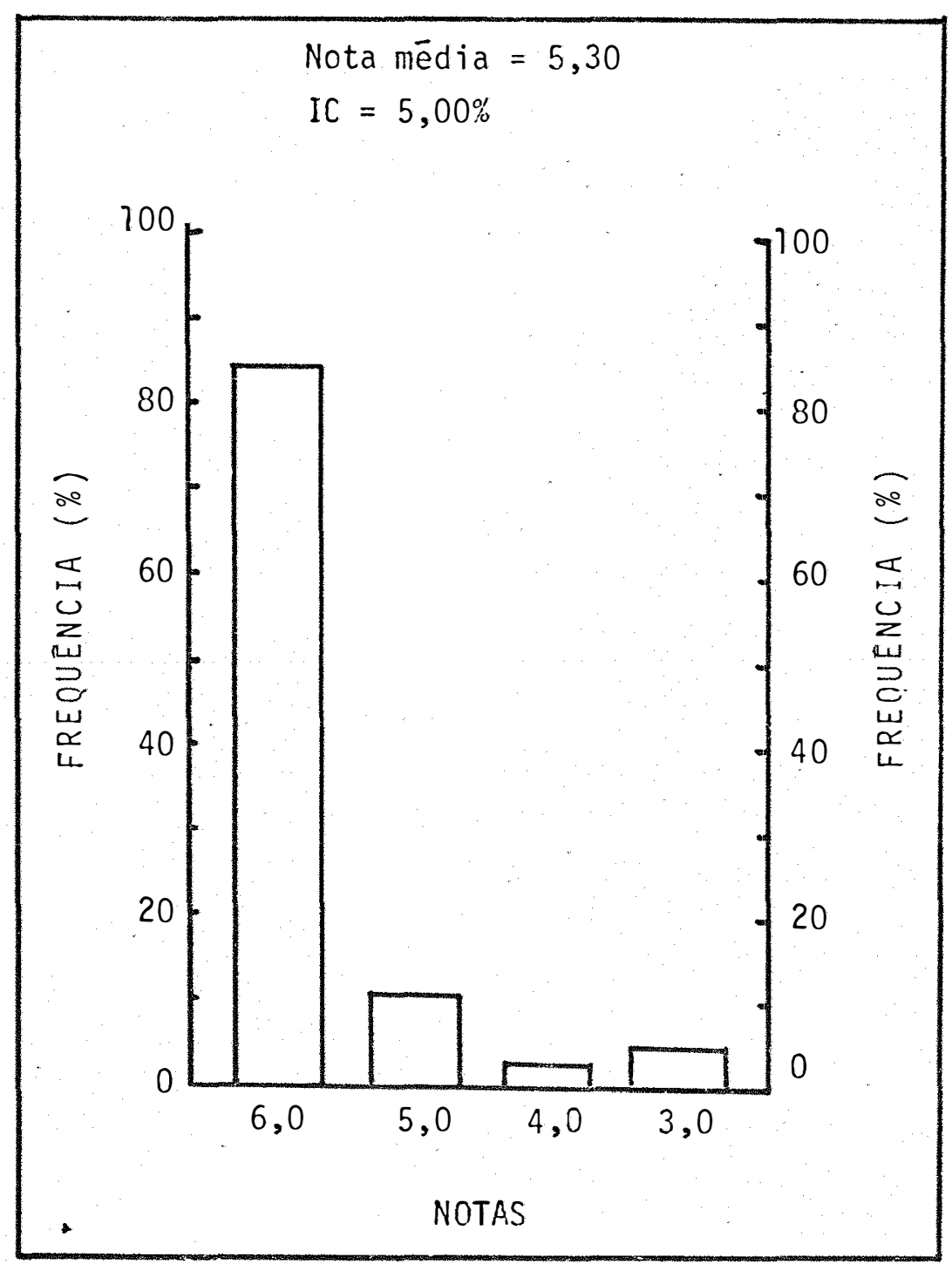

Figura 14. Indice de contaminação (IC) em viveiro secundārio de NA56-79, 80 colmos testa dos, outubro/84. 


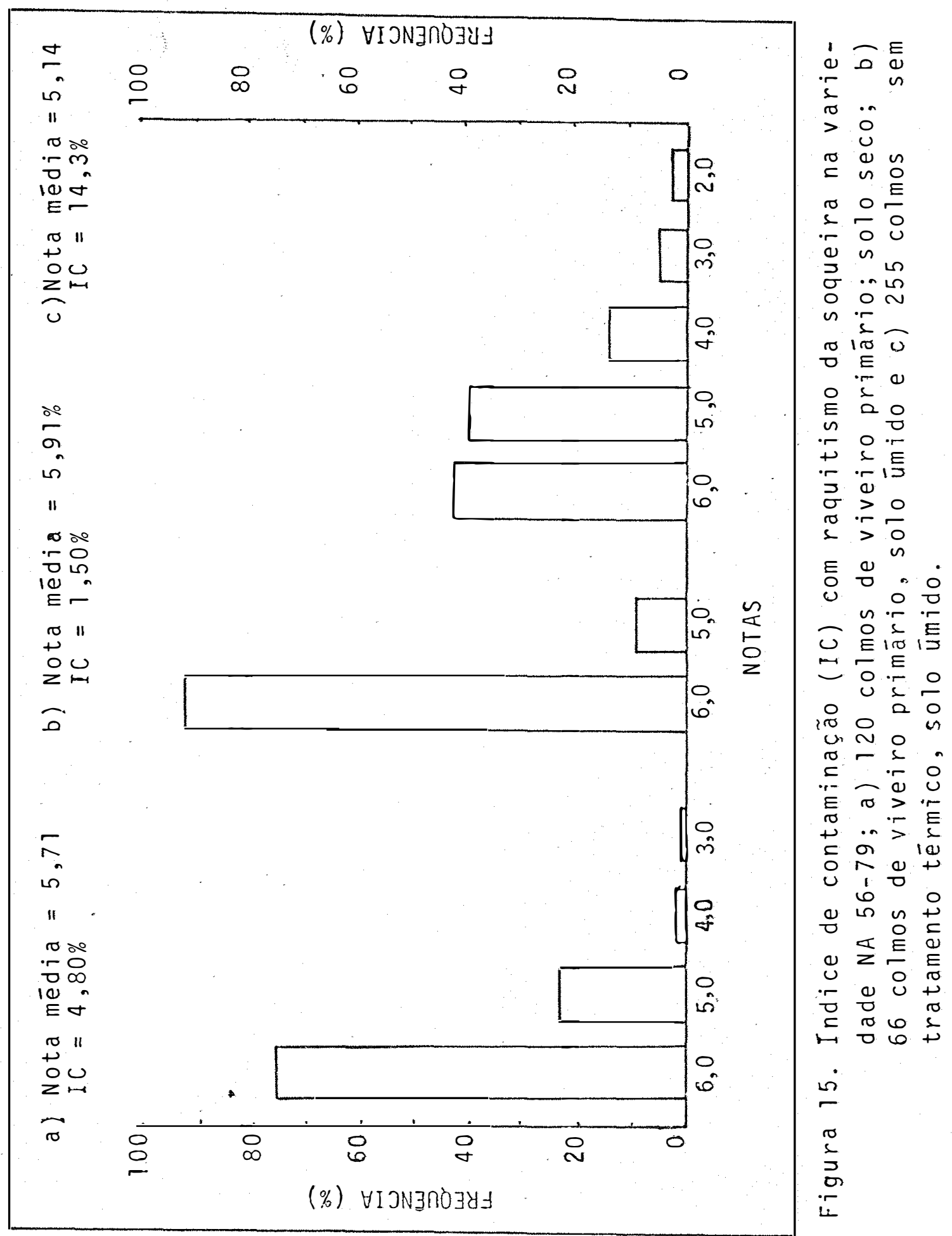




\section{DISCUSSAOO}

No presente trabalho as comparações foram sempre efetuadas dentro de uma mesma :ariedade, comparando-se colmos de viveiros tratados termicamente (TT) e colmos de viveiros inoculados com caldo bruto (RS), ou na determinação do indice de contaminação do RS em viveiros e canaviais comerciais de canade-açūcar, não se preocupando em avaliar o comportamento de va riedades com relação à resistēnci.a ao RS. O objetivo bāsicofoi procurar detectar parāmetros que auxiliem na determinarão do ín dice de contaminação (IC) pelo RS em viveiro e canaviais comer ciais, afim de se evitar a disseminação da doença a partir de material não curado pela termoterapia.

5.1. Padronização dos Sintomas do RS pela Coloração do Xile . ma

Atravēs dos resultados de coloração do xilema exemplificados na Figura 1 , onde uma gama de nós coloridos de diferentes colmos de cana-de-açūcar são apresentados graficamente, verifica-se uma variação de nōs totalmente sadios, ou seja, com 100\% de vasos funcionais coloridos, até totalmente contaminados, isto $\bar{e}$, nenhum ou poucos vasos funcionais colori dos. Estas variações são observadas visualmente pela presença 
no nō de regiões escurecidas compreendendo vasos não coloridos. A estas variações foram atribuídas notas de 1 a 6 , de acordo com a dimensão e nūmero de regiöes escurecidas presentes em cada nō, conforme descrição no item 3.4.2.2.

Ainda, com relação aos resultados da Figura 1, ve rifica-se que nós mais sadios, aqueles com maior percentagem de vasos funcionais coloridos, permitem uma maior vazão do que os nós mais contaminados com menor percentagem de vasos funcionais coloridos. Estes resultados vêm corroborar as conclusões obtidas por CRUz (1983), que afirma ser possível através da colora ção do xilema comprovar de forma direta que o tratamento térmi co $(50,5 \div \mathrm{C} / 2 \mathrm{~h})$, não controla totalmente o RS, conseguindo inclusive determinar o indice de contaminação do viveiro.

os padrões grāficos representando a escala de sin tomas do RS, para avaliação do índice de contaminação (IC) de ví veiros e canaviais comerciais apresentados na fiqura 2 foram e laborados após minuciosas observações dos nōs exemplificados na Figura 1 e, adicionalmente, em aproximadamente 10.000 desenhos de nōs de colmos TT e RS desenhados em plásticos transparentes, conforme descrito em 3.4.2.1.

5.2. Tempo Mínimo Necessārio para a Coloração do Xilema, pe 10 Método de Vazão de Solução Corante

A anālise de variància das notas dos sintomas, mos. trados na Tabela 1, não acusou diferenças significativas para os tempos usados para a coloração do xillema. Porém, estas dife renças foram altamente significativas quando se comparou material TT e RS. Os dados evidenciaram ser possivel quantificar os sintomas com a utilização do fluxōmetro e detectar falhas do tratamento térmico no controle do RS quantificando, assim, a contaminação do viveiro. Um tempo mínimo de 2 minutos é sufici ente para a coloração do xilema. Entretanto, como os resulta dos foram obtidos sem o controle de outros fatores que interfe 
rem na coloração do xilema, maiores estudos necessitam serem re alizados para a sua confirmação.

5.3. Fatores que Interferem no Método de Coloraçäo do Xilema pelo Fluxo Transpiratório.

5.3.1. Altura de Recorte do Colmo

Comparando-se as percentagens médias de vasos co loridos em cada nó e o nūmero médio de nós coloridos nos col mos TT cortados no 2 e e 4 o nó (Fig. 3) verifica-se o maior nūmero de nós e vasos coloridos, naqueles cortados no 40 nó. Evi denciando que houve interferéncia da altura de recorte do colmo, na coloração do xilema pelo método do fluxo transpiratório e que o corte no 40 nó é melhor que o corte no 20 nó.

Resultados semelhantes foram obtidos quando se comparou a percentagem média de vasos e nūmero de nós coloridos de colmos com RS, cortados no 20 e 49 nó.

Ainda com relação à Figura 3 , quando se comparou separadamente colmos TT e RS, recortados no 20 e 40 nó, observou-se que a diferença entre a percentagem média de vasos colo ridos dos colmos recortados no 40 nó foi maior do que a diferença encontrada entre os colmos no 29 nó.

os resultados da anālise de variāncia dos dados apresentados na Tabela 2, indicaram haver diferenças sianifica tivas para colmos tratados termicamente, recortados no 20 e 40 nō, diferenças significativas também foram alcançadas quando se comparou colmos TT e RS, recortados 2? e 4 o.

\subsubsection{Hora de Corte da Muda}

Os resultados da Figura 4 mostraram que houve di ferenças significativas entre a percentagem média de vasos co- 
loridos para colmos cortados às 8:00 horas, em relação aos col mos cortados nos demais horários. observa-se ainda que a diminuição da diferença de percentagem média de vasos coloridos em cada nó, para os colmos cortados às 11:00: 13:30 e 15:30 horas, se deu principalmente devido à diminuição de coloração nos col mos TT, evidenciando que a hora de corte da muda interfiriu no fluxo transpiratōrio. Com relação a colmos com RS, as percenta gens de vasos coloridos foram praticamente iquais, exceto para os colmos cortados às 15:30 horas, que apresentaram uma percen tagem média de vasos coloridos inferior aos demais horários.

os resultados da Tabela 3 confirmaram a interferéncia da hora de corte da muda no fluxo transpiratório, indicando haver diferenças significativas, tanto dentro de sanidade, quanto entre sanidade. Demonstram, ainda, que a nota média obtida nos colmos TT cortados às 8:00 horas foi superior às mé dias obtidas nos colmos cortados nos demais horários, evidenci ando, para as condiçoes do experimento, que colmos TT cortados às 8:00 horas sofreram menos interferéncia do que os colmos cortados nos demais horários.

Na literatura consultada não foi encontrida nenhuma referéncia de que a hora de corte da muda interfere na coloração do xilema pelo fluxo transpiratōrio. Porém, resultados semelhantes foram citados por ALEXANDER (1973) sobre a variação fotossintética com relação à intensidade de luz, em experimento de cana-de-açūcar em solo de baixa umidade, porém, a atividade fotossintética mostrou-se constante por todo o dia,. quando o solo se apresentava na capacidade de campo. SUTCLIfFE (1980) revela que a maioria das flantas está sujeita a uma deficiência de āgua durante o dia, seguida de uma recuperação a noite.

\subsubsection{Tempo de Cavitação}

Os resultados apresentados na Figura 5 mostram 
que a partir do tempo de 30 segundos houve alteração no fluxo transpiratōrio, confirmando a hipótese de que o tempo de cavitação interfere no mētodo de coloração do xilema.

Confirmam o exposto acima, os resultados da Tabe la 4 que mostrou diferenças significativas entre o tempo de 0 5 segundos e os demais tempos de cavitação. Essas diferenças são melhor evidenciadas quando se compara os resultados da Figura 6 , onde a diferença da percentagem média de vasos coloridos en tre colmos TT e RS foi maior no tempo de 0-5 segundos. Com o tempo de cavitação de 30 segundos esta diferença diminui para praticamente se anular com o tempo de cavitação de 60 segundos. observa-se ainda, que o efeito de cavitação foi mais acentuado em colmos TT do que em colmos RS, evidenciando, mais ainda, a interferēncia do tempo de cavitação na coloração do xilema pe 10 fluxo transpiratōrio. Corroborou essas observações a anāi ise de variáncia dos dados (Tabela 5) os quais acusaram haver di ferenças significativas para tempo de cavitação, para sanidade e para interação entre eles.

\subsubsection{Corantes}

Os resultados apresentados na Figura 7 mostraram que a safranina 0 , coloriu maior percentagem de vasos e nós, se guida pelo vermelho $\mathrm{C} 2$ e, por fim, com média bem inferior coloca-se a anilina vermelho 145. Dos corantes testados no desen. volvimento do trabalho apenas aqueles apresentados na Figura 7 , originaram resultados que merecem discussão.

Entretanto, quando se estudou os três corantes em colmos TT e RS conforme os ilustrados na Figura 8 , o corante $\underline{a}$ nilina vermelho 145 apresentou maior percentagem de vasos colo ridos, para os primeiros nōs de colmos TT e, também, maior diferença de vasos coloridos entre colmos TT e RS. Porém, essa di ferença diminuiu drasticamente nos nōs subsequentes, tanto para anilina vermelho 145 quanto para o vermelho $c 2$, não aconte 
cendo o mesmo com a safranina 0 , que se manteve mais constante. Esses resultados, submetidos à anālise de variāncia (Tabela 6) acusaram diferenças significantes para corantes. No entanto,o teste de Tukey demonstrou que esta diferença ocorreu entre a nilina vermelho 145 e os demais corantes, mas não entre safranina 0 e o vermelho C 2 .

Apesar da anālise estatistica não ter acusado di ferenças significativas entre os 2 corantes, com relação a per centagem de vasos coloridos, pode-se tecer alguns comentārios sobre a eficiência de cada corante. O corante anilina vermelho 145, como visto nas Figuras 7 e 8 , apresentou inconsistência, ora commaior, ora com menor percentagem de vasos coloridos, po rém, quando coloridos, os vasos foram facilmente distinguidos dos demais tecidos no nō. O corante vermelho $\mathrm{C} 2$, apesar de apresentar-se constante nos dois experimentos estudados, conseguindo inclusive o mesmo percentual médio de $86,67 \%$ de vasos coloridos nas duas condições, mostrou-se imprōprio por se difundir pelos tecidos adjacentes aos feixes vasculares, tornando di fícil a distinção dos vasos coloridos dos demais tecidos do nó. A safranina 0 foi o único produto que se manteve estávê nos testes, não colorindo tecidos fora dos feixes vasculares.

os resultados apresentados nas Figuras 9 e 10 , e videnciam ainda mais a inconsistência da anilina vermelho 145 com relação à safranina 0 . Enquanto com a safranina 0 se obteve os îndices de contaminação de 12,20 e $50 \%$, com a anilina ver melho 145 obteve-se 40,56 e $70 \%$, respectivamente. Esta instabilidade no comportamento da anilina vermelho 145 , torna o uso do produto inviável. No entanto, maiores estudos devem ser rea lizados com a anilina vermelho 145 por ser um produto barato e de fācil aquisição, o que tornaria o método ainda mais viāvel.

\subsubsection{Tempo de Coloração do Xilema}


sentados na Figura 11, verificou-se que apenas o tempo de 15 mi nutos demonstrou ser insuficiente para a translocação do coran te através do xilema, apresentando um menor nümero de nós e vasos coloridos em relação aos tempos de 30,45 e 60 minutos, que se mostraram igualmente suficiente na coloração do xilema. Com relação a colmos RS, verificou-se o mesmo fato ocorrido paracol mos TT. No entanto, quando se comparou os resultados de colmos TT e RS, observou-se diferenças significativas para todos os tempos de coloração.

Evidenciando ainda mais a interferência do tempo de coloração na translocação do corante através do xilema, os resultados das Tabelas 8 e 9 , apresentaram para colmos TT valo res de F, significativas ao nível de $1 \%$ e 5\% de probabilidade, para tempo de coloração. No entanto, atravēs do teste de Tukey (5\%) apenas o tempo de 15 minutos diferiu estatisticamente dos demais tempos de coloração, que não diferiram entre si. Do mes mo modo, quando se comparou os resultados de colmos TT e RS da Tabela 9 , as diferenças foram altamente significativas, inclusive para o tempo de coloração de 15 minutos.

\subsubsection{Ataque de Broca (Diatraea spp)}

A broca (Diatiaea sppl interfiriu no método de co löração do xilema pela corrente transpiratōria, como ficou demonstrada na Figura 12, onde colmos livres de broca apresentaram maior nümero de vasos funcionais do que colmos brocados. No en tanto, esta interferência só foi verificada em colmos onde havia perfuração da broca na região do 4 ọ nō ou no internōdio imediato acima do internōdio avaliado. Não se observou interferência quando estas perfurações se deram nos internōdios más afastados do 49 nō. Estes resultados foram confirmados pela anālise de variāncia da Tabela 10 , que acusou $F$ siginificativo, ao nivel de $1 \%$ de probabilidade.

Resultados semelhantes foram encontrados por BULL, 
et alij. (1972) trabalhando com colmo de cana-de-açūcar, onde fizeram corte rompendo o xilema em diferentes posições e fazen do passar solução corante (eosina). POSTLEWAITE e ROGRS (1958) injetando isōtopo $\mathrm{p}^{32}$ no xilema de pinheiro, observaram que o isótopo $\mathrm{p}^{32}$ movia-se lateralmente quando eram feitos cortes pro fundos no tronco, logo acima do ponto de injeção. SUTCLIFFE (1980) demonstrou que o suprimento de āgua para as partes superiores em ārvores não foi necessariamente paralisado, mesmo com cortes sobrepostos. Estes dados mostram a eficiēncia da difusão da ăgua de feixes vasculares obstruídos para outros feixes sadios.

\subsubsection{Umidade do Solo}

Embora, o presente estudo não tenha sido dirigido, com o intuito de se avaliar o efeito da umidade do solo, in terferindo no método de coloração do xilema pela corrente trans piratōria, foi possivel pelos resultados obtidos e literaturas consultadas, observações que a colocaram como um fator de extrema importáncia na. precisão dos resultados.

Os trabalhos de LOUSTALOT (1945) demonstraram que folhas de pecan mostraram respiração e fotossintese subnormal quando a umidade do solo estava muito baixa ou muito alta, relacionando o grau dedeclínio de fotossíntese e a falta de āgua, com a queda na taxa de respiração e fotossintese. ASHTON (1956) estudando o efeito da umidade do solo na fotossíntese da canade-açūcar, constatou que a fotossintese era máximá na capacida de de campo do solo e mínima no ponto de murchamento permanente. SUTCLIFFE (1980) mencionou que o movimento de àgua no xile ma se dá em resposta ao potencial de água entre as superfície transpirante e a solução do solo, causada principalmente pelá trans piração e que esse movimento diminui com a queda do potencial de āgua do solo, ocorrendo o fechamento dos estōmatos e cessan do as atividades de fotossintese.

VALARINI (1978) e DOUGLAS (1981) observaram au- 
mento da vazão de āgua em secções de colmos de cana-de-açūcar, após ter chovido, independentemente de tratamento e época da determinação da vazão.

No presente trabalho, pelos dados colhidos em ju 1ho de 1984. (Tabela 11 e 12), més este que foi precedido por um longo período de estiagem como pode ser observado nos dados me tereológicos apresentados no anexo 8 verificou-se que houve uma vazão bastante inferior quando comparadas às encontradas por VALARINI (1978), DOUGLAS (1981) e CRUZ (1983), em período normal de chuva. Resultados semelhantes foram encontrados quando se comparou as percentagens médias de vasos coloridos obtidas em julho de 1984, com as percentagens de vasos coloridos obtidos em setembro. Como a metodologia e o material testado foram os mesmos, os resultados podem ser atribuidos em grande parte a umidade do solo diferentes nas duas determinações.

5.4. Avaliação da Eficiência dos Três Métodos na Determináção de Sanidade de Colmos Tratados Termicamente (TT) e Inoculados com Caldo Bruto (RS)

\subsubsection{Método de Vazão de Āgua}

De acordo com os resultados (Tabelas 11 e 12), ob serva-se que a vazão média dos colmos TT foi sempre maior que em colmos RS, confirmando resultados obtidos por VALARINI (1978), DOUGLAS (1981) e CRUZ (1983), embora, a vazão média ora em discussão fosse inferior àquelas encontradas pelos autores citados.

0 mētodo de vazão de àgua com auxîlio de fluxōme tro determinou diferenças significativas entre a vazão média em colmos TT e RS, mas não se mostrou suficientemente eficiente e eficaz para quantificar sintomas do RS em colmos de cana-de-açūcar. Os resultados encontrados por VALARINI (1978), DOUGLAS (1981) e CRUZ (1983), demonstraram existir grandes variações na 
vazão mēdia, tanto em colmos TT quanto em colmos RS, ficando, deste modo, difícil se precisar o grau de contaminação do mate rial testado, mesmo se comparando material TT e RS. Porém, estes resultados não são suficientes para por em risco a eficien cia do método, na avaliação da resistēncia de variedades ao RS, determinada por VALARINI (1978). DOUGLAS (1981) e CRUZ (1983).

\subsubsection{Método de Vazão de Solução Corante}

Os resultados de vazão das Tabelas 13 e 14 confirmam as observações de VALARINI (1978) e CRUZ (1983), que en contraram correlações positivas entre o número de vasos colori dos e a vazão de àgua em colmos de cana-de-açūcar. Entretanto a baixa percentagem de vasos coloridos apresentados pelos resultados no presente trabalho, evidenciam a imprecisão do méto do na avaliação do índice de contaminação do RS, através da co loração do xillema. Preocupação esta, colocada por VALARINI(1978).

Mesmo tendo os resultados (Tabelas 13 , experimen to 1 e Tabela 14, experimentos 1 e 2) apresentados baixas percentagens de vasos coloridos, determinados através da escala de sintomas, houve diferenças altamente significativas entre colmos TT e RS. Porēm, para os resultados da Tabela 13, experimen to 2 , a anāilise de variāncia não acusou diferenças de F significativas, ao nivel de $5 \%$ de probabilidade, para colmos TT e RS.

Devido as condições de seca em que se encontrava o experimento por ocasião da colheita dos dados e, como jā foi mencionado por muitos trabalhos que a umidade do solo interfere na vazão de āgua no colmo, apenas estes resultados não inva lidam o uso do fluxōmetro na coloração do xilema, para quantificar os sintomas do RS, em viveiros de cana-de-açūcar. Porém de acordo com CRUZ (1983), mais estudos bem como outros métodos devem ser utilizados. 


\subsubsection{Método de Coloração do Xilema pelo Fluxo Trans- piratōrio.}

As tabelas 15 e 16 apresentam as notas médias de terminados pela escala de sintomas e respectivas percentagens de vasos coloridos onde mostram, através das anālises de variância, valores de $F$ altamente significativos, evidenciando diferenças estatisticas entre colmos TT e RS.

Ainda, com relação aos resultados das Tabelas 15 e 16, observa-se que houve regularidade nos resultados, tanto dentro de colmos TT, quanto dentro de collmos RS. Resultados es tes, que comparados com os dos dois métodos anteriormente discutidos, revelam através dos coeficientes de variação, uma maior precisão na determinação de sanidade entre colmos TT e RS.

5.4.4. Comparação entre os Métodos: Vazão de Solução Co rante e do Fluxo Transpiratório na Coloração do xilema.

Observa-se nas Tabelas 17 a 20 , uma maior percen tagem média de vasos coloridos para os colmos TT avaliados pe10 método de coloração do xilema pelo fluxo transpiratōrio, existindo também maior diferenças de percentagens de vasos colo ridos entre colmos TT e RS, em comparação com o método vazão de solução corante. Sendo as mudas utilizadas nos dois métodos oriundas do mesmo experimento, fica evidenciado uma maior efici ència na avaliação de falhas na termoterapia de mudas contra o RS para o método de coloração do xilema pelo fluxo transpirató rio.

5.5. Aplicação do Método de Coloração do Xilema pelo Fluxo Transpiratório, no Controle de Qualidade de Viveiros e Canaviais Comerciais de Cana-de-Açūcar. 
Os resultados (Figuras 13 a 15 ) demonstram ser possivel medir o nível de contaminação de mudas usando-se a es cala de sintomas para o controle da disseminação RS, em viveiros de cana-de-açūcar. Estes resultados confirmam a hipōtese for mulada por CRUZ (1983) de que pela coloração vascular pode de tectar a contaminação de mudas.

Os resultados apresentados (Figuras 13, 14 e 15b) confirmam observações de HUGHES e STEINDL (1955); STEINDL (1961); HUGHES et alii (1964); LOPES-ROSA E ADSUAR (1970), TOKESHI (1978); MATSUOKA (1972, 1983, 1984) e MASUDA (1984); que o tratamento térmico $(50,50 \mathrm{c} / 2$ horas $)$, não assegura cura total do material tratado.

Com relação a Figura $15 a$ e b, os resultados comprovam a interferência exercida pela umidade do solo no movimento de āgua no colmo, visto que material do mesmo viveiro, quando analisado após ter chovido, apresentou menor índice de contaminação do que quando analisado antes da chuva, com o so10 seco.

As percentagens de colmos com diferentes indices de contaminação (Figura 15b e c) determinadas através do método de coloração do xilema pelo fluxo transpiratório evidenciam ainda mais, a eficiência do método no controle da disseminação do RS, dentro de viveiro e canaviais comerciais de cana-de-açu car. Outro argumento essencial que viabiliza a utilização do mé todo, no controle da qualidade de viveiro e canaviais comerciais, está em não ser necessārio a comparação com material comi RS, para se avaliar o estado de sanidade da variedade em questão.

Ante a eficiência e maior precisão apresentado pelo método de coloração do xilema pelo fluxo transpiratório, tudo indica que este método é mais preciso na avaliação de resistência de variedades ao RS que os métodos de vazão de ãgua e microparcelas descritos por VALARINI e TOKESHI (1980) e MATSUOKA (1980). 


\section{CONCLUSÖES}

Dos resultados obtidos nas condições do presente trabalho, as seguintes conclusões podem ser inferidas:

a) 0 método de coloração do xilema pelo fluxo transpiratório, mostra ser eficiente no controle de qualidade de viveiros de cana-de-açūcar, permitindo quantificar a contaminação do RS em viveiros e canaviais comerciais.

b) 0 método de coloração do xilema pelo. fluxo transpiratório, mostra ser mais preciso do que o de vazão de ā gua e vazão de solução corante, na determinação de diferenças entre colmos sadios e com raquitismo da soqueira.

c) Existe correlação positiva entre a vasão de á gua e a percentagem de vasos coloridos em colmos tratados ter micamente (TT) e inoculados (RS).

d) Os fatores altura de recorte do colmo, hora de corte do colmo, tempos de cavitação, corantes, tempo de colora ção, ataque de brocas e umidade do solo interferem na precisão do método de coloração.

e) A associação do método proposto com as técnicas 
de isolamento da bactēria causadora do RS permitirá detectar a presença deste organismo en plantações com baixos nîveis de contaminação.

f) Com a aplicação do método proposto os custos de controle de qualidade de viveiros serão mínimos e aplicáveis em paises com baixo nível tecnológico.

g) A precisão do método desenvolvido permite pre ver a sua aplicação na seleção de variedades resistentes ao RS, com indices de eficiência e eficācia mạior que o de vazão de á gua.

h) Com o uso do método proposto não serā necessā rio a comparação entre material sadio (TT) e material doente (RS), para se avaliar a sanidade de viveiros.

i) Através da coloração do xilema, foi elaborada uma escala de sintomas do RS, conforme Figura. 2. 
7. LITERATURA CITADA

ADSUAR, J., 1962. Failure rates to transmit the causal agent of the sugarcane ratoon stunting disease. Journal of Agriculture of University of Puerto Rico. Rio Piedras, 46:239240.

ADSUAR, J. e J.H. LOPEZ-ROSA, 1962. Failure to transmit the causal agent of ratoon stunting disease of sugarcane through the soil. Journal of Agriculture of University of FuertoRi co. Rio Piedras, 46:87-90.

ANTOINE, R., 1957. A histo-chemical test for diagnosing ratoon stunting disease of sugarcane. In: 3 Congrës de la P.I.O.S .A., Tananarine, p. 155-160.

ASHTON, F.M., 1956. Effects of a series of cycles of alternating low and high soil water contents on the rate of apparente photosynthesis in sugarcane. Plant Physiology. Rockvilles, $37: 266-273$.

BAILEY, R.A., 1976. Some observations on the bacterium associ ated with ratoon stunting disease of sugarcane. In: Proceedings of the 50 annual Congress - South African Sugar Technologists'Association - Durban, p.60-64. 
BAILEY, R.A., 1977. The systemic distribution and relative occorrence of bacteria in sugarcane varieties affected by ratoon stunting disease. In: Proceedings of the 51. Annual Congress - South African Sugar Technologists' Association, Durban, p.55-56.

BECHET, G.R., 1976. Ratoon stunting disease and rapid diagnostic techniques. In: Proceedings of the 50 Annual Congress - South African Sugar Technologists'Association, Durban, 4p. (paper).

BENDA, G.T.A. 1971. Wilting and death in the ratoon stunting of sudanglass hybrid uprighets. In: AMER. SOU. SUGAR CANE TECHNOL. Proceedings. p.39-47.

BERTELLI, L.G., 1985. Perspectivas do proālcool. São Paulo. 16p. (Palestra proferida no IAA/PLANALSUCAR. SUPER, Piracicaba, em 08/03/85).

BETTI, J.A., A.S. COSTA, 0. PARADELA FILHO, J. SOAVE E S. MATSUOKA 1980. Descoloração vascular na região dos nōs em capim-elefante causada por vārias espécies de bactérias. Fitopatologia Brasilia, 5:139-147.

BOURNE, B.A., 1965. The failure of a species of rabbit to transmit the ratoon stunting virus of sugarcane. In: Proce edings of the XII Congress Internationa? society of sugar. Cane Technologists', Rëduit, p.1071-1077.

CARVALHO, P.C.T., 1963. As viroses da cana-de-açūcar. In: ESALQ/Departamente de Fitopatologia e Entomologia, Piracica ba. Pragas e Doenças da Cana-de-Açūcar. Piracicaba, p.7590 .

CHEN, C.T., S.M. LEE e M.J. CHEN, 1975. Small coryneform bac teria in ratoon stunted sugarcane. Sugarcane pathologists' 
Newsletter. Sydney, $(13 / 14): 6-8$.

CHEN, C.T., M.J. CHEN, e S.M. LEE, 1978. Studies on sugarcane ra toon stunting disease in Taiwan. I Phase - Contrast and electron microscopy of the small coryneform bacteria in the diseaded sugarcane. Report or the Taiwan Sugar Research Institute. Taiwan, 80: 13-20.

CHESTER, K.S., 1959. How sick is the plant? In: HORSFALL J. C. e A.E. DIMOND. Plant Pathology; an advanced treatise. New York, Academic Press, V.1: p.99-142.

CHU, H.T., K.C. LING e S.M. LEE, 1959. Ratoon stunting disease control in Taiwan. In: Proceedings of the $X$ Congress In ternational Society of Sugar Cane Technologists', Honolulu, p:1072-1077.

COLLINS, M.D. e D. JONES, 1980. Lipides in the classification and identification of coryneform bacteria containing peptiloglycans base on 2 . 4 - diaminobutiric acid. Journal of Applied Bacteriology 48: 459-470.

COLLINS, M.D., D. JONES e R.M. KROPENSTEDT, 1981. Reclassifica tion of Corynebacterium ilicis (Marchel Guba and Litsky) in the genus Arthrobacter, as Arthrobacter ilicis comb. Nov Zen tralbl. Backteriol. Para siterited. Infektionskr. Hzg Abst Orig. Reitr. C. 2: 318-323.

COLLINS, M.D., 1983. Cell mall peptidoglycan and lipid composition of the phytopathogen Corynebacterium' rathayi (Smith). syst. Appl. Microbiol. 4: 193-198.

CRUZ, M.M., 1983. Avaliação de Resistência ao raquitismo daso queira pela vazão de āgua em colmos de cana-de-açücar e a in terferéncia da escaldadura das folhas no método. Piracica.ba ESALQ/USP, 51p (Dissertação de Mestrado). 
CRUZ, M.M.; BRILHO, F.F.C.; TOKESHI, H. 1985. Principais doenças da cana-de-açūcar no Estado de Alagoas. Agroquímica CIBA GEIGY, $(25): 128$.

DAMANN JR., K.E. e K.S. DERRICH, 1976. Bacterium associated with ratoon stunting disease in Louisiana. Sugarcane Patho logists' Newsletter. Aiea, (15/16): 20-22.

DAMANN, JR., K.E., K.S. DERRICH, A.G. GILLASPIE JR., B.F. FONTENOT e J. KAO, 1977. Detection of the RSD-Associated bacterium by sereologically specific electron microscopy. In: Proceedings of the XVIII Congress - International Society of Sugar Cane Technologists', São Paulo, p.433-437.

DAMAMM JR., K.E. e G.T.A. BENDA, 1983. Evaluation of commerci al heat - treatment methods for control of ratoon stunting disease of sugarcane,. Plant Disease. St. Paul, 67:966-967.

DAVIS, M.J., A.G. GILLASPIE, JR., R.W. HARRIS E.R.H. LAWSON, 1990. Ratoon stunting disease of sugarcane; isolation of the causal bacterium. Science. Washington, 210: 1364-1367.

DAVIS, M.J., R.H. LAWSON, A.G. GILLASPIE JR. e R.W. HARRIS, 1983. Properties and relationships of two xylem-limited bacteria and a mycoplasmalike organism infcting Bermudagrass. Phytopathology. Lancaster, 73: 341-346.

DAVIS, M.J., A.G. GILLASPIE JR. A.K. VIDAVER e R.W. HARRIS. 1984. Clavibacter; a New Genus Containing Some Phytopathoge nic Coryneform Bacteria, Including Clavibacter xyli subsp. xyli sp. nov., subsp. nov. and clavibacter xybi subsp. cyno dontis subsp. nov., Pathogens that cause Ratoon Stunting Di sease of Sugarcane and Bermusagrass Stunting Disease. Inter national Journal of Systematic Bacteriology. Lancaster, 34 (2): $107-117$. 
DHILLON, P.S., R.S. KANWAR e J.S. BEDI, 1983. Effects of moist hot air treatment on the control of GSD and productivity of sugarcane. The Indian Sugar Crops Journal. Sahibabad, 9 (2): $3-6$.

DIMOND, A.E., 1955. Pathogenesis in the wilt diseases. Annual Review of Plant Physiology. Palo Alto, $\underline{6}$ : 329-350.

DODSON, A.K., 1973. Equipamentos para tratamento tërmico desenvolvido no PLANALSUCAR. PLANALSUCAR em Notícias. (12):4.

DOUGLAS, R.A., 1981. Correlação entre a vazão de āgua e resis tência ao raquitismo da soqueira em cana-de-açūcar. Piracicaba, ESALQ/USP, 57p. (Dissertação de Mestrado).

FARRAR, L.L., 1957. A chemical test for ratoon stunting disea se of sugarcane. Phytopathology. Lancaster, 47: 10.

FIFE, J.M. e I.E. STOKES, 1959, Amino acid changes identify ra toon stunting disease. Sugar y Azucar. New York, 54:27-28.

FORBES, I.L. e K.C. LING, 1960. Praticles associated with the ratoon stunting disease of sugarcane. Sugar Journal. New Orleans, $23(2): 15$.

FORBES, I.L., R.J. STEIB e S.J.P. CHILTON, 1960. Ratoon stunting disease of sugarcane. Louisiana State University Bulletin. (532): 1-23.

GALLI, F., H. TOKESHI, P.C.T. CARVALHO, E. BALMER, H. KIMATI, C.0.N. CARDOSO e C.L. SALGADO, 1968. Manual de Fitopatologia; Doenças das plantas e seu controle. São Paulo, Ceres, $640 p$.

Gillaspie JR., A.G., J.E. IRVIne e R.L. STEERE, 1966. Ratoon 
stunting disease virus; assay technique and partial purification. Phytopathology. Lancaster, 56: 1426-1427.

GILLASPIE JR. A.G., 1970. Evidence that ratoon stunting disease of sugar cane is caused by virus and not micoplasma. phytopathology. Lancaster, 60: 1448-1450.

GILLASPIE JR, A.G., 1971. Ratoon stunting disease rirus; problems in purification. In: Proceedings of the I Meetings A merican Society of Sugar Cane Technologists', Baton Rouge, p. 52-55.

GILLASPIE JR., A.G., R.E. DAVIS e J.F. WORLEY, 1973. Diagnosis of ratoon stunting disease based on the presence of a speci fic microorganism. Plant Disease Reportes. Washington, 57 (12): $987-990$.

GILLASPIE JR., A.G., R.E. DAVIS e J.F. WORLEY, 1975. Nature of the ratoon stunting disease agent, Sugar Journal. New orleans, $38: 7-10$.

GILLASPIE JR., A.G., J.W. BLIZZARD, 1976. Some properties of the ratoon stunting disease agent of sugarcane. Sugarcane. Phatologists'Newsletter, Aiea, (15/16): 34-36.

GILLASPIE JR., A.G., R.E. DAVIS e J.F. WORLEY, 1976a. Nature of. the bacterium associated with ratoon stunting disease of su garcane. Sugarcane Pathologists Newsletter, Aiea, (15/16): $11-15$.

GILLASPIE JR., A.G., G. FLAX e H. KOIKE, 1976b. Relationship between numbers of diagnostic bacteria and injury by ratoon stunting disease in sugar cane. Plant Disease Reorter. Wasnington, $60(7)$ : 573-575. 
GILLASPIE JR. A.G. 1978a. Anantiserum to the ratoon stunting disease associated bacterium. Sugarcane Pathologists' Newsletter. Reduit, (20): 5-6.

GILLASPIE JR., A.G., 1978b. Ratoon stunting disease of sugarcane serology. Phytopathology. Lancaster, 68: 529-532.

GILLASPIE JR., A.G. e R.W. HARRIS, 1978. Screening for resistance to ratoon stunting disease-injury; the enzime - linked immunosorbent assay. Sugar y Azucar. New York, 73(6): 42 43.

GILLASPIE JR., A.G. e R.W. HARRIS, 1979. Limitations of ELISA for detection of the RSD - Associated bacterium in sugarcane and sudangrass. Sugarcane Pathologists' Newsletter. Réduit, (22): $25-28$.

GILLASPIE JR., A.G., M.J. DAVIS, R.W. HARRIS E R.H. LAWSON 1981a. Cultivation of the causal agent of ratoon stunting disease of sugarcane. Sugarcane Pathologists' Newsletter. Réduit, (26): 6-7.

GILLASPIE JR., A.G., M.J. DAVIS, R.W. HARRISER.H. LAWSON, 1981b. Isolation and pathogenicity of the ratoon stunting disease bacterium. International Sugar Journal. Bucks, 83(995): 324-326.

HARRIS, R.W. e A.G. GILLASPIE JR., 1978. Immunofluorescent di agnosis of ratoon stunting disease. Plant Disease Reporter. Washingtom, 62 (3): 193-196.

HEAGLER, A.M. e B.A. CHAPMAN, 1984. An economic appraisae of the long-term returns from an investment in heat treatment of sugarcane in Louisiana. Journa? of the American socity of Sugar Cane Technologists'. Baton Rouge, 3: 43-9. 
HORFALL, J.G. e R.W. BARRATT, 1945. An improved grading system for measuring plant disease. Phytopathology. 35: 655 . (Abstra).

HORFSFALL, J.G. e E.B. COWLING, 1978. Pathometry; the measure ment of plant disease. In: HORSFALL J.C. e G.B. COWLING, ed. Plant Disease; an Advanced Treatise. New York, Academic Press, V.II, p.119-136.

HUGHES, C.G. e D.R.L. STEINDL, 1985. Ratoon stunting disease of sugarcane. Technical Communication Queensland Bureau of Sugar Experiment Stations. Brisbane, 2: 54.

HUGHES, C.G., 1956. Disease investigations; ratoon stunting disease. Annual Report - Queensland Bureau of Sugar Experiment Stations. Brisbane, (56): 81-84.

HUGHES, C.G. e D.R.L. STEINDL, 1956. Some further developments in the study of ratoon stunting disease in Queensland. In: Proceedings of the IX Congress - International Society of Sugar Cane Technologists'. New Delhi, p.1012-1022.

HUGHES, C.G., 1958. Disease investigations; ratoon stunting disease. Annual Report - Queensland Bureau of Sugar Experiment Stations. Brisbane, (58): 68-95.

HUGHES, C.G. 1960. Disease investigations; ratoon stunting disease. Annual Report - Queensland Bureau of Sugar Experiment Stations. Brisbane, (60): 82-83.

IRVINE, J.E., 1975. Factors affecting the expression of juvenile symptons of the ratoon stunting disease. In: Proceedings of the IV Meetings - American Society of Sugar Cane. Technologists', Baton Rouge, p.l09-113. 
KAO, J. e K.E. DAMANN JR., 1978. Microcolonies of the bacterium associated with ratoon stunting disease found in sugarcane xylem matrix. Phytopathology. Lancaster, 68: 545-551.

KAO, J. e K.E. DAMANN JR., 1980. In situ localization and morphology of the bacterium associated with ratoon stunting disease of sugarcane. Canadian Journal of Botany. Ottawa, $\underline{58}(3): 310-315$.

KAO, J., E.W. BLAKENEY, M.A. GERENCSER e K.E. DAMANN JR. 1980. Cell wall composition, percent C.G. in the DNA and serotyping of the bacterium associated with ratoon stunting disease of sugarcane. Phytopathology. St. Paul, 70: 568.

KAMIUNTEN, H. e S. WAKIMOTO, 1976. Coryneform bacteria found xylem of the ratoon stunting disease sugarcane. Annuals of the Phytopathological Society of Japan. Tokyo, 42(4): $500-$ 503 .

KHURANA, S.M.P., 1972. Cusal organisms of RSD. Sugar__ Cane Pathologists' Newsletter. Durban (8): 15 .

LARGE, E.C., 1986. Meausuring plant disease. Annual Review of Phytopathology. Palo Alto, 4: 9-28.

LIAO, C.H. e T.A. CHEN, 1981. Isolation culture and Pathogeni. city to sudam grass of a Corynobacterium associated with ra toon stunting of sugar cane and with bermuda grass. Phytopathology. St. Paul, 71: 1303-1306.

LIU, L.J., 1978. Association of a small coryform bacterium with RSD in Puert Rico. Sugarcane Pathologists' Newsletter. Redint, (20):4.

LIU, L.J., A. CORTES-MONILLOR, K. MARAMORROSCH; H. HIRUMI, J. 
E. PEREZ e J. BIRD, 1974. Isolation of an organism resembling xanthomonas vasculorum from sugarcane. affected by ratoon stunting disease. In: Proceedings of the $X V$ Congress

- International Society of Sugar Cane Technologists', Durban, p. 234-240.

LOUSTALOT, A.J., 1945. Influence of soil moisture condutions on apparent photosynthesis and transpiration of pecan trees. Journal Agricultural Research. 71: 519-532.

LUDWING, R.A., 1952. Studies on the physiology of hadromy cotiledony wilting in the tomato plant. Technical BulletinMac-Donald College Magill University. Montreal, (20): 1-38.

MICKNNEY, H.H. 1923. Influence ov soil temperature and moistu re on infection of wheat seedlings by Helminsthosporim sativum. Journal Agricultural Research. 26: 195-218.

MARAMOROSCH, K., B. PLAVSIC - BANJAC, J. BIRD e L.J. LIU. 1973, Electron microscopy of ratoon stunted sugar cane; microorga nisms in xylem. Phytopathologische Zeitschript. Berlim, 77: $270-273$.

MASUDA, Y., 1984. Controle de raquitismo da soqueira. Alcool. \& Açūcar. São Paulo, 4 : 38-40.

MATSUOKA, S., 1971a. Elephant-grass, an indicator plant for ratoon stunting virus of sugarcane. Plant Protection Bulle. tin FA0. Rome, $9(5): 110-115$.

MATSUOKA, S., 1971b. Incidēncia do vírus do raquitismo da soqueira em canas provenientes de material propagativo tratado termicamente. Revista da Sociedade Brasileira de Fitopa tologia. Mossoró, 4: 63-64. 
MATSUOKA, S.; 1972a. Raquitismo da soqueira da cana-de-açūcar; diagnose da moléstia e estudos sobre seu agente causal. Pi racicaba, ESALQ/USP, 77p. (Tese de Doutoramento).

MATSUOKA, S., 1972b. Ratoon stunting disease diagnosis with elephant-grass as um indicador plant. Suqarcane Patholoqists' Newsletter. Sydney (8): 10-11.

MATSUOKA, S., 1975. Disseminação e controle do rquitismo da: so queira da cana-de-açūcar. Suma Phytopatologica. Piracicaba, I (4): 245-257.

MATSUOKA. S., 1976. Recuperação da produtividade de variedades de cana-de-açūcar pelo tratamento térmico de toletes. Brasil Açucareiro. Rio de Janeiro, 87(5): 20-24.

MATSUOKA. S., 1980. Microplots for screening sugarcane varieties for tolerance to ratoon stunting disease. In: Proceedings of the XVII Congress-International Society of sugar. Cane Technologists'; Manila, p. 1628-1638.

MATSUOKA, S. e M.M. AQUILLERA, 1981. Efeito aditivo de nematóides e raquitismo da soqueira sobre a produção de algumas variedades de cana-de-açūcar. In: Anais do II Congresso Nä cional da Sociedade de Técnicos Açucareiros do Brasil, Rio de Janeiro, V-2, p.409-420.

MATSUOKA, S., 1983. Raquitismo da soqueira; longevidade do efeito do tratamento térmico. In: Resumos dos Trabalhos do. VI Congresso Paulista de Fitopatologia, Araras, p-39.

MATSUOKA, S., 1984. Longevidade do efeito do tratamento témico em canas infectadas pelo rquitismo da soqueira. In: Anais do III Congresso Naciona da STAB, São Paulo, p.244-249. 
NAYIAGER, M.P., R.A. OELLERMANN e G. ROTH, 1980. The isolation culture e morphology of the bactéria associated with ratoon stunting disease. Phytopathologische Zeitschrift. Berlin, 99: $273-281$.

ORGOMA, G.I.B., 1981. The effect of hot - water treatment on sugarcane germination. Sugarcane Pathologists' Newsletter. Réduit, (27): $3-6$.

PEMBERTON, C.E. e L.J. CHARPENTER, 1959. Insect vectors of su garcane virus disease. In: WILLIANS, J.R., J.R. MERCALFE, R.W. MUNGOMERS e R. MATHEUS, ed. Pests of Sugar Cane. Amsterdam, Elservier, p.411-425.

PINAZZA, A.H., 1985. A pesquisa canavieira e as produtividades agricolas. Internotas; Atividades do PLANALSUCAR em Destaque. Piracicaba, (53): 8 .

PLAVSIC - BANJAC, B. e K. MARAMOROSCH, 1972. Electron micros* copy of the $x y l e m$ of ratoon stunted sugarcane. Phytopathology. Lancaster, 62: 498-499.

RICAUD, C., 1974. Problems in the diagnosis of ratoon stunting di.sease. In: Proceedings of the XV Congress - Internationa? Society of Sugar Cane Technologists', Duban, p. 241-248.

RICAUD, C., S. SULLIVAN e J.C. AUTREY, 1976. Presence of the RSD - Associated bacterium in Mauritius. Sugarcane Pathologists'. Newsletter. Aiea, (17): 37-39.

RICHARDSON, S.R., 1978. An improved method of xylem-sap extraction using positive pressure for the rapid oiagnosis of ratoon stunting disease. Sugarcane Patrologists' Newsletter. Rēduit, (21): 17-18. 
RISCHI, H. e P. NATH, 1978. Association of the coryneform bacterium with ratoon stunting disease of sugarcane. Sugarcane Pathologists' Newsletter.. Réduit, (20): 9-10.

ROSSLER, L.A., 1974. The effects of ratoon stunting disease on three sugarcane varieties under diferent irrigation regimes. In: Proceedings of the XV Congress - International Society of Sugar Cane Technologists', Durban, p. 250-257.

ROTH, G. e C. WHITEHEAD, 1965. Virus disease sugarcane. The south African Sugar Journal. Durban, 49: 675-683.

SAALTING, G.J. e A.E. DIMOND, 1964, 1964. Nature of plugging material in xylem and its relation to rate of water flow in Fusarium-infected tomato stems. Phytopathology. Lancaster, 54: $1137-1140$.

SAXEN, Y.R., K. SINGH, U.S. SHUKLA, H.P. PANDE E V.K. MADAN., 1981. Biochemical studies on disease of sugarcane. IV Effect of sulphur applicatior on the roots of ratoon stunting disease - affected sugarcane. Sugarcane Pathologists News. letter. Réduit, (26): 3-5.

SCHEFFER, R.P. e J.C. WALKER, 1953. The physiology of Fusarium wilt of tomato. Phytopathology. Lancaster, 43: 116-125.

SCHEXNAYDER, C.A., 1956. The effect of stunting disease of sugarcane on yield of cane and sugar in Louisiana, and the use of heat treatment for control. The sugar Bulletin. New Orleans, $34(22): 349-355$.

SHUKLA, U.S., K. SINGH, V.K. MADAN E V.R. SAXENA, 1979. Effect of moist hot-air-treatment on germination and actinity in RSD affected sugarcane buds. Sugar-Cane Pathologists' Newsletter. Réduit, (23): 21-22. 
STEIB, R.J. e S.J.P. CHILTON., 1956. Recent studies conducted on the ratoon stunting disease of sugarcane in Louisiana. The Sugar Bulletin. New Orleans, 34: 328-243.

STEIB. R.J., L.L. FARRAR, I.L. FORBERS e S.P.P. SHILTON., 1956. occurrence of the ratoon stunting disease in Louisiana and its control by use of hot-air treatment. The Sugar Bulletin. New Orleans, 34: 302-306.

STEIB, R.J. e I.L. FORBES, 1957. Johnson grass an corn a carriers of the virus of ratoon stunting disease surgarcane. The Sugar Bulletin. New Orleans, 35: 375 .

STEIB, R.J. e S.J.P. CHILTON, 1968. Ratoon stunting disease can and must be controlled in Louisiana. The Sugar Bulletin. New Orleans, 46 (21): 5-7.

STEIB, R.J.e D.M. TANTERA, 1970. Studies to determine the effect of tetracycline antibiotic on the ratoon stunting dise ase (RSD) of sugarcane. Tlie Sugar Bulletin. News Orleans, 48: $217-219$.

STEIB, R.J: e D.M. CIFUENTES, 1976. Control of RSD of sugarcane by use of aerated steam. Sugar Jounal. New orleans, 39: $20-23$.

STEINDL, D.R.L., 1950. Ratoon stunting disease. In: Proceedings of the VII Congress International Society of Sugar Cane Techno logists'. Brisbane, p. 457-465.

STEINDL, D.R.L. e C.G. HUGHES, 1953. Ratoon stunting disease. The Cane Growers' Quartely Bulletin. Brisbane, 16: 79-95.

STEINDL, D.R.L., 1961. Ratoon stunting disease. In: MARTIN, J.P., E.V. ABBOTT e C.G. HUGHES, ed. Sugar Cane Disease of 
the World. Amsterdam, Elsevier, V.l. p. 433-459.

STEINDL, D.R.L., 1974. Ratoon stunting disease history, distribuition and control. In: Proceedings of the XV Congress. International Society of Sugar Cane Technologists', Durban, p. $210-212$.

STEINDL, D.R.L. e D.S. TEAKLE, 1974. Recent developments in the identification of ratoon stunting disease. In: Proceedings of the 41 Conference - Queensland Society of Sugar Cane Techno. logists', Brisbane, p.101:104.

STEINDL, D.R.L., 1976. Pathology research development; New method of identifyng ratoon stunting disease. The Cane Gro. wes' Quartely Bulletin. Brisbane, 39(4): 130-131.

SUD0, S., 1980. Bactērias associadas ao raquitismo das soquei ras da cana-de-açūcar (Saccharum spp) e avaliação do capim elefante (Pemisetum purpurim schum) como indicadora. Piracicaba, ESALQ/USP, 86p. (Dissertação de Mestrado).

SUTCLIffe, J.F., 1980. As plantas e a āgua. São Paulo, Ed. U niversidade de São Paulo, $126 p$.

TEAKLE, D.S., P.M. SMITH e D.R.L. STEINDL, 1973. Association of a small corymeform bacterium with the ratoon stunting dise-. ase of sugarcane. Australian Journal of Agricultural Research. East Melbourne, 24: 869-874.

TEAKLE, D.S., 1974. The causal agent of sugarcane ratoon stun ting disease (RSD). In: Proceedings of the XV Congress - In ternational Society of Sugar Technologists', Durban, p.225233.

TEAKLE, D.S., P.M. SMITH e D.R.L. STEINDL, 1975. Ratoon stun 
ting disease of sugarcane: possible correlation of resistance with vascular anatony. Phytopathology. Lancaster, 65: 138141 .

TEAKLE, D.S., J.M. APPLETON e D.R.L. STEINDL, 1978. An anatomical basis for resistance of sugarcane to ratoon stunting disease. Physiological Plant Pathology. New York, 12: 8391 .

THOMPSON, G.M., 1960. Cane disease; Ratoon stunting disease. Cane Growers' Quarterley Bulletin. Brisbane, 16: 79-95.

THOMPSON, G.M., 1968. Ratoon stunting disease and drought a disastrous combination. The South African Sugar Journal.. Durban, 52: 201-203.

TOKESHI, H., A. SANGUINO e F. AKIBA, 1974, $x$. albilineans, pro vāvel agente causal do raquitismo da soqueira e escaldadura de cana-de-açūcar. Brasil Açucareiro. Rio de Janeiro, 84 (6) $28-40$.

TOKESHI, H., 1980. Doenças da cana-de-açūcar. In: GALLI, F; P.C.T. CARVALHO; E. BALMER; H. KIMATI; C.O.N. CARDOSO; C.L. SALGADO; T.L. KRUGNER; E.J.B.N. CARDOSO e A.B. FILHO, Manu al de Fitopatologia; doenças das plantas cultivadas. 2.ed. São Paulo, Ceres, V.2, p. 141-206.

TODD, E., 1960. The ratoon stunting disease of sugar cane and its control in Florida. Crops Research - U.S. Department of Agriculture Agricultural Research Service. Washington, (34$12): 1-7$.

TUITE, J. 1969. Plant Pathological Methods; Fungi and Bacteria. Minneapolis, Burgess, $239 p$. 
VAADIA, Y., F.C. RANEY e R.M. HAGAN, 1961. Plant water deficits and physiological process. Annual Review of Phytopathology. Palo Alto, 12: 265-292.

VALARINI, P.J., 1978. Avaliação da resistēncia ao raquitismo da soqueira pelo método da vazão de āgua em colmos de cana-de-açūcar. Piracicaba, ESALQ/USP, 78p. (Dissertação de Mestrado).

VALARINI, P.J. e H. TOKESHI, 1980. Factores that interfer in evaluation of ratoon stunting disease resistance by water flow in sugarcane stalks I. In: Proceedings of the XVII Congress-International Society of Sugar Cane Tecnologists, Manila, p.1612-1627.

WAGGNONER, P.E. e A.E, DIMOND, 1954. Resuction in Water flow by myceli in vessels. American Journal of Botany. Lancaster, 4l: 637-640.

WEAVER, L., D.S. TEAKLE e A.C. HAYWARD, 1977. Ultrastuctural stlidies on the bacterium associated with ratoon stunting di sease ov sugar cane. Australian Journal of Agricultural Re search. Melbourne, 28: 843-852.

WEHLBURG, C., 1956. Ratoon stunting disease in Cuba. Sugar. New Iork, 51: 27-29.

WISMER, C.A. e R. URATA, 1967. Ratoon stunting disease. Annual. Report - Hawaitan Planters' Association. Honolulu, n.37.

WISMER, C.A., 1971. A sugarcane clone apparently immunne to RSD. Sugarcane Pathologists' Newsletter. Sydney, (6): 46 .

WORLEY, J.F. e A.G. GILLASPIE JR., 1975. Electron microscopy in situ of the bacterium associated with ratoon stunting di sease in sudangrass. Phytopathology. Lancaster. 65:287-295. 
.111

A $P-E N D{ }_{-}{ }_{-} C_{-}{ }_{-} S$ 


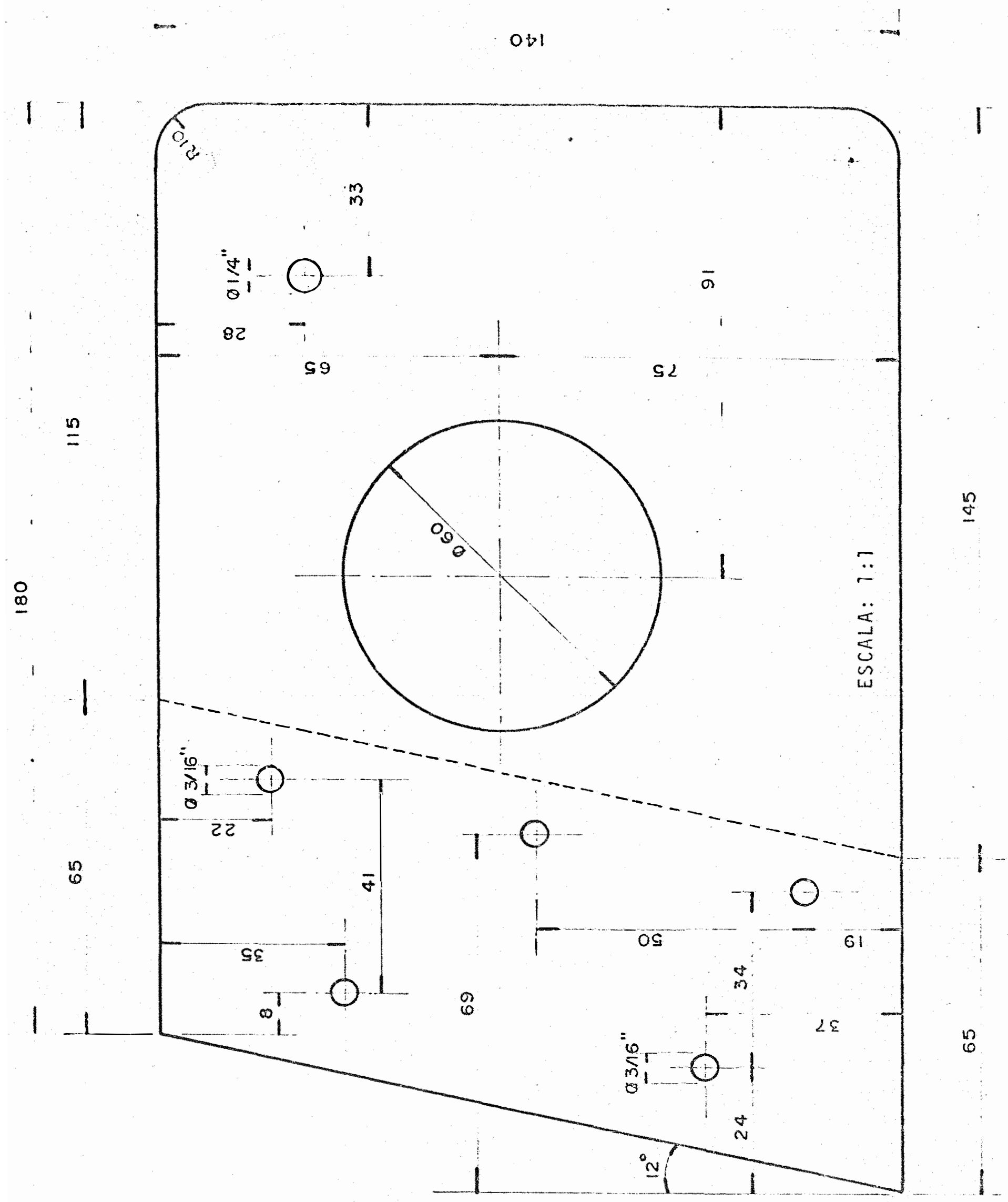

Apëndice 1. Molde da lämina de ferro galvanizado para fabricação da guilhotina 


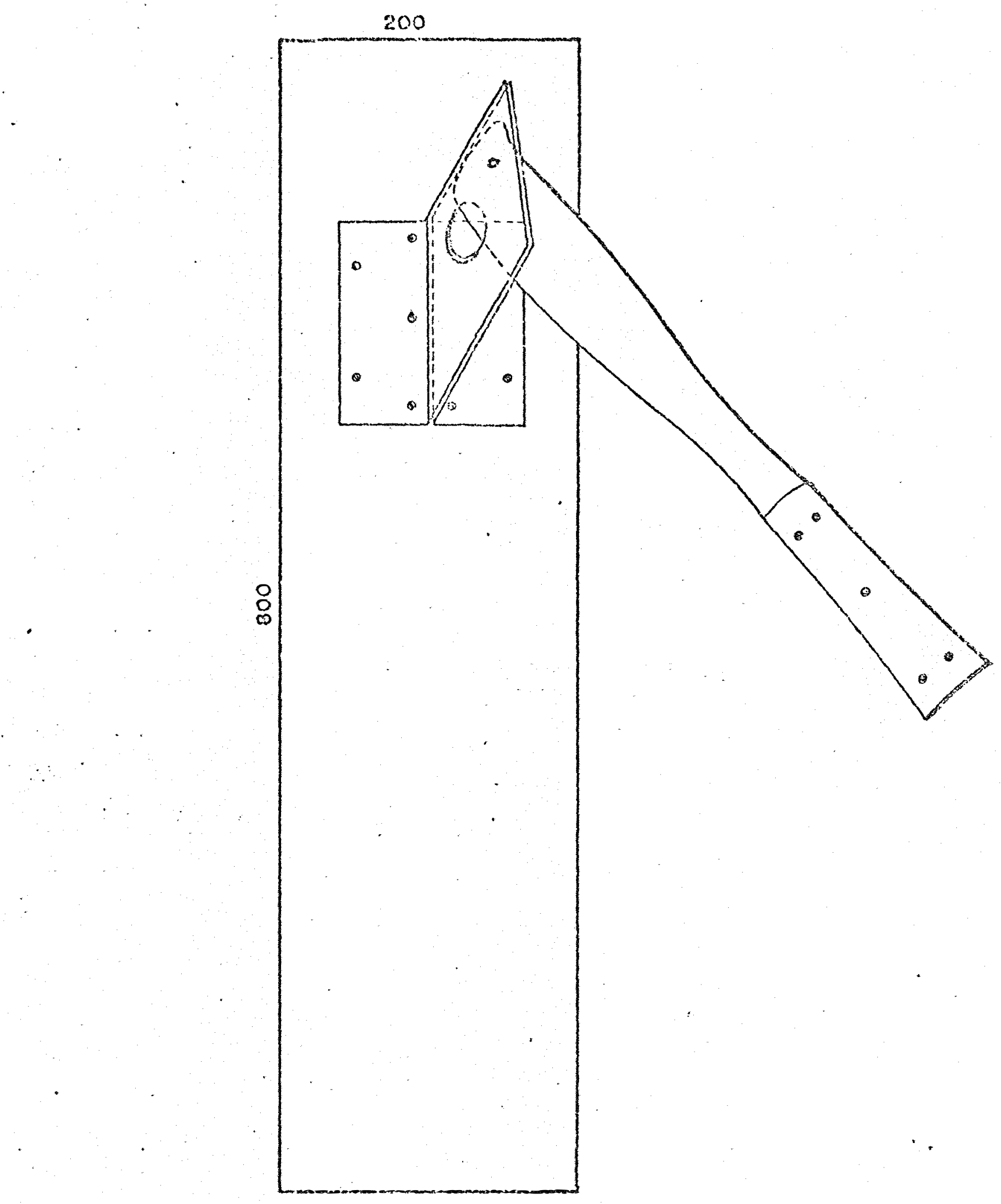

Apēndice 2. Desenho da guilhotina usada para o corte transversal de colmos de cana-de-açücar. 

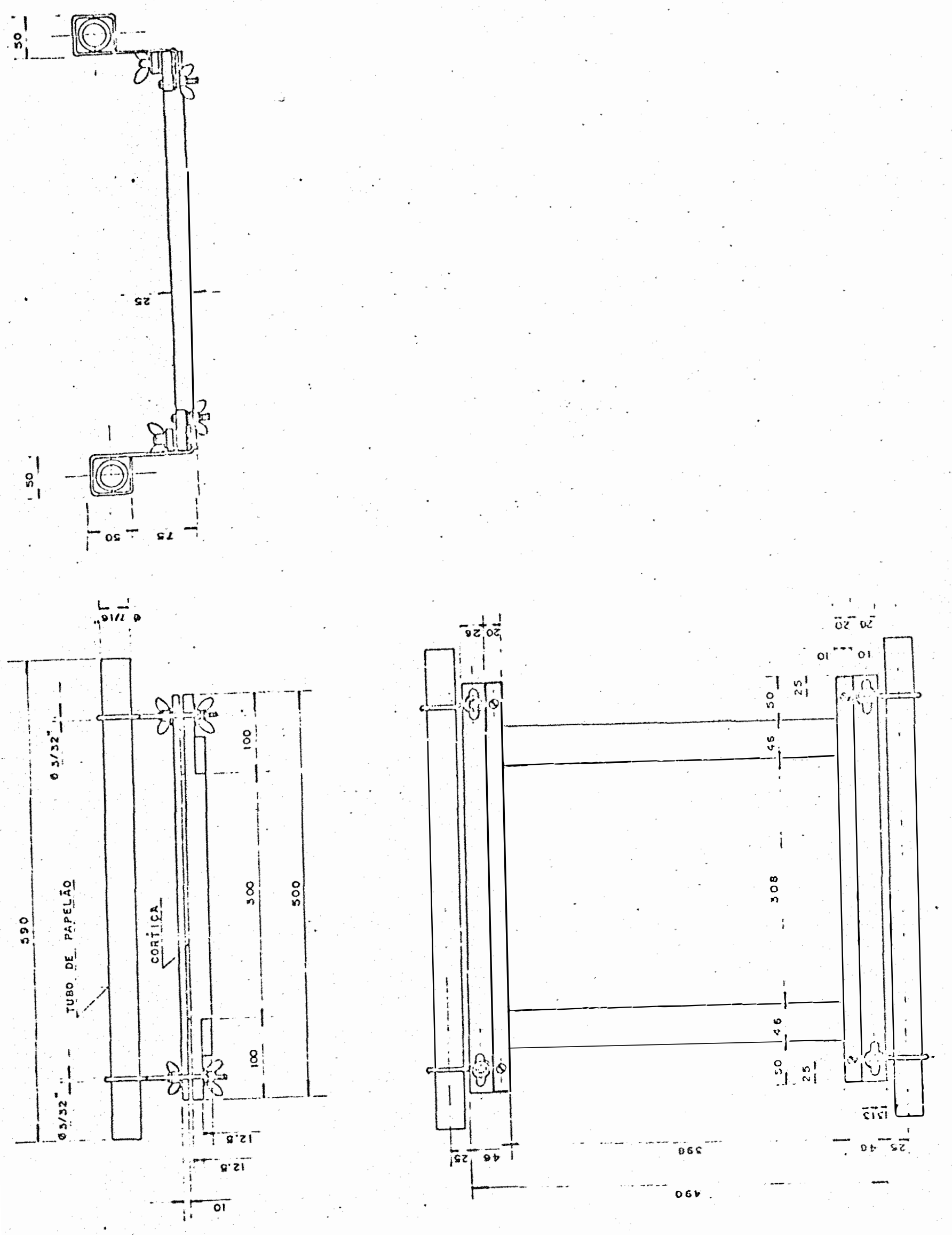

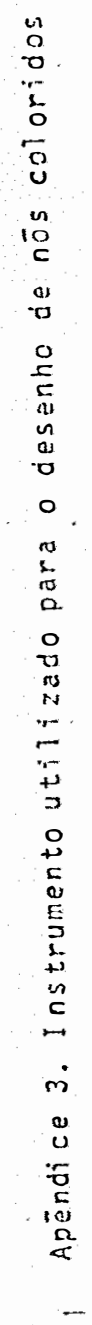




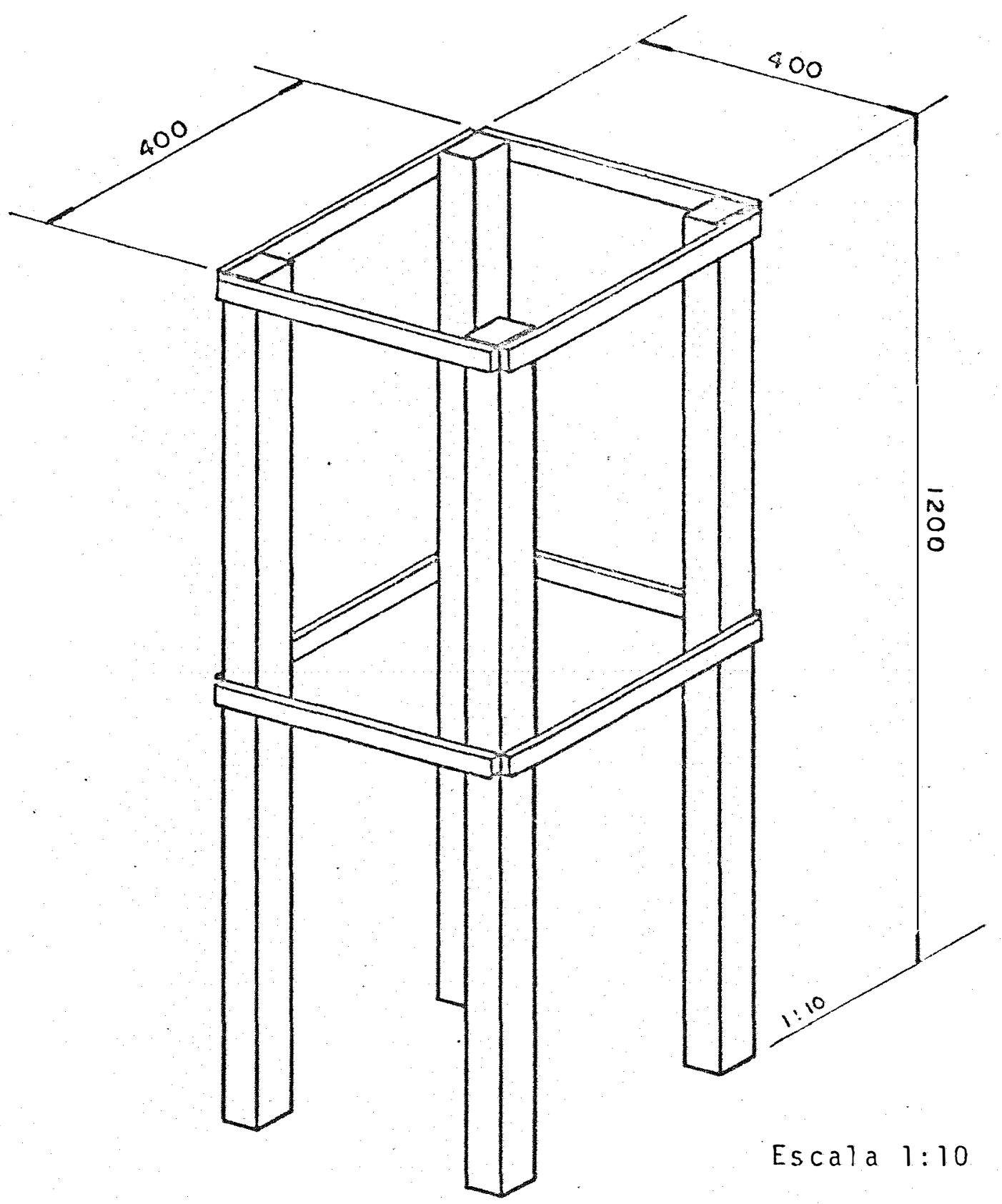

Apêndice 4. Desenho do suporte de madeira utilizado para amparar colmos de cana-de-açūcar 


\section{ESCOLA SUPERIOR DE AGRICULTURA "LUIZ DE QUEIRO}

DEPARTAMENTO DE FISICA E METEOROLOGIA

$\begin{array}{ll}\text { APENDICE } 5 \text { - DADOS METEOROLOGICOS } & \text { MES - MarçO } \\ \text { ANO } & 1984\end{array}$

\begin{tabular}{|c|c|c|c|c|c|c|c|c|}
\hline Dia & $\begin{array}{l}\text { Radiação } \\
\text { Global } 2 \text {,Dia } \\
\text { Cal/cm }\end{array}$ & $\begin{array}{l}\text { Insolaçãão } \\
\text { Hor./áia }\end{array}$ & $\begin{array}{l}\text { Precifitação } \\
\text { mintilt. }\end{array}$ & $\begin{array}{c}\text { Umidace } \\
\text { Relativa } \\
\%\end{array}$ & $\begin{array}{l}\text { Ventos } \\
\text { rédia } \\
(\mathrm{km} / \mathrm{h})\end{array}$ & $\operatorname{Maxp}^{T}$ & $\begin{array}{l}\text { eratur } \\
\text { Minn. } \\
\text { OC }\end{array}$ & î́dia \\
\hline $\begin{array}{l}1 \\
2 \\
3 \\
4 \\
5 \\
6 \\
7 \\
8 \\
9 \\
10 \\
11 \\
12 \\
13 \\
14 \\
15 \\
16 \\
17 \\
18 \\
19 \\
20 \\
21 \\
22 \\
23 \\
24 \\
25 \\
26 \\
27 \\
28 \\
29 \\
30 \\
31\end{array}$ & $\begin{array}{l}626 \\
517 \\
662 \\
649 \\
519 \\
354 \\
516 \\
570 \\
699 \\
692 \\
675 \\
664 \\
687 \\
575 \\
553 \\
572 \\
563 \\
645 \\
482 \\
564 \\
391 \\
465 \\
609 \\
623 \\
566 \\
307 \\
311 \\
530 \\
482 \\
309 \\
563\end{array}$ & $\begin{array}{r}8.1 \\
4.6 \\
9.5 \\
8.3 \\
6.2 \\
0.5 \\
5.4 \\
6.8 \\
10.2 \\
9.6 \\
10.4 \\
9.8 \\
9.7 \\
7.7 \\
6.4 \\
8.2 \\
8.0 \\
9.8 \\
2.9 \\
7.3 \\
4.2 \\
3.8 \\
8.1 \\
9.4 \\
8.9 \\
1.1 \\
0.3 \\
6.5 \\
4.2 \\
0.4 \\
5.5\end{array}$ & $\begin{array}{c}- \\
- \\
- \\
2.0 \\
9.4 \\
5.5 \\
10.8 \\
- \\
- \\
- \\
- \\
- \\
- \\
- \\
- \\
- \\
- \\
- \\
- \\
10.5 \\
4.0 \\
- \\
- \\
- \\
- \\
- \\
- \\
2.5 \\
2.4 \\
-\end{array}$ & $\begin{array}{l}67.3 \\
75.7 \\
69.5 \\
74.0 \\
80.8 \\
81.3 \\
87.7 \\
79.9 \\
77.4 \\
66.7 \\
65.7 \\
69.5 \\
66.7 \\
73.1 \\
68.3 \\
70.9 \\
71.0 \\
69.7 \\
75.4 \\
76.2 \\
82.1 \\
74.0 \\
69.8 \\
70.0 \\
70.4 \\
76.2 \\
78.1 \\
72.8 \\
80.3 \\
76.6 \\
69.4\end{array}$ & $\begin{array}{r}6.0 \\
7.2 \\
8.2 \\
7.9 \\
6.9 \\
7.1 \\
6.0 \\
7.2 \\
6.1 \\
8.4 \\
10.6 \\
12.0 \\
17.8 \\
11.3 \\
7.8 \\
8.2 \\
7.2 \\
7.8 \\
6.4 \\
8.2 \\
11.1 \\
14.0 \\
9.4 \\
7.3 \\
7.3 \\
7.0 \\
6.7 \\
6.8 \\
10.5 \\
18.4 \\
15.7\end{array}$ & $\begin{array}{l}37.0 \\
34.9 \\
31.7 \\
35.6 \\
35.1 \\
35.2 \\
29.9 \\
29.9 \\
30.9 \\
31.6 \\
33.5 \\
33.0 \\
31.4 \\
30.2 \\
29.8 \\
31.6 \\
32.9 \\
33.6 \\
33.4 \\
29.9 \\
34.8 \\
30.6 \\
28.9 \\
31.0 \\
31.9 \\
33.1 \\
31.4 \\
27.9 \\
33.2 \\
32.2 \\
25.9\end{array}$ & $\begin{array}{l}20.6 \\
20.9 \\
18.7 \\
19.2 \\
20.0 \\
20.4 \\
20.0 \\
19.8 \\
19.2 \\
19.2 \\
21.1 \\
18.0 \\
15.6 \\
18.2 \\
17.2 \\
18.4 \\
17.0 \\
16.8 \\
17.4 \\
19.0 \\
20.8 \\
19.2 \\
17.0 \\
14.4 \\
16.7 \\
19.2 \\
20.0 \\
19.9 \\
20.6 \\
20.4 \\
17.0\end{array}$ & $\begin{array}{l}28.8 \\
27,9 \\
25.2 \\
27.4 \\
27.5 \\
27.8 \\
24.9 \\
24.8 \\
25.0 \\
23.3 \\
27.3 \\
25.5 \\
23.5 \\
24.2 \\
23.5 \\
25.0 \\
24.9 \\
25.2 \\
25.4 \\
24.4 \\
27.8 \\
24.9 \\
22.9 \\
22.7 \\
24.3 \\
26.1 \\
35.7 \\
23.9 \\
27.0 \\
26.3 \\
21.4\end{array}$ \\
\hline & & & Tota 1 & & & & & \\
\hline dia & 546 & 6.5 & $47 . ?$ & 73.3 & 9.1 & 32.0 & 18.7 & 25.3 \\
\hline
\end{tabular}


.117

ESCOLA SUPERIOR DE AGRICULTURA "LUIZ DE QUEIROZ"

DEPARTAMENTO DE FISICA E METEOROLOGIA

APENDICE 6 - DADOS METEOROLOGICOS
MES - Abril

ANO - 1984

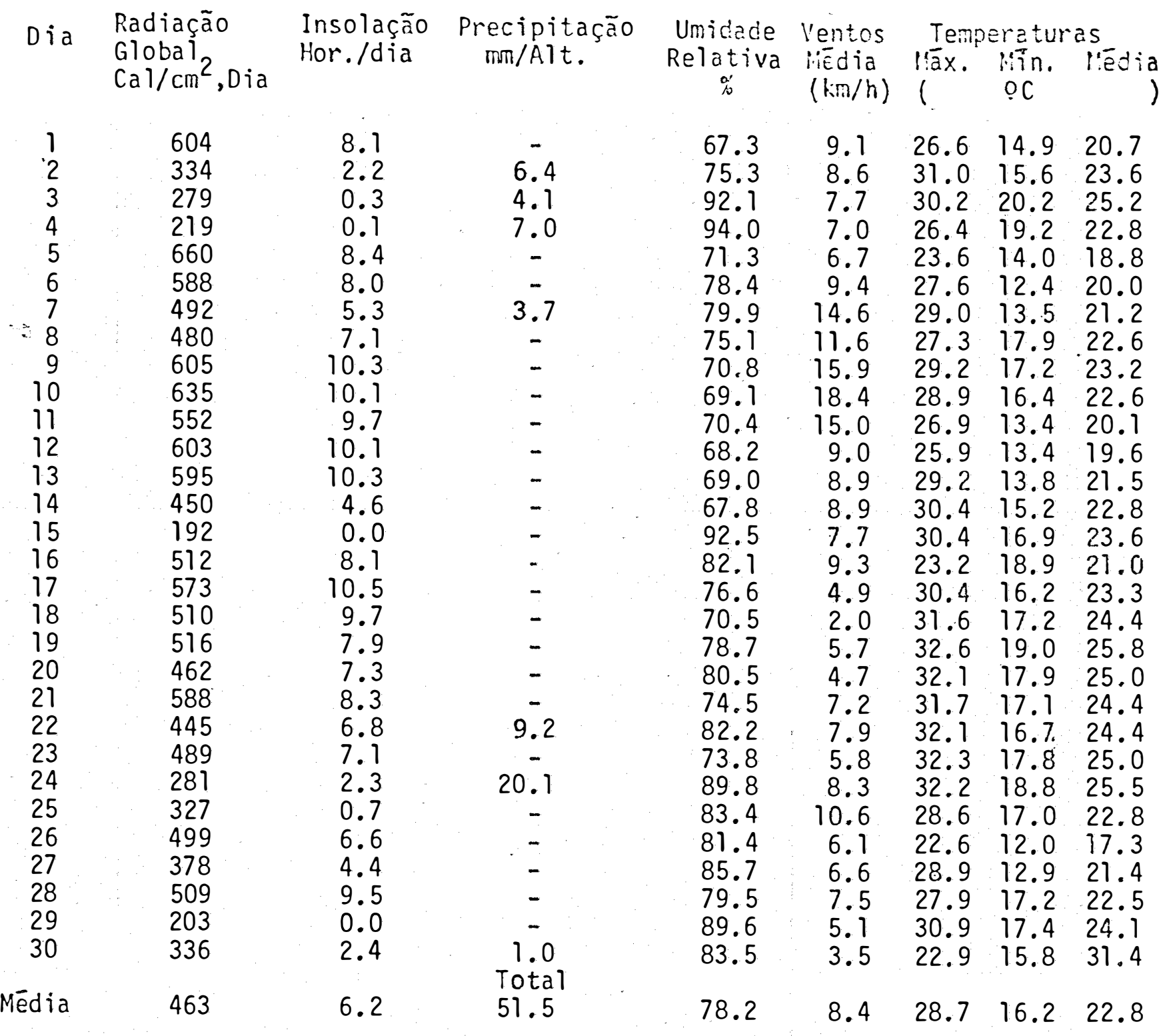




\title{
ESCOLA SUPERIOR DE AGRICULTURA "LUIZ DE QUEIROZZ" DEPARTAMENTO DE FISICA E METEOROLOGIA
}

\author{
APENDICE - 7 - DADOS METEOROLOGICOS \\ MES - - Maio \\ ANO - - 1984
}

\begin{tabular}{|c|c|c|c|c|c|c|c|c|}
\hline \multirow[b]{2}{*}{ Dia } & \multirow{2}{*}{$\begin{array}{l}\text { Radiação } \\
\text { Global } \\
\text { Cal/cm², } \\
\text { Dia. }\end{array}$} & \multirow{2}{*}{$\begin{array}{l}\text { Insol ação } \\
\text { Hor/dia }\end{array}$} & \multirow{2}{*}{$\begin{array}{c}\text { Precipitação } \\
\text { mn/Alt. }\end{array}$} & \multirow{2}{*}{$\begin{array}{l}\text { Umidade } \\
\text { Relativa } \\
\frac{\circ}{0}\end{array}$} & \multirow{2}{*}{$\begin{array}{l}\text { Ventos } \\
\text { Mídia } \\
(\mathrm{Km} / \mathrm{h})\end{array}$} & \multicolumn{3}{|c|}{ Temperatura } \\
\hline & & & & & & Máx. & $\begin{array}{l}\text { Mín. } \\
{ }^{\circ} \mathrm{C}\end{array}$ & Med. \\
\hline 1 & 301 & 2.4 & 0.5 & 87.6 & 5.8 & 28.0 & 16.2 & 22.1 \\
\hline 2 & 177 & 0.0 & 9.1 & 98.2 & 6.1 & 25.2 & 17.2 & 21.2 \\
\hline 3 & 357 & 3.0 & - & 87.2 & 5.0 & 20.6 & 15.9 & 18.2 \\
\hline 4 & 465 & 8.3 & - & 80.8 & 4.4 & 28.6 & 16.0 & 28.6 \\
\hline 5 & 507 & 9.7 & - & 77.5 & 6.4 & 30.5 & 16.8 & 23.6 \\
\hline 6 & 501 & 9.5 & - & 74.6 & 6.7 & 81.2 & 14.8 & 23.0 \\
\hline 7 & 471 & 9.4 & - & 73.9 & 7.9 & 30.2 & 15.0 & 22.6 \\
\hline 8 & 468 & 8.9 & - & 72.4 & 7.5 & 31.2 & 16.2 & 23.7 \\
\hline 9 & 476 & 9.2 & - & 70.5 & 7.9 & 32.2 & 15.9 & 24.0 \\
\hline 10 & 387 & 7.6 & - & 75.6 & 8.0 & 32.8 & 15.9 & 24.3 \\
\hline 11 & 317 & 2.1 & - & 74.1 & 6.7 & 30.9 & 3.4 & 23.1 \\
\hline 12 & 329 & 3.8 & 8.5 & 86.8 & 6.9 & 29.6 & 15.6 & 22.6 \\
\hline 13 & 245 & 3.3 & 3.2 & 94.0 & 5.5 & 28.9 & 15.6 & 22.2 \\
\hline 14 & 210 & 1.1 & 14.4 & 93.8 & 4.7 & 23.9 & 16.4 & 20.1 \\
\hline 15 & 382 & 6.2 & - & 82.0 & 6.8 & 26.2 & 17.2 & 21.7 \\
\hline 16 & 372 & 4.6 & - & 85.1 & 4.7 & 26.0 & 14.2 & 20.1 \\
\hline 17 & 410 & 5.8 & 5.1 & 86.8 & 8.3 & 25.9 & 14.8 & 20.2 \\
\hline 18 & 400 & 7.4 & 4.5 & 83.0 & 9.7 & 29.9 & 15.5 & 22.7 \\
\hline 19 & 459 & 9.7 & - & 79.1 & 6.0 & 28.3 & 15.2 & 21.7 \\
\hline 20 & 477 & 8.8 & - & 73.3 & 7.0 & 30.7 & 14.4 & 25.5 \\
\hline 21 & 481 & 9.8 & - & 69.9 & 7.7 & 31.4 & 14.2 & 22.8 \\
\hline 22 & 465 & 9.6 & - & 70.9 & 7.1 & 30.9 & 12.6 & 21.7 \\
\hline 23 & 449 & 9.7 & - & 73.0 & 8.0 & 30.2 & 11.4 & 20.8 \\
\hline 24 & 471 & 9.8 & - & 71. 3 & 8.9 & 28.9 & 11.4 & 20.1 \\
\hline 25 & 443 & 9.7 & - & 72.0 & 5.9 & 30.4 & 12.3 & 21.3 \\
\hline 26 & 449 & 8.4 & - & 73.8 & 8.0 & 30.0 & 11.8 & 20.9 \\
\hline 27. & 398 & 9.3 & - & 76.3 & 7.4 & 30.0 & 11.4 & 20.7 \\
\hline 28 & 432 & 8.5 & - & 76.7 & 8.9 & 30.0 & 11.9 & 20.9 \\
\hline 29 & 417 & 9.5 & - & 59.0 & 9.7 & 30.0 & 12.6 & 21.3 \\
\hline 30 & 470 & 0.8 & 0.6 & 86.3 & 7.4 & 30.4 & 15.2 & 22.8 \\
\hline 31 & 193 & 9.7 & - & 72.8 & 6.6 & 25.0 & 8.4 & 16.7 \\
\hline Média & 399 & 6.8 & $\begin{array}{c}\text { Total } \\
45.9\end{array}$ & 78.6 & 7.0 & 28.9 & 14.4 & 21.7 \\
\hline
\end{tabular}




\section{ESCOLA SUPERIOR DE AGRICULTURA "LUIZ DE QUEIROZ" DEPARTAMENTO DE FISICA E METEOROLOGIA}

\begin{tabular}{|c|c|c|c|c|c|c|c|c|}
\hline \multicolumn{6}{|c|}{ APENDICE 8 - DADOS METEOROLOGICOS } & \multicolumn{3}{|c|}{ MES - Junho } \\
\hline \multirow[b]{3}{*}{ Dia } & \multirow{3}{*}{$\begin{array}{l}\text { Radiação } \\
\text { Global } \\
\text { Cal/cm², } \\
\text { Dia. }\end{array}$} & \multirow{3}{*}{$\begin{array}{l}\text { Insolação } \\
\text { Hor/dia }\end{array}$} & \multirow{3}{*}{$\begin{array}{c}\text { Precipitação } \\
\text { mn/Alt. }\end{array}$} & \multirow{3}{*}{$\begin{array}{l}\text { Umidade } \\
\text { Relativa } \\
\quad \%\end{array}$} & \multirow{3}{*}{$\begin{array}{l}\text { Ventos } \\
\text { Média } \\
(\mathrm{Km} / \mathrm{h})\end{array}$} & NO - - & 1984 & \\
\hline & & & & & & \multicolumn{3}{|c|}{ Temperatura } \\
\hline & & & & & & Măx. & ${ }_{{ }^{\circ} \mathrm{C}}^{\mathrm{Min}}$ & Mêd. \\
\hline 1 & 427 & 9.4 & - & 78.9 & 9.2 & 26.0 & 9.9 & 17. \\
\hline 2 & 458 & 9.5 & - & 73.7 & 8.3 & 28.3 & 11.5 & 19.9 \\
\hline 3 & 456 & 9.7 & - & 69.7 & 8.1 & 29.1 & 11.6 & 20.3 \\
\hline 4 & 395 & 7.1 & - & 70.9 & 7.1 & 29.8 & 10.6 & 20.2 \\
\hline 5 & 426 & 9.1 & - & 66.6 & 7.8 & 28.9 & 12.4 & 20.6 \\
\hline 6 & 390 & 8.4 & - & 67.6 & 7.7 & 30.0 & 12.6 & 21.3 \\
\hline 7 & 422 & 9.6 & - & 69.2 & 8.5 & 30.4 & 12.0 & 21.2 \\
\hline 8 & 401 & 8.8 & - & 76.4 & 5.5 & 28.2 & 11.9 & 20.0 \\
\hline 9 & 369 & 6.8 & - & 68.3 & 14.1 & 26.9 & 11.0 & 18.9 \\
\hline 10 & 484 & 9.1 & - & 72.6 & 2.0 & 28.9 & 10.2 & 19.5 \\
\hline 11 & 459 & 8.6 & - & 65.8 & 8.0 & 23.2 & 4.9 & 14.0 \\
\hline 12 & 401 & 8.9 & - & 64.8 & 9.1 & 29.0 & 5.8 & 17.4 \\
\hline 13 & 402 & 8.2 & - & 73.2 & 6.9 & 30.2 & 12.2 & 21. 2 \\
\hline 14 & 291 & 2.1 & - & 82.9 & 4.5 & 28.6 & 14.0 & 21.3 \\
\hline 15 & 372 & 7.9 & - & 64.0 & 10.8 & 26.6 & 14.4 & 20.5 \\
\hline 16 & 370 & 8.9 & - & 65.2 & 7.8 & 31.3 & 12.8 & 22.1 \\
\hline 17 & 402 & 8.8 & - & 75.1 & 7.9 & 30.5 & 11.8 & 21.1 \\
\hline 18 & 389 & 9.5 & - & 70.8 & 7.2 & 27.6 & 12.9 & 20.2 \\
\hline 19 & 426 & 9.2 & - & 63.9 & 9.7 & 28.4 & 11.9 & 20.1 \\
\hline 20 & 410 & 8.7 & - & 59.9 & 8.8 & 30.4 & 10.2 & 20.3 \\
\hline 21 & 426 & 9.6 & - & 61.2 & 8.6 & 29.3 & 10.2 & 19.8 \\
\hline 22 & 427 & 9.2 & - & 60.5 & 9.0 & 29.4 & 11.0 & 20.2 \\
\hline 23 & 408 & 9.3 & - & 61.3 & 7.5 & 29.9 & 9.2 & 19.6 \\
\hline 24 & 426 & 8.4 & - & 63.0 & 8.3 & 29.0 & 8.6 & 18.8 \\
\hline 25 & 319 & 7.8 & - & 91.2 & 8.8 & 29.0 & 8.8 & 18.9 \\
\hline 26 & 457 & 9.3 & - & 51. & 11.7 & 30.0 & 10.9 & 20.4 \\
\hline 27 & 390 & 8.0 & - & 75.4 & 9.7 & 30.4 & 11.9 & 21.1 \\
\hline 28 & 359 & 4.1 & - & 80 . & 8.4 & 26.9 & 8.4 & 17.6 \\
\hline 29 & 474 & 9.1 & - & 77. & 9.8 & 21.6 & 7.4 & 14.5 \\
\hline 30 & 426 & 9.0 & - & 78.8 & 6.8 & 22.3 & 6.8 & 14.6 \\
\hline Média & 408 & 8.4 & & 70.0 & 8.2 & 28.3 & 10.5 & 19.4 \\
\hline
\end{tabular}




\title{
.ESCOLA SUPERIOR DE AGRICULTURA "LUIZ DE QUEIROZ"
}

DEPARTAMENTO DE FISICA E METEOROLOGIA

\author{
APENNDICE 9 - DADOS METEOROLOGICOS \\ MES - JUTho \\ ANO - 1984
}

\begin{tabular}{|c|c|c|c|c|c|c|c|c|}
\hline \multirow[b]{2}{*}{ Dia } & \multirow{2}{*}{$\begin{array}{l}\text { Radiação } \\
\text { Global } \\
\text { Cal/cm², } \\
\text { Dia }\end{array}$} & \multirow{2}{*}{$\begin{array}{l}\text { Insolação } \\
\text { Hort/Dia }\end{array}$} & \multirow{2}{*}{$\begin{array}{c}\text { Precipitação } \\
\text { mon/Ait }\end{array}$} & \multirow{2}{*}{$\begin{array}{l}\text { Umidade } \\
\text { Relativa } \\
\frac{0}{0}\end{array}$} & \multirow{2}{*}{$\begin{array}{l}\text { Ventos } \\
\text { Média } \\
(\mathrm{km} / \mathrm{h})\end{array}$} & \multicolumn{3}{|c|}{ Tenperatura } \\
\hline & & & & & & Máx. & Mín. & Méd. \\
\hline 1 & 485 & 5.2 & - & 74.4 & 9.9 & 25.2 & 7.8 & 16.5 \\
\hline 2 & 435 & 7.7 & - & 70.2 & 14.0 & 26.4 & 8.4 & 17.4 \\
\hline 3 & 426 & 9.3 & - & 51.9 & 16.5 & 28.8 & 12.6 & 20.7 \\
\hline 4 & 357 & 6.0 & 0.6 & 63.0 & 11.0 & 30.0 & 13.9 & 21.9 \\
\hline 5 & 453 & 9.8 & - & 53.7 & 12.9 & 30.2 & 15.0 & 22.6 \\
\hline 6 & 448 & 9.4 & - & 54.5 & 12.8 & 31.9 & 14.6 & 23.2 \\
\hline 7 & 398 & 7.8 & - & 72.6 & 9.4 & 31.4 & 12.4 & 21.9 \\
\hline 8 & 435 & 8.8 & - & 71.2 & 7.5 & 29.4 & 12.2 & 20.8 \\
\hline 9 & 467 & 9.6 & - & 55.6 & 11.7 & 29.6 & 11.3 & 20.4 \\
\hline 10 & 459 & 9.7 & - & 58.7 & 9.2 & 28.4 & 11.2 & 19.8 \\
\hline 11 & 419 & 9.6 & - & 55.2 & 10.5 & 29.0 & 9.2 & 19.1 \\
\hline 12 & 410 & 8.0 & - & 50.2 & 9.5 & 30.2 & 10.0 & 20.1 \\
\hline 13 & 414 & 9.7 & - & 65.5 & 8.4 & 31.4 & 11.6 & 21.5 \\
\hline 14 & 250 & 0.1 & - & 80.7 & 9.1 & 30.5 & 12.5 & 21.5 \\
\hline 15 & 423 & 9.1 & - & 58.0 & 7.4 & 23.1 & 13.0 & 18.0 \\
\hline 16 & 497 & 6.8 & - & 62.1 & 5.7 & 32.0 & 13.8 & 22.9 \\
\hline 17 & 375 & 8.1 & - & 58.4 & 7.2 & 30.8 & 12.2 & 21.5 \\
\hline 18 & 406 & 7.8 & - & 56.7 & 9.2 & 31.2 & 11.8 & 21.5 \\
\hline 19 & 437 & 9.3 & - & 51.6 & 8.1 & 31.0 & 11.6 & 21.3 \\
\hline 20 & 406 & 8.0 & - & 54.2 & 7.3 & 30.6 & 11.6 & 21.1 \\
\hline 21 & 428 & 9.2 & - & 56.8 & 14.0 & 29.6 & 11.9 & 20.7 \\
\hline 22 & 310 & 3.3 & - & 75.8 & $12: 5$ & 29.6 & 10.2 & 19.9 \\
\hline 23 & 399 & 6.7 & - & 78.5 & 13.3 & 18.9 & 7.2 & 13.0 \\
\hline 24 & 495 & 9.8 & - & 71.4 & 6.2 & 20.9 & 6.9 & 13.9 \\
\hline 25 & 429 & 7.4 & - & 70.9 & 7.8 & 25.4 & 7.4 & 16.4 \\
\hline 26 & 452 & 9.2 & - & 76.2 & 10.8 & 28.9 & 9.2 & 19.0 \\
\hline 27 & $344^{\circ}$ & 5.2 & 8.3 & 76.5 & 9.0 & 24.2 & 9.8 & 17.0 \\
\hline 28 & 446 & 8.5 & - & 76.4 & 9.8 & 28.2 & 10.4 & 19.3 \\
\hline 29 & & 8.8 & - & 77.0 & 13.7 & 25.9 & 11.1 & 18.5 \\
\hline 30 & 527 & 10.0 & - & 70.2 & 6.8 & 21.9 & 8.2 & 15.0 \\
\hline 31 & 482 & 5.9 & - & 63.6 & 8.0 & 25.6 & 7.9 & 16.7 \\
\hline Edia & 420 & 7.8 & 8.9 & 64.8 & 9.9 & 28.0 & 10.8 & 19.4 \\
\hline
\end{tabular}


ESCOLA SUPERICR TE AGRICULTURA "LUIZ DE QUEIROZ"

DEPARTAMENTO DE FISICA E METECROLCGIA

APENDICE 10 - DADOS METEOROLOGICOS

Radiação Insolação Precipitação

Dia

Global

$\mathrm{Cal} / \mathrm{cm}^{2}$,

Dia

$\begin{array}{rrrrrrrrr}1 & 468 & 9.6 & - & 49.5 & 10.7 & 27.2 & 8.2 & 17.7 \\ 2 & 391 & 4.9 & 26.1 & 76.5 & 20.9 & 29.8 & 10.2 & 20.0 \\ 3 & 192 & 2.5 & 7.7 & 90.4 & 10.2 & 30.8 & 15.4 & 23.1 \\ 4 & 495 & 9.4 & - & 79.2 & 7.7 & 20.2 & 12.1 & 16.1 \\ 5 & 518 & 9.7 & - & 55.7 & 11.6 & 28.0 & 12.2 & 20.1 \\ 6 & 482 & 8.8 & - & 55.1 & 12.9 & 32.9 & 13.4 & 23.1 \\ 7 & 415 & 8.7 & - & 73.2 & 8.8 & 33.4 & 15.8 & 24.6 \\ 8 & 436 & 8.2 & - & 73.1 & 7.8 & 32.2 & 12.8 & 22.5 \\ 9 & 477 & 9.4 & - & 62.0 & 8.7 & 31.8 & 15.9 & 23.8 \\ 10 & 498 & 9.9 & - & 57.0 & 7.9 & 31.9 & 15.4 & 23.6 \\ 11 & 558 & 10.1 & - & 54.1 & 10.4 & 32.6 & 13.5 & 23.0 \\ 12 & 515 & 9.4 & - & 51.4 & 9.1 & 33.3 & 12.7 & 23.0 \\ 13 & 425 & 9.0 & - & 71.8 & 7.4 & 33.8 & 13.4 & 23.6 \\ 14 & 438 & 8.8 & - & 75.4 & 9.5 & 29.1 & 12.2 & 20.6 \\ 15 & 471 & 7.0 & - & 76.5 & 12.3 & 26.4 & 12.4 & 19.4 \\ 16 & 333 & 3.8 & - & 79.5 & 12.5 & 23.4 & 12.0 & 17.7 \\ 17 & 536 & 8.9 & - & 70.7 & 19.3 & 20.4 & 9.8 & 15.1 \\ 18 & 591 & 9.2 & - & 69.0 & 18.1 & 22.2 & 12.0 & 17.4 \\ 19 & 347 & 5.0 & 11.2 & 72.6 & 11.8 & 24.6 & 10.8 & 17.7 \\ 20 & 162 & 0.0 & 1.0 & 96.2 & 7.7 & 23.4 & 11.2 & 17.3 \\ 21 & 402 & 5.6 & 25.7 & 89.8 & 10.4 & 17.6 & 13.2 & 15.4 \\ 22 & 217 & 0.3 & 29.4 & 93.4 & 7.5 & 2.4 .5 & 13.2 & 18.8 \\ 23 & 499 & 7.7 & - & 80.9 & 5.9 & 22.1 & 15.6 & 18.8 \\ 24 & 570 & 8.3 & 3.6 & 70.8 & 10.7 & 25.8 & 12.4 & 19.1 \\ 25 & 193 & 0.0 & 6.6 & 93.0 & 12.3 & 29.4 & 13.4 & 21.4 \\ 26 & 654 & 9.5 & - & 68.6 & 12.1 & 20.1 & 6.4 & 13.2 \\ 27 & 566 & 9.3 & - & 72.8 & 8.8 & 17.2 & 2.9 & 10.0 \\ 28 & 474 & 7.2 & - & 79.0 & 12.3 & 19.9 & 4.8 & 12.3 \\ 29 & 429 & 4.5 & - & 78.6 & 10.9 & 21.9 & 7.0 & 14.4 \\ 30 & 428 & 5.9 & 0.8 & 80.1 & 8.3 & 22.4 & 11.8 & 14.7 \\ 31 & 593 & 10.2 & - & 73.3 & 7.8 & 24.2 & 11.9 & 18.0 \\ & & & \text { Tota1 } & 73.2 & 10.7 & 26.2 & 11.7 & 18.8 \\ \text { NEdia } & 444 & 7.1 & 112.1 & 73.2 & & & & \end{array}$

MÉS - Agos to

ANก - 1984
Unidade Ventos Temperaturas Relativa Média Niáx. Mín. Mín. $(\mathrm{km} / \mathrm{h})$ Nax. Nine the Relations Hor./dia molAlt. 
ESCOLA SUPERIOR DE AGRICULTURA "LUIZ DE QUEIROZ" DEPARTAMENTO DE FISICA E METEOROLOGIA

$\begin{array}{ll}\text { APENDICE } 11-\text { DADOS METEOROLOGICOS } & \text { MES - Setembro } \\ \text { ANO - } 1984\end{array}$

\begin{tabular}{|c|c|c|c|c|c|c|c|c|}
\hline & Radiação & Insolação & Precipitação & Unidade & Ventos & \multicolumn{3}{|c|}{ Temperatura } \\
\hline Dia & $\begin{array}{l}\text { Global } \\
\mathrm{Cal} / \mathrm{cm}^{2}, \\
\mathrm{Dia}\end{array}$ & Hor./dia & $\mathrm{mnn} / \mathrm{Alt}$ & $\underset{\%}{\operatorname{Relativa}}$ & $\begin{array}{l}\text { Média } \\
(\mathrm{km} / \mathrm{h})\end{array}$ & Máx. & Min. & Méd. \\
\hline 1 & 608 & 9.4 & - & 68.8 & 6.8 & 27.2 & 10.2 & 18.7 \\
\hline 2 & 577 & 9.6 & - & 61.2 & 6.9 & 26.9 & 10.4 & 18.6 \\
\hline 3 & 586 & 8.7 & - & 52.4 & 8.5 & 28.4 & 11.9 & 20.1 \\
\hline 4 & 600 & 9.9 & - & 52.6 & 7.0 & 28.9 & 10.6 & 19.7 \\
\hline 5 & 556 & 9.7 & - & 58.8 & 5.9 & 28.8 & 12.2 & 20.5 \\
\hline 6 & 402 & 5.5 & 16.4 & 78.6 & 11.7 & 30.8 & 12.2 & 21.5 \\
\hline 7 & 287 & 0.7 & 2.1 & 86.6 & 10.6 & 20.2 & 13.2 & 21.2 \\
\hline 8 & 124 & 0.0 & 22.7 & 95.9 & 7.7 & 23.9 & 15.9 & 19.9 \\
\hline 9 & 570 & 8.5 & - & 64.6 & 8.9 & 20.0 & 13.2 & 16.6 \\
\hline 10 & 654 & 10.3 & - & 67.5 & 14.9 & 23.2 & 9.4 & 16.3 \\
\hline 11 & 680 & 10.3 & - & 66.6 & 7.0 & 22.4 & 8.9 & 15.6 \\
\hline 12 & 617 & 9.5 & - & 62.8 & 7.2 & 25.2 & 8.2 & 16.7 \\
\hline 13 & 612 & 10.1 & - & 48.7 & 7.3 & 28.6 & 9.2 & 18.9 \\
\hline 14 & 573 & 9.8 & - & 62.2 & 5.0 & 29.9 & 11.6 & 20.7 \\
\hline 15 & 514 & 6.7 & - & 54.7 & 9. & 31.6 & 12.6 & 22.1 \\
\hline 16 & 360 & 4.0 & 0.4 & 79.0 & 8.3 & 31.9 & 13.2 & 22.5 \\
\hline I & 590 & 5.8 & - & 71.3 & 12. & 28.6 & 14.2 & 1. 4 \\
\hline 18 & 597 & 9.7 & - & 72.5 & 9. & 26.0 & 11.4 & 18.7 \\
\hline 19 & 543 & 8.6 & 0.9 & 64. & 18. & 29.2 & 13.4 & \\
\hline 20 & 194 & 0.6 & 25.6 & 92.9 & 9. & 24.2 & 17.9 & 23.9 \\
\hline 21 & 620 & 9.6 & - & 72.2 & 5.2 & 25.1 & 10.0 & 17.5 \\
\hline 22 & 690 & 10.8 & - & 57.2 & 7.8 & 25.8 & 9.7 & 17.7 \\
\hline 23 & 711 & 10.2 & - & 67.5 & 8.4 & 29.4 & 12.9 & 21.1 \\
\hline 22 & 645 & 8.7 & - & 73.5 & 8. & 32.4 & 15.4 & 23.9 \\
\hline 25 & 518 & 4.4 & 6.9 & 63.0 & 12. & 31.9 & 17.0 & 24.4 \\
\hline 26 & 278 & 1.1 & 12.3 & 91.5 & 8.2 & 28.6 & 17.4 & 23.0 \\
\hline 27 & 343 & 1.7 & 3.1 & 90.6 & 11.5 & 24.4 & 13.6 & 19.0 \\
\hline 28 & 693 & 9.0 & - & 62.7 & 10.7 & 21.9 & 9.9 & 15.9 \\
\hline 29 & 774 & 10.9 & - & 64.4 & 11.0 & 24.9 & 10.9 & 17.9 \\
\hline 30 & 797 & 10.6 & - & 64.4 & 11.6 & & & \\
\hline & & & Total & & & & & \\
\hline$\hat{E}$ & 543 & 7.4 & 90.4 & 68.9 & 9.3 & 27.0 & 12.3 & 9.8 \\
\hline
\end{tabular}


ESCOLA SUPERIOR DE AGRICULTURA "LUIZ DE QUEIROZ" DEPARTAMENTO DE FISICA E METEOROLOGIA

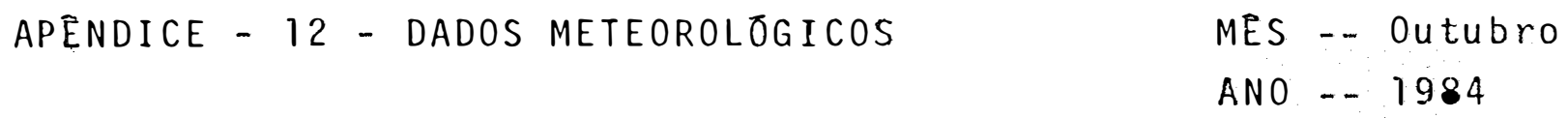

\begin{tabular}{|c|c|c|c|c|c|c|c|c|}
\hline & Radiação & Insolação & Precipitação & Unidade & Ventos & \multicolumn{3}{|c|}{ Temperatura } \\
\hline Dia & $\begin{array}{l}\text { Global } \\
\mathrm{CaI} / \mathrm{cm}^{2}, \\
\mathrm{Dia}\end{array}$ & Hor./dia & mn/Alt. & $\underset{\frac{O}{0}}{\operatorname{Re} 1_{\text {ativa }}}$ & $\begin{array}{l}\text { Nédia } \\
(\mathrm{km} / \mathrm{h})\end{array}$ & Mäx. & Min. & Méd. \\
\hline 1 & 524 & 10.3 & - & 65.7 & 7.8 & 26.2 & 10.0 & 18.1 \\
\hline 2 & 519 & 10.0 & - & 66.9 & 6.6 & 30.2 & 11.2 & 20.7 \\
\hline 3 & 493 & 10.4 & - & 58.9 & 8.5 & 31.9 & 13.8 & 22.8 \\
\hline 4 & 481 & 9.9 & - & 53.1 & 8.9 & 33.2 & 15.8 & 24.5 \\
\hline 5 & 483 & 9.3 & - & 50.7 & 9.9 & 34.4 & 17.2 & 25.8 \\
\hline 6 & 426 & 7.8 & - & 63.9 & 15.6 & 34.7 & 18.4 & 26.5 \\
\hline 7 & 533 & 9.6 & - & 76.9 & 14.5 & 34.8 & 17.6 & 26.2 \\
\hline 8 & 399 & 7.7 & - & 73.0 & 7.9 & 29.8 & 15.0 & 22.4 \\
\hline 9 & 150 & 0.0 & - & 86.1 & 7.1 & 33.2 & 17.6 & 25.4 \\
\hline 10 & 348 & 3.1 & - & 75.1 & 8.8 & 25.9 & 18.2 & \\
\hline 11 & 550 & 10.8 & - & 62.3 & 15.6 & 29.4 & 17.2 & 23.3 \\
\hline 12 & 563 & 10.1 & - & 67.2 & 10.3 & 30.1 & 13.2 & 21.6 \\
\hline 13 & 483 & 9.3 & - & 66.5 & 7.5 & 31.4 & 12.4 & 21.9 \\
\hline 14 & 393 & 10.3 & - & 60.0 & 10.2 & 33.2 & 14.9 & 4.0 \\
\hline 15 & 445 & 6.6 & - & 72.3 & 11.8 & 34.8 & 17.4 & 26.1 \\
\hline 16 & 4.57 & 6.9 & 0.4 & 73.3 & 6.7 & 30.2 & 18.4 & 24.3 \\
\hline 17 & 504 & 9.0 & 23.4 & 67.4 & 11.9 & 32.9 & 19.8 & 26.3 \\
\hline 18 & 146 & 0.0 & 3.2 & 91.3 & 11.0 & 33.2 & 19.4 & 26.3 \\
\hline 19 & 207 & 0.4 & - & 82.0 & 16.5 & 24.4 & 17.9 & 21.1 \\
\hline 20 & 574 & 10.0 & - & 75.8 & 13.7 & 21.0 & 14.2 & 17.6 \\
\hline 21 & 556 & 9.8 & - & 67.4 & 8.9 & 25.2 & 14.2 & 19.7 \\
\hline 22 & 566 & 10.5 & - & 57.4 & 8.5 & 31.2 & 15.9 & 23.5 \\
\hline 23 & 562 & 10.2 & - & 59.1 & 10.8 & 32.4 & 17.6 & \\
\hline 24 & 396 & 5.4 & - & 69.6 & 12.8 & 34.0 & 16.0 & 25.0 \\
\hline 25 & 512 & 10.8 & - & 68.5 & 13.8 & 30.2 & 17.2 & 23.7 \\
\hline 26 & 553 & 10.3 & - & 61.8 & 10.7 & 31.2 & 17.0 & 24.1 \\
\hline 27 & 570 & 11.1 & - & 60.3 & 9.0 & 31.6 & 15.9 & 23.7 \\
\hline 28 & 594 & 11.2 & - & 50.6 & 9.8 & 33.4 & 15.9 & 24.6 \\
\hline 29 & 530 & 10.0 & - & 47.2 & 8. & 34.8 & 17.4 & 26.1 \\
\hline 30 & 524 & 10.0 & - & 52.5 & 9.3 & 36.0 & 19.4 & 27.7 \\
\hline 31 & 552 & 9.9 & & 71.4 & 21.6 & 36.8 & 19.2 & 28.0 \\
\hline Mëdia & 470 & 8.4 & $\begin{array}{l}\text { Total } \\
27.0\end{array}$ & 66.2 & 10.7 & 31.3 & 16.3 & 23.8 \\
\hline
\end{tabular}

